AUTARQUIA ASSOCIADA À UNIVERSIDADE DE SÃO PAULO

Desenvolvimento de uma metodologia rápida e de baixo custo para diagnóstico da Anemia Falciforme

Elen Gonçalves dos Santos

Tese apresentada como parte dos requisitos para obtenção do Grau de Doutor em Ciências na Área de Tecnologia Nuclear - Materiais

Orientadora:

Profa. Dra. Maria Claudia França da Cunha Felinto

São Paulo 


\section{INSTITUTO DE PESQUISAS ENERGÉTICAS E NUCLEARES}

Autarquia associada à Universidade de São Paulo

Desenvolvimento de uma metodologia rápida e de baixo custo para diagnóstico da Anemia Falciforme

Elen Gonçalves dos Santos

Tese apresentada como parte dos
requisitos para obtenção do Grau de
$\begin{aligned} & \text { Doutor em Ciências na Área } \\ & \text { de Tecnologia Nuclear-Materiais }\end{aligned}$

Orientadora:

Profa. Dra. Maria Claudia França da Cunha Felinto

Versão Corrigida

Versão Original disponível no IPEN

São Paulo 
Dedico esse trabalho ao meu amado marido

Lágrimas e tormentos

Lágrimas, tormentos

Quantas desilusões

Foram tantos sofrimentos e decepções

Mas um dia o destino a tudo modificou

Minhas lágrimas secaram

Meus tormentos terminaram

Foi uma nuvem que passou

Minhas lágrimas secaram

Meus tormentos terminaram

Foi uma nuvem que passou

E hoje a minha vida é um carrossel de alegrias E como se não bastasse, estou amando de verdade Me perdoa se eu me excedo em minha euforia Mas é que agora sei o que é felicidade 
O sucesso é ir de fracasso em fracasso sem perder entusiasmo.

Winston Churchill

O mundo é um lugar perigoso de se viver, não por causa daqueles que fazem o mal, mas sim por causa daqueles que observam e deixam o mal acontecer.

Albert Einstein 


\section{AGRADECIMENTOS}

A Dra. Maria Claudia Felinto, pela oportunidade profissional, paciência, dedicação e maravilhosa jornada e amizade

Aos meus amados pais, razão de todas as minhas vitórias

À minha filha, minha vida, por me proporcionar os melhores sentimentos

A toda minha família pela compreensão, carinho e apoio

Ao Dr. Oscar Vega, pela grande ajuda e amizade

À minha sobrinha Fernanda Arthuso, amiga de todos os tempos

As minhas queridas amigas Débora Salum e Liana Nakamura pela valiosíssima amizade, grande ajuda e dedicação

Ao Everton Bonturim pela amizade e grande ajuda

Ao Felipe Albero pela ajuda e grande amizade

Ao Dr. Eduardo Sanches pelas contribuições

À Dra. Jacinete Lima e Dra. Claudia Akemi pela grande contribuição

Ao Professor Dr. Magnus Gidlund por sua imensa ajuda

Ao Professor Rômulo Ando do Instituto de Química/USP

Ao Fernando Lepre do Instituto de Química/USP, pela grande ajuda

À Professora Dra. Dalva Lúcia Araújo de Faria do Instituto de Química/USP pela grande contribuição 
Aos amigos do Instituto de Química/USP: Lucas, Cássio, Ivan e Thiago pela imensa ajuda

Ao Prof. Dr. Hermi Brito pelos ensinamentos e amizade

Ao Camilo Misura da UFABC pela ajuda

À Taciana Magrini da UFABC pela ajuda

À Dra Maria Edileuza Felinto de Brito pela ajuda e dedicação

À Juliana Ikebe do CQMA/IPEN pela ajuda

Aos meus amigos do CQMA, são muitos os nomes, obrigada pela maravilhosa jornada

Aos colegas da CPG pela enorme ajuda

Ao Hospital Universitário da USP, pela parceria

Ao Instituto de Pesquisas Energéticas e Nucleares, pela oportunidade de desenvolver este trabalho

À CNEN, pela concessão de recursos financeiros 


\title{
DESENVOLVIMENTO DE UMA METODOLOGIA RÁPIDA E DE BAIXO CUSTO PARA DIAGNÓSTICO DA ANEMIA FALCIFORME
}

\section{ELEN GONÇALVES DOS SANTOS}

\begin{abstract}
RESUMO
Segundo estimativas da Organização Mundial de Saúde (OMS) no Brasil nascem 3.500 crianças com anemia falciforme a cada ano e $20 \%$ delas não conseguem atingir os cinco anos de idade devido às complicações diretas causadas pela doença. A anemia falciforme é uma doença do grupo das hemoglobinopatias extremamente comum e é causada por uma alteração molecular no cromossoma 11, quando ocorre a substituição do ácido glutâmico pelo aminoácido valina, na posição 6 da cadeia da $\beta$ globina. No Brasil acredita-se que a anemia falciforme seja a doença hereditária que mais prevalece, sendo assim, ela é considerada um problema de saúde pública. Alguns estudos apontaram a existência de uma prevalência de aproximadamente 4 a $5 \%$ em recém-nascidos portadores da doença e sua maior incidência ocorre no norte e nordeste, regiões brasileiras mais pobres e com maior miscigenação das populações. É urgente a necessidade do desenvolvimento de um diagnóstico viável e acessível a tais áreas, pois existe o reconhecimento pela própria OMS de tal prioridade e que levou o Brasil a criar uma Portaria em 2005 e um Decreto em 2008 que instituem atenção integral aos portadores da doença falciforme. Portanto, foi desenvolvido neste trabalho um método de triagem para a detecção de anemia falciforme, que usou uma tecnologia atual conhecida como point-of-care. Para isso foi utilizado uma gota de sangue em meio tamponado com detergente comercial Limpol® para lisar as hemácias e o hidrossulfito de sódio para reduzir a hemoglobina $\mathrm{S}$ e esta foi detectada em papel de cromatografia. $\mathrm{O}$ método foi desenvolvido com eficácia, pois foi proposta a substituição da saponina (reagente caro) por detergente comercial Limpol® e do hidrossulfito de sódio (reagente caro) por tiossulfato de sódio, tornando o custo do kit desenvolvido muito baixo.
\end{abstract}


Portanto, sob quaisquer condições adversas e em qualquer região que necessite da triagem diagnóstica populacional, principalmente nas comunidades carentes e de difícil acesso, será possível levar uma solução simples a campo para a execução de um diagnóstico rápido e sem aumento do ônus para o sistema de saúde público brasileiro, consolidando os direitos adquiridos dos indivíduos, mas que não abrangem àqueles que mais necessitam. 


\title{
DEVELOPMENT OF A RAPID AND INEXPENSIVE METHOD FOR DIAGNOSIS OF SICKLE CELL DISEASE
}

\author{
ELEN GONÇALVES DOS SANTOS
}

\begin{abstract}
According to estimates from the World Health Organization (WHO), every year are born around 3.500 children with sickle cell anemia (SCA) in Brazil and 20\% of them won't reach five years old because of complications directly related to the disease. The SCA is a disease of the hemoglobinopathies group extremely common and is caused by a molecular alteration in the chromosome 11, when occurs the replacement from the acid glutamic acid by amino acid valine in the chain of position 6 of the $\beta$ globin. In Brazil is believed that the SCA is the hereditary disease that prevails more being considered as a public health problem. Some studies have indicated that exist prevalence in approximately $4-5 \%$ of this disease in newborns and the greatest incidence there is mainly in north and northeast, regions with bigger miscegenation from population. Is urgent the necessity in to develop viable accessible diagnostic for those areas whereas it was recognized as a priority by the WHO leading Brazil to create an Ordinance in 2005 and a Decree in 2008 establishing total care to the people with sickle cell disease. Therefore, was developed in this work a screening method to detect the sickle cell anemia, which used a technology known as point-of-care. Was created an alternative method to substitute one international kit which has high cost for the adequation according with of economic Public Health conditions from Brazil. For this a drop of blood in buffered medium with liquid detergent Limpol®, to lyse RBC and the (tiossulfato de sódio) to reduce the RBC S which was detected in simple celulose paper. The method was developed with efficiency, on this account the substitution of saponina (expensive reagent) by liquid detergent Limpol® and (hidrossulfitob de sodio) (expensive reagent) by (tiossulfato de sódio) was successful making the cost of developed kit cheaper. Therefore in any population with adverse conditions or region
\end{abstract}


where there are needs, mainly in poor communities with difficult acces, will be possible to lead a simple solution at field to execution by a quickly diagnostic without increasing of charges to health public brazilian system, consolidating acquired rights to individuals that not are reached by those needs yet. 


\section{SUMÁRIO}

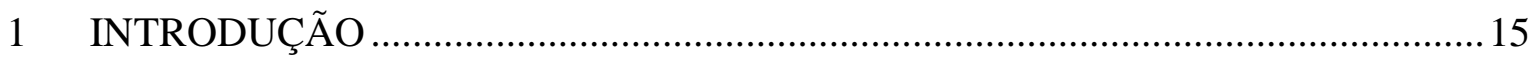

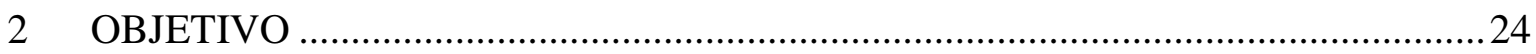

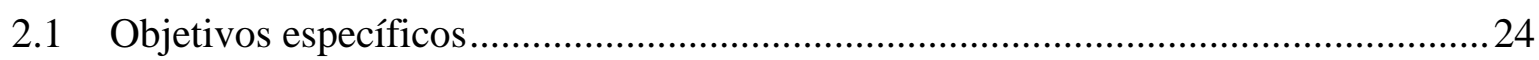

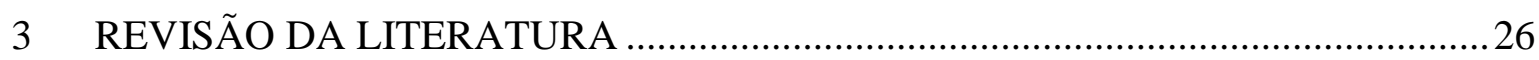

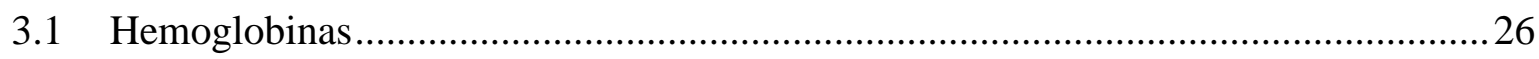

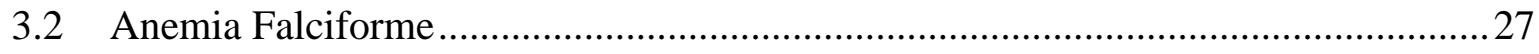

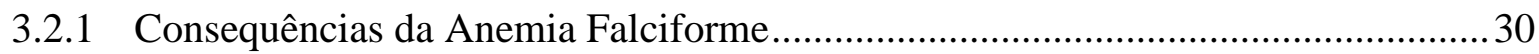

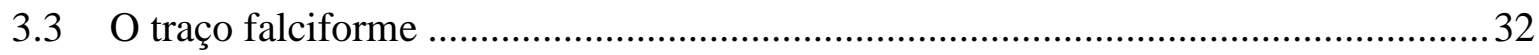

3.4 Prevalência da anemia falciforme nos centros de hemoterapia.................................33

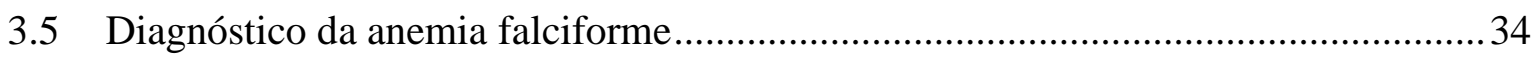

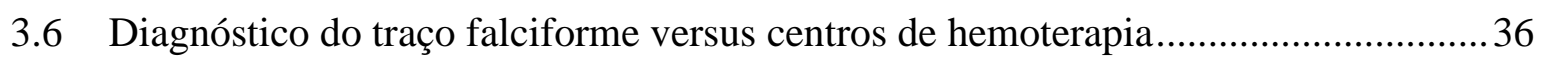

3.7 A cromatografia e a microfluídica como alternativas no diagnóstico.......................40

3.8 Terras Raras como marcadores para diagnósticos ............................................. 44

3.9 Espectroscopia de absorção no infravermelho por transformada de Fourier (FTIR) e

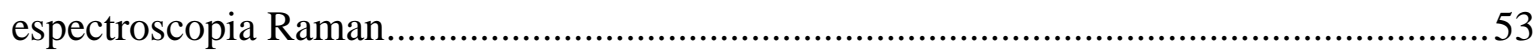

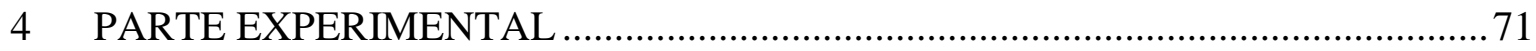

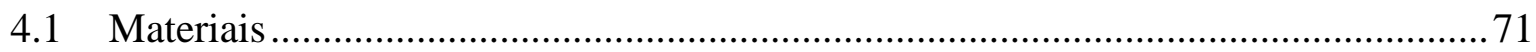

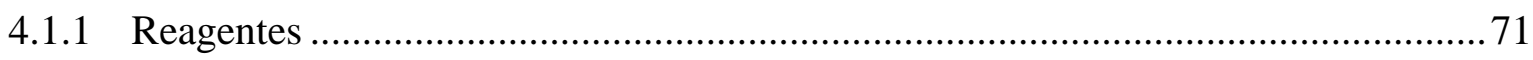

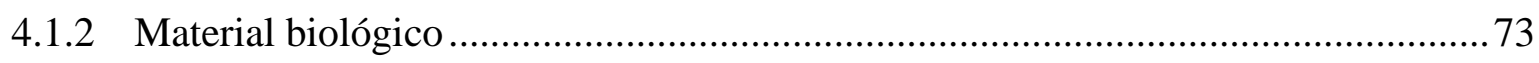

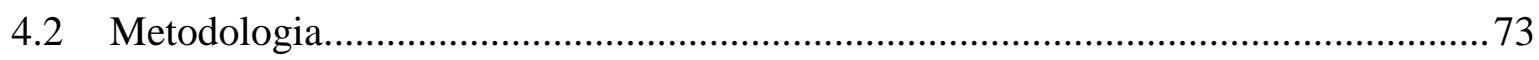

4.2.1 Preparação e estudo dos tampões para análises biológicas ....................................73

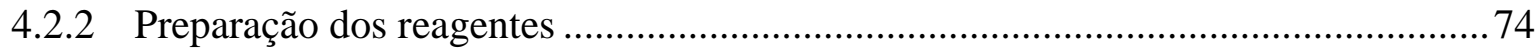

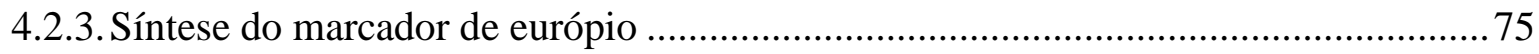

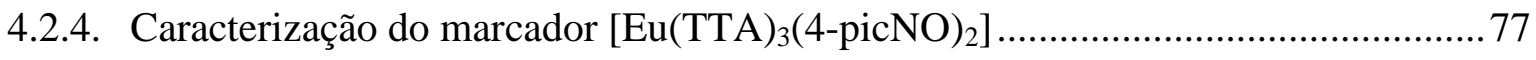

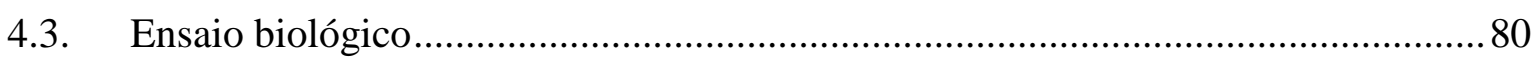

4.3.1. Conjugação do complexo de európio para atuar como marcador .............................. 81

4.4. Diferenciação das amostragens biológicas por espectroscopia Raman e Espectroscopia de Infravermelho por Transformada de Fourier (FTIR) .......................... 82

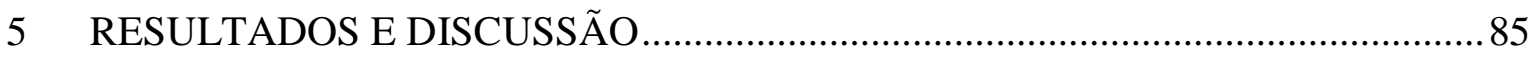


5.1. Síntese e caracterização do marcador luminescente [Eu(TTA $\left.)_{3}(2 \text { picNO })_{2}\right]$ 85

5.2. Ensaios qualitativos da metodologia para detecção de anemia falciforme utilizando tecnologia de testes rápidos de exames (point of care). 96

5.2.1. Estudo da importância da concentração da solução tampão fosfato. .96

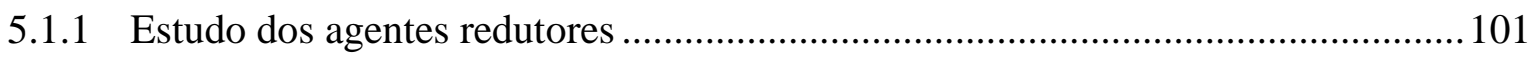

5.2 Marcação das células vermelhas do sangue com complexos de terras raras. 105

5.3 Diferenciação das amostragens biológicas por espectroscopia Raman e espectroscopia de infravermelho por transformada de Fourier (FTIR) ...........................119

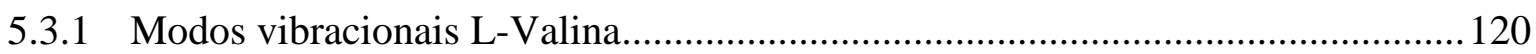

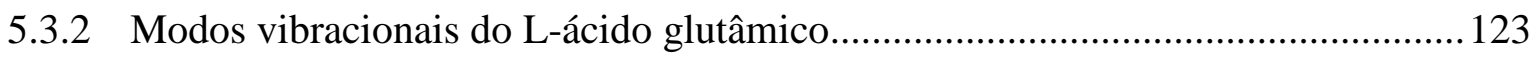

5.4 Análise multivariada por espectroscopia Raman e espectroscopia de infravermelho

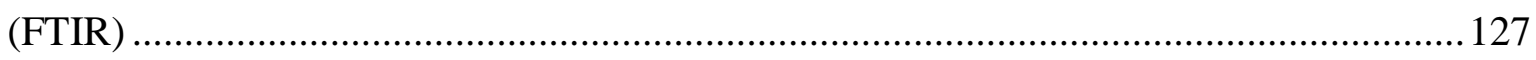

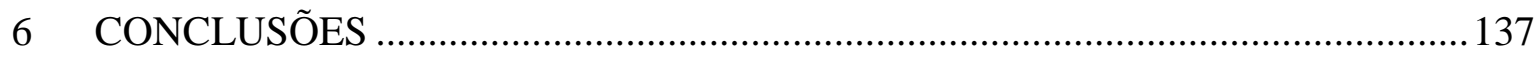

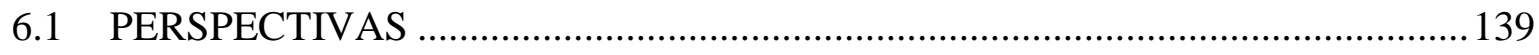

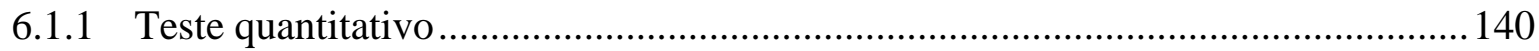

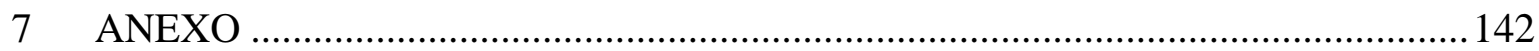




\section{LISTA DE FIGURAS}

FIGURA 1.1. (A) substituição do aminoácido ácido glutâmico (Glu) pelo aminoácido valina (Val); (B) hemácia ou eritrócito, forma arredondada e em foice.

FIGURA 3.1. Representação da hemácia e hemoglobina (conteúdo interno). Figura adaptada de: http://gassama.myweb.uga.edu/ (acessada em 29/11/2013).

FIGURA 3.2. Hemácia normal (com hemoglobina A) e hemácia em forma de foice (com hemoglobina $S)$, respectivamente.

FIGURA 3.3. Papel filtro após experimento para identificação de diferentes tipos de tinta para canetas hidrográficas. Figura adaptada de: http://www.engquimicasantossp.com.br/cromatografia-em-papel.html. (acessada em 20/07/2014)

FIGURA 3.4. (A): representação de um chip microfluídico. O sangue flui da esquerda para a direita, os glóbulos vermelhos e a série branca escoam até um dispositivo de detecção de biomarcadores enquanto o plasma é extraído. (B): foto do chip $(2,5 \mathrm{~cm} \times 5 \mathrm{~cm})$. Créditos: Ivan Dimov/Uc Berkeley. Figura adaptada de: http://lqes.iqm.unicamp.br/canal_cientifico.html. (acessada em 20/07/2014).

FIGURA 3.5. Representação esquemática (qualitativa) do mecanismo de transferência de energia entre um ligante orgânico e o íon $\mathrm{Eu}^{3+}(\mathrm{CI}=$ Conversão Interna/ CIS $=$ Cruzamento Intersistema/ $\mathrm{TE}=$ Transferência de Energia $)^{[105]}$. .48

FIGURA 3.6. Caminho dos elétrons (Raman) ${ }^{[135]}$. .56

FIGURA 3.7. Esquema do mecanismo de espalhamento elástico (Rayleigh) e inelástico (Stokes e anti-Stokes). $v_{0}, v_{\mathrm{S}}$ e $v_{\mathrm{v}}$ são as frequências, proporcionais às energias, da radiação excitante, da radiação espalhada e da transição vibracional, respectivamente ${ }^{[135]}$..............57

FIGURA 4.1. Rota de síntese dos complexos hidratados $\left[\mathrm{Eu}(\mathrm{TTA})_{3}\left(\mathrm{H}_{2} \mathrm{O}\right)_{2}\right] \ldots \ldots \ldots \ldots \ldots \ldots . . . . . . . .76$

FIGURA 4.2. Rota de síntese dos complexos $\left[\mathrm{Eu}(\mathrm{TTA})_{3}(4-\mathrm{picNO})_{2}\right] \ldots \ldots \ldots \ldots \ldots \ldots \ldots \ldots \ldots . . . . . . . . . . . . . . . . .77$ FIGURA 4.3. A: Ilustração esquemática do princípio básico do ensaio biológico em papel de cromatografia. Foi depositado $20 \mu \mathrm{l}$ da mistura final sobre o substrato de papel para análise da formação dos halos. B: Pode-se observar, da esquerda para a direita, halo claro: indicativo da presença apenas da $\mathrm{Hb} \mathrm{AA}$; halo com anel escuro no centro: indicativo da presença de $\mathrm{Hb} \mathrm{AS}$; halo escuro e uniforme: indicativo da presença de $\mathrm{Hb} \mathrm{SS}$.

FIGURA 5.1. Complexo $\left[\mathrm{Eu}(\mathrm{TTA})_{3}(4-\mathrm{picNO})_{2}\right]$ : (A) ausência de radiação solar e (B) presença de radiação ultravioleta $(366 \mathrm{~nm})$. 
FIGURA 5.2. Efeito mesoiônico do grupo fenila nos complexos com $\beta$-dicetonatos. 87

FIGURA 5.3. Espectro de Infravermelho do complexo [Eu(TTA $\left.)_{3}(4-\text { picNO })_{2}\right]$................ 89

FIGURA 5.4. Difratograma de raios X do complexo $\left[\mathrm{Eu}(\mathrm{TTA})_{3}(4-\mathrm{picNO})_{2}\right] \ldots \ldots \ldots \ldots \ldots \ldots . . . . . . . . . .90$

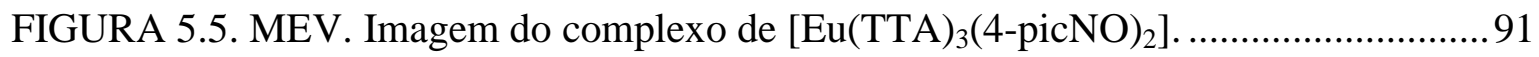

FIGURA 5.6. Espectro de excitação do complexo marcador [Eu(TTA $)_{3}(4-p i c N O)_{2}$ ] em estado sólido, monitorando a emissão em aproximadamente 613nm. Em preto: temperatura ambiente e em vermelho: nitrogênio líquido.

FIGURA 5.7. Espectro de emissão do complexo marcador [Eu(TTA $)_{3}(4 \text {-picNO) })_{2}$ ] estado sólido, monitorando a emissão em $\sim 613 \mathrm{~nm}$.

FIGURA 5.8. Imagem fotográfica dos spots mostrando o desenvolvimento dos halos obtidos utilizando-se as várias concentrações de tampão fosfato para $\mathrm{Hb}$ AS. 97

FIGURA 5.9. Imagem fotográfica, em quadruplicata, dos resultados obtidos utilizando saponina e hidrossulfito de sódio (1:2), 2,3 $\mathrm{mol} \mathrm{L}^{-1}$. Resultados iguais para todas as concentrações dos tampões. Nos controles $\mathrm{Hb}$ AA e alvo $\mathrm{Hb}$ AS os dois últimos halos apresentaram-se mais escuros somente devido à umidade no momento da fotografia. ......99 FIGURA 5.10. Imagem fotográfica, em triplicata, dos resultados obtidos utilizando detergente comercial Limpol® e hidrossulfito de sódio (1:2), 2,3 $\mathrm{mol} \mathrm{L}^{-1}$. Os controles $\mathrm{Hb}$ AA e alvo $\mathrm{Hb}$ AS apresentaram resultados iguais para todas as concentrações dos tampões.

FIGURA 5.11. Imagem fotográfica, em triplicata, dos resultados obtidos utilizando detergente comercial Limpol® (A) e Tween 20 (B), 2,3 mol L ${ }^{-1}$. Os controles Hb AA e alvo $\mathrm{Hb}$ AS apresentaram resultados iguais para todas as concentrações dos tampões citadas anteriormente. Os últimos halos apresentaram-se mais escuros somente devido à umidade no momento do registro da fotografia. 100

FIGURA 5.12. Imagem fotográfica dos resultados obtidos através da substituição do hidrossulfito de sódio (A) por tiossulfato de sódio (B), tanto com detergente comercial Limpol® quanto saponina, 2,3 mol $\mathrm{L}^{-1}$. Os controles $\mathrm{Hb}$ AA e alvo $\mathrm{Hb}$ AS apresentaram resultados iguais para todas as concentrações dos tampões.

FIGURA 5.13. Imagem fotográfica, em triplicata, dos resultados obtidos por meio da substituição do hidrossulfito de sódio por ácido cítrico anidro e peróxido de hidrogênio, tanto com detergente comercial Limpol ${ }^{\circledR}$ ou saponina, 2,3 mol L ${ }^{-1}$. Os controles $\mathrm{Hb}$ AA e alvo $\mathrm{Hb}$ AS apresentaram resultados iguais para todas as concentrações dos tampões. Os últimos halos apresentaram-se mais escuros somente devido à umidade no momento da fotografia. 
FIGURA 5.14. Comparação dos resultados do kit comercial (A) com o método desenvolvido neste trabalho (B), 2,3 mol L $\mathrm{L}^{-1}$. Controle $\mathrm{Hb}$ AA e alvos $\mathrm{Hb}$ AS e $\mathrm{Hb}$ SS. Resultados iguais para todas as concentrações de tampão citadas anteriormente. 104 FIGURA 5.15. Esquema da marcação da célula da hemácia por um marcador de európio.

FIGURA 5.16. Espectro de excitação do marcador [Eu(TTA) $)_{3}(4-\text { picNO })_{2}$ ] no estado sólido e em solução tampão a temperatura ambiente.

FIGURA 5.17. Espectro de emissão do marcador [Eu(TTA) $)_{3}(4-\text { picNO })_{2}$ ] no estado sólido e em solução aquosa à temperatura ambiente. 108 FIGURA 5.18. Espectro de excitação do marcador [Eu(TTA $)_{3}(4-\text { picNO })_{2}$ ] e do marcador conjugado com a Hb AS em solução aquosa à temperatura ambiente. 110

FIGURA 5.19. Espectro de emissão do marcador [Eu(TTA $)_{3}(4-\text { picNO })_{2}$ ] e do marcador conjugado com a $\mathrm{Hb}$ AS em solução aquosa à temperatura ambiente. 111

FIGURA 5.20. Espectro de excitação do marcador [Eu(TTA $)_{3}(4-p i c N O)_{2}$ ] e do marcador conjugado com as hemoglobinas $\mathrm{HbAS}$, HbSS e HbAA em solução aquosa à temperatura ambiente. 112

FIGURA 5.21. Espectro de emissão do marcador [Eu(TTA $)_{3}(4-\text { picNO })_{2}$ ] e do marcador conjugado com as hemoglobinas $\mathrm{Hb} \mathrm{AS}, \mathrm{Hb}$ SS e $\mathrm{Hb} \mathrm{AA}$ em solução aquosa à temperatura ambiente. 112

FIGURA 5.22. Microscopia Eletrônica de Varredura. A: hemácias do padrão Hb AS na solução tampão; B: hemácias do padrão Hb AS na solução tampão em um campo maior mostrando além das hemácias o tampão e as partículas do marcador; C: o marcador e D: o tampão fosfato.

FIGURA 5.23. Exemplo da utilização do marcador no exame tipo point of care. 116

FIGURA 5.24. Curvas das cores padrões CIE para $x(\lambda), y(\lambda)$ e $z(\lambda)$. 117 FIGURA 5.25. Diagramas de cromaticidade CIE ilustrando as coordenadas das cores emitidas pelo marcador e pelos sistemas marcador- Hemoglobina $(298 \mathrm{~K})^{[44]}$. 118 FIGURA 5.26. Espectro teórico das características vibracionais gerais dos aminoácidos.

FIGURA 5.27. Estrutura L-valina. Ácido 2-aminovalérico ou Ácido 2-amino-3-metilbutanóico $\left(\mathrm{C}_{5} \mathrm{H}_{11} \mathrm{O}_{2} \mathrm{~N}\right)$ - (Butantã).

FIGURA 5.28. Espectro de infravermelho e Raman da valina evidenciando as bandas de amida I e II entre aproximadamente 1500 e $1700 \mathrm{~cm}^{-1}$.

FIGURA 5.29. Estrutura L-ácido glutâmico $\left(\mathrm{C}_{5} \mathrm{H}_{9} \mathrm{NO}_{4}\right)$ - (Ajinomoto/Butantã). 123 
FIGURA 5.30. Espectro de infravermelho e Raman do ácido glutâmico evidenciando as bandas de amida I e II entre aproximadamente 1500 e $1700 \mathrm{~cm}^{-1}$. 125

FIGURA 5.31. Espectro de infravermelho dos padrões de sangue total evidenciando as bandas de amida I e II entre aproximadamente 1500 e $1700 \mathrm{~cm}^{-1}$. Legenda: Hb AA kit e $\mathrm{Hb}$ AS kit - ensaios biológicos com a solução do kit comercial. Hb AA*, $\mathrm{Hb}^{*} \mathrm{AS}^{*}$ e $\mathrm{Hb} \mathrm{AS}$ $\mathrm{d} *$ - ensaios biológicos com as soluções desenvolvidas no laboratório e $\mathrm{d}^{*}$ - solução desenvolvida com detergente comercial. $\mathrm{Hb}$ AA (sangue sem falciforme) e $\mathrm{Hb}$ AS (sangue com traço falciforme) 126

FIGURA 5.32. Espectro Raman dos padrões de sangue total. Legenda: Hb AA kit e Hb AS kit - ensaios biológicos com a solução do kit comercial. $\mathrm{Hb}^{\mathrm{AA}} \mathrm{A}^{*}, \mathrm{Hb} \mathrm{AS}$ * e $\mathrm{Hb} \mathrm{AS}$ d *_ ensaios biológicos com as soluções desenvolvidas no laboratório e $\mathrm{d}^{*}$ - solução desenvolvida com detergente comercial. $\mathrm{Hb}$ AA (sangue sem falciforme) e $\mathrm{Hb}$ AS (sangue com traço falciforme)

FIGURA 5.33. Análise multivariada por espectroscopia de infravermelho (FTIR). Legenda: $\mathrm{Hb}$ AA kit e $\mathrm{Hb}$ AS kit - ensaios biológicos com a solução do kit comercial. Hb AA (meu), Hb AS (meu) - ensaios biológicos com as soluções desenvolvidas no laboratório. $\mathrm{Hb} \mathrm{AA}$ (sangue sem falciforme) e $\mathrm{Hb}$ AS (sangue com traço falciforme). Desconsiderar ACkit e ACmeu, pois foram testes fora do conteúdo deste trabalho. 129

FIGURA 5.34. Análise multivariada por espectroscopia Raman. Legenda: Hb AA kit e Hb AS kit - ensaios biológicos com a solução do kit comercial. Hb AA (meu), Hb AS (meu) e $\mathrm{Hb}$ ASD (meu) - ensaios biológicos com as soluções desenvolvidas no laboratório. $\mathrm{Hb} \mathrm{AA}$ (sangue sem falciforme) e $\mathrm{Hb}$ AS (sangue com traço falciforme). Desconsiderar ACkit e ACmeu, pois foram testes fora do conteúdo deste trabalho. 


\section{LISTA DE TABELAS}

TABELA 4.1. Relação das substâncias usadas e suas procedências. ..................................71

TABELA 4.2. Detergentes e agentes redutores testados e suas respectivas diluições........74

TABELA 5.1. Parâmetros de intensidade $\left(\Omega_{\lambda}\right)$, R02 e R04 determinado em 298 K para o

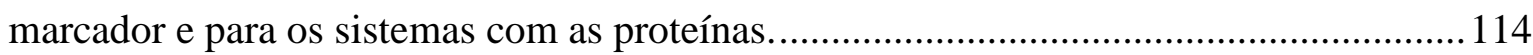

TABELA 5.2. Valores aproximados das coordenadas de cores dos materiais funcionalizados. 


\section{LISTA DE ABREVIATURAS}

ANVISA - Agência Nacional de Vigilância Sanitária

AF - Anemia Falciforme

FTIR - Espectroscopia de absorção no infravermelho por Transformada de Fourier

RAMAN - Espectroscopia vibracional Raman

Hb - Hemoglobina

Hb A - Hemoglobina normal

Hb F - Hemoglobina fetal

Hb S - Hemoglobina "alterada"

WHO - Organização Mundial de Saúde

SCA - Sickle cell disease

4-picNO - 4-picolina-N-óxido

MEV - Microscopia eletrônica de varredura 
1

\section{Introdução}




\section{INTRODUÇÃO}

Segundo estimativas da Organização Mundial de Saúde (OMS), a cada ano, nascem no Brasil cerca de 3.500 crianças com anemia falciforme (AF). Vinte por cento delas não atingem cinco anos de idade por complicações diretamente relacionadas à doença, sendo assim, a OMS reconheceu a urgente necessidade do desenvolvimento de um diagnóstico de baixo custo para anemia falciforme ${ }^{[1]}$.

No Brasil apenas em 2005 foi criada a Portaria 1391 que instituiu para o SUS as diretrizes para a Política Nacional de Atenção Integral às pessoas portadoras de Doença Falciforme, provendo assistência aos indivíduos com diagnóstico tardio ${ }^{[2]}$; e um decreto 45.555, de 2008, que instituiu uma Política Estadual de Atenção Integral às Pessoas com Doença Falciforme com o objetivo de identificar os portadores da doença e de oferecerlhes assistência médica, psicossocial, medicamentos e imunobiológicos necessários.

A anemia falciforme foi relatada pela primeira vez em $1910^{[3]}$. Provavelmente surgiu em países do centro oeste africano, da Índia e do leste da Ásia há cerca de 50 a 100 mil anos atrás e ocorria frequente em indivíduos negros. Atualmente devido à miscigenação dos povos a AF não é mais uma doença exclusiva dos negros ${ }^{[4]}$.

No Brasil acredita-se que a AF seja a doença hereditária que mais prevalece ${ }^{[5]}$, portanto considerada um problema de saúde pública ${ }^{[1]}$. Alguns estudos apontaram que existe uma prevalência de aproximadamente 4 a $5 \%$ de recém-nascidos portadores da doença $^{[6]}$. As regiões que apresentam maior incidência são as regiões norte e nordeste ${ }^{[7]}$.

Segundo dados da APAE-Salvador, em agosto de 2000 a incidência desta patologia no estado baiano (alta população de afrodescendentes) foi de 1.655 nascidos vivos com anemia falciforme ${ }^{[7]}$.

Nos EUA a anemia falciforme é considerada também um significativo problema de saúde pública, cerca de 5.000 gestações por ano são de alto risco e 1 em 400 
afro-americanos recebe tratamento para anemia falciforme no sistema de saúde americano $^{[8]}$.

Já na África nascem anualmente 120.000 bebês com anemia falciforme comprovada $^{[9]}$.

A AF é uma doença do grupo das hemoglobinopatias extremamente comum e é causada por uma alteração molecular no cromossoma $11^{[10]}$, que é a substituição do aminoácido ácido glutâmico (Glu) pelo aminoácido valina (Val) na posição 6 da cadeia de $\beta$-globina, FIG 1.1 (a). Essa alteração faz com que a hemoglobina (Hb), presente nas hemácias, apresente uma deformação estrutural comprometendo toda a distribuição de oxigênio pelo organismo.

Quando dois genes são afetados com essa mutação (homozigose, Hb SS), o indivíduo possui a anemia falciforme. Contudo, quando apenas um gene é afetado (heterozigose, $\mathrm{Hb} \mathrm{AS}$ ) considera-se o indivíduo portador do traço falciforme, mas que clinicamente evolui como uma pessoa sem a doença ${ }^{[5]}$.

$\mathrm{O}$ agravamento da $\mathrm{AF}$ se inicia pelo decréscimo do nível de oxigênio no sangue que ocasiona a polimerização morfológica das hemácias (glóbulos vermelhos), pois a $\mathrm{Hb} \mathrm{S}$ perde sua complexa estrutura quaternária e adquire uma estrutura primária e as hemácias assumem uma forma anômala de foice, FIG 1.1 (b). Os glóbulos vermelhos deformados e alongados, não conseguem passar através de pequenos vasos sanguíneos, bloqueando-os e impedindo a circulação do sangue nas áreas periféricas causando danos como, por exemplo, a formação de trombos e necrose dos tecidos circunvizinhos, provocando dor e comprometendo o sistema circulatório. 

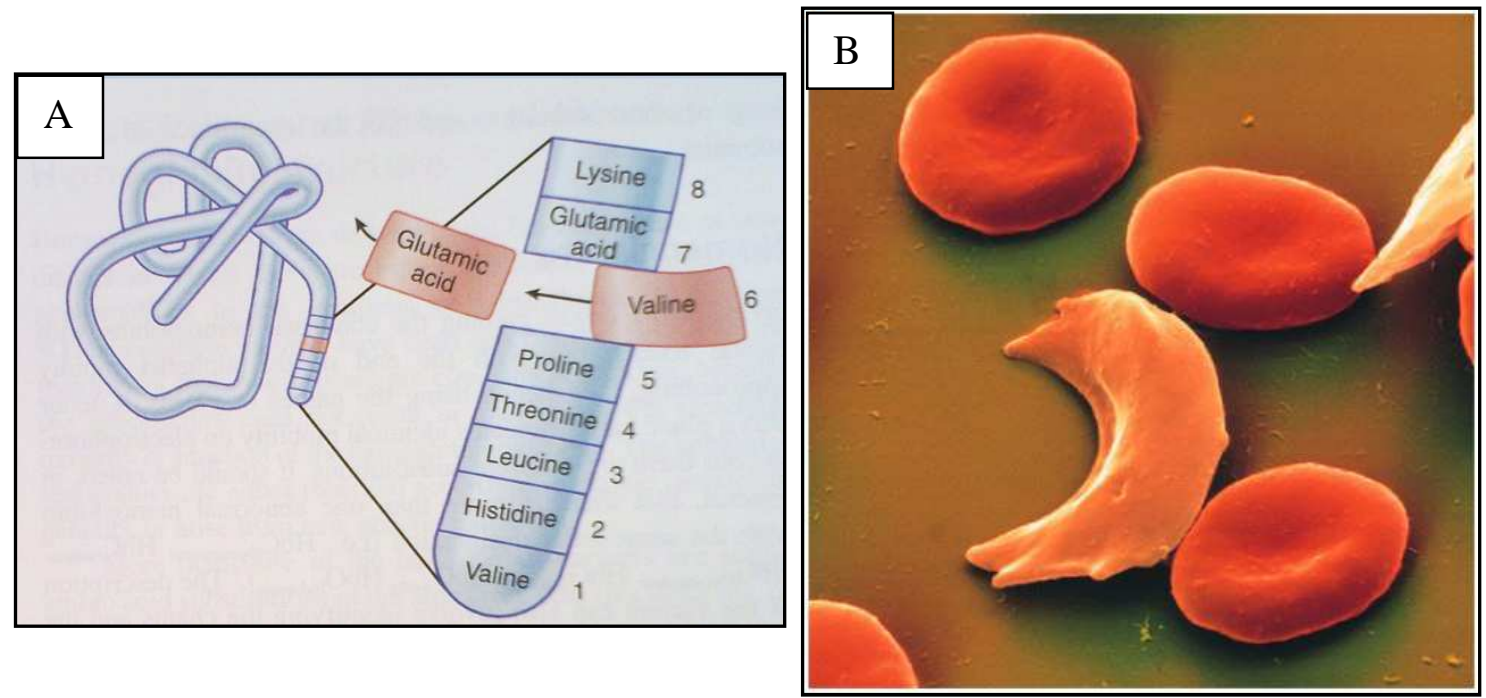

FIGURA 1.1. (A) substituição do aminoácido ácido glutâmico (Glu) pelo aminoácido valina (Val); (B) hemácia ou eritrócito, forma arredondada e em foice.

De modo geral, além de anemia crônica, as diferentes formas de doenças falciformes caracterizam-se por numerosas complicações que podem afetar quase todos os órgãos e sistemas do corpo humano, com expressiva morbidade, redução da capacidade de trabalho e da expectativa de vida ${ }^{[11]}$.

Pacientes adultos quando se apresentam ao pronto-socorro com queixas de dores são medicados com drogas não adequadas, por falta de diagnóstico correto, e são frequentemente estigmatizados ${ }^{[12]}$.

Atualmente uma das consequências mais preocupantes da $\mathrm{AF}$ é a deficiência auditiva em crianças, pois os prejuízos causados por essa deficiência muitas vezes são irreversíveis, afetando não apenas a linguagem oral, mas também o desenvolvimento global dela e o de seu rendimento escolar ${ }^{[13]}$.

Os métodos de diagnóstico da anemia falciforme vão desde eletroforese de hemoglobina $(E H G)^{[14]}$, focalização isoelétrica $(\mathrm{IEF})^{[15,16]}$ e até cromatografia líquida de alta eficiência (HPLC) ${ }^{[17]}$. Para isso é necessário que existam laboratórios clínicos equipados com instrumentos especializados e técnicos altamente treinados, sendo que esses recursos não estão disponíveis em lugares com baixo índice de desenvolvimento, pobreza 
acentuada ou localidades de difícil acesso ${ }^{[18]}$. Além disso, a necessidade de transportar as amostras de sangue de um ponto isolado do Brasil até um laboratório centralizado e equipado com tais tecnologias, torna o diagnóstico definitivo da anemia falciforme quase impossível $^{[14]}$.

Nas décadas de 70 e 80 a polimerização da $\mathrm{Hb} \mathrm{S}$ era observada apenas através de um ensaio experimental com sangue e solução tampão acrescida com detergentes moleculares e redutores químicos. Nestes ensaios a saponina era utilizada para lisar/quebrar as hemácias do sangue em meio a um tampão fosfato, fazendo com que todos os tipos de hemoglobinas fossem dispersas no meio líquido e logo em seguida apenas a hemoglobina S, cuja estrutura é anormal, fosse desoxigenada na presença de agentes químicos redutores. Devido a este processo bioquímico qualitativo, a hemoglobina $\mathrm{S}$ poderia ser vista após horas, a olho nu, polimerizada em suspensão ${ }^{[19,20]}$.

Observou-se, na literatura, que a insolubilidade da $\mathrm{Hb} \mathrm{S}$, em tampão fosfato concentrado 2,3 mol L ${ }^{-1}$, referenciada por um grupo de pesquisadores de Tulane University nos Estados Unidos, pode se tornar uma das ferramentas auxiliares para detecção não só qualitativa como quantitativa da hemoglobina S. Este grupo utiliza um kit comercial para diagnóstico da anemia falciforme, porém é um material que se torna caro quando importado, pois além de conter tampão fosfato de potássio altamente concentrado contém também um agente dispersante e/ou detergente (saponina), um agente químico redutor (hidrossulfito de sódio) e um conservante inibidor do crescimento de microorganismos (2cloroacetamida). $\mathrm{O}$ resultado deste teste qualitativo pode ser visualizado na hora em papel cromatográfico e pode ser quantificado através de programas computacionais específicos $^{[21]}$.

Neste trabalho foi desenvolvido um método de triagem diagnóstica barata e de fácil execução para a anemia falciforme que será uma alternativa preventiva para as populações que moram em comunidades distantes e carentes, principalmente nos sertões do Brasil onde as condições financeiras do sistema de saúde são quase inexistentes.

$\mathrm{Na}$ metodologia desenvolvida, pelo nosso grupo, uma gota de sangue misturado à solução do ensaio biológico, foi depositada em papel cromatográfico. $\mathrm{A} \mathrm{Hb} \mathrm{S}$ polimerizada, devido à desoxigenação, permaneceu retida nas fibras do papel enquanto que 
a hemoglobina "normal" (Hb AA) permaneceu livre para fluir pelo papel formando um halo colorido. A disposição e a cor do halo formado através dessa mistura foi o indicativo do conteúdo presente em cada amostra, permitindo diferenciar os tipos de hemoglobinas. Neste fenômeno físico-químico, semelhante à cromatografia em papel, acontece uma separação dos componentes de uma mistura, como na cromatografia líquido-líquido em papel. Os componentes mais solúveis têm uma movimentação mais rápida ao longo do papel, enquanto que os menos solúveis tem uma movimentação mais lenta e são seletivamente retidos ${ }^{[22]}$.

Portanto, este método é o objetivo deste trabalho de tese que juntamente com análises por espectroscopia vibracional de infravermelho e Raman vêm fundamentar este trabalho de doutoramento. Com esta metodologia desenvolvida será possível que os profissionais da saúde dirijam-se até as casas mais carentes do país para realizar o diagnóstico da anemia falciforme rapidamente, orientar as pessoas em relação às consequências dessa doença e os futuros cuidados.

Este caminho de diagnóstico é uma oportunidade para a população pobre, pois uma criança ao nascer não apresenta nenhuma característica visível de ser portadora da AF. Uma vez com o diagnóstico em mãos os pais de crianças com anemia falciforme poderão ser orientados em tempo hábil sobre as consequências clínicas e sequelas dessa doença garantindo a identificação do recém-nascido portador da AF e do seu direito de receber assistência médica, psicossocial, medicamentos e imunobiológicos necessários, como diz a Lei, evitando futuros sofrimentos.

De fato, é assegurado por lei e de fundamental importância diagnosticar corretamente a população mais carente, enquanto crianças, e informar a família dos falcêmicos sobre seus direitos, pois na maioria das vezes essas pessoas são ignoradas. 


\section{REFERÊNCIAS BIBLIOGRÁFICAS}

[1] DIAllO, D., Tchernia, G. Sickle cell disease in Africa. Curr. Opin. Hematol., v. 9: p. 111-116, 2002.

[2] CRUSIUS, Y.R. Política Estadual de Atenção Integral às Pessoas com Doença Falciforme e outras Hemoglobinopatias. Disponível em: <http://www.saude.rs.gov.br/upload/1337785202_PoliticaFalciforme.pdf>. Acesso em: 24 jun. 2014.

[3] HERRICK, J.B. Peculiar elongated and sickle-shaped red blood corpuscles in a case of severe anemia. Arch. Intern. Med., v. 6, n. 5, p. 517-521, 1910.

[4] WHO Working Group. Hereditary anemias: genetics basis, clinical features, diagnosis and treatment, WHO, v. 60, p. 643-660, 1982.

[5] BANDEIRA, F.M.G.C.; LEAL, M.C.; SOUZA, R.R.; FURTADO, V.C.; GOMES, Y.M.; MARQUES, N.M. Características de recém-nascidos portadores de hemoglobina S detectados através de triagem em sangue de cordão umbilical. J. Pediatr., v. 75, n. 3, p. 167-171, 1999.

[6] Programa de Atenção às Pessoas com Doença Falciforme. Manual do Agente de Saúde. Grupo de Trabalho de saúde da População Negra-GTSPN/SMS/SEMUR. Salvador; 2005 .

[7] CANÇADO, R.D., JESUS, J.A. A doença falciforme no Brasil. Rev Bras Hematol Hemoter., v. 29, n. 3, p. 204-206, 2007.

[8] BURCH-SIMS, G.P.; MATLOCK, V.R. Hearing Loss and auditory function in sickle cell disease. J. Commun. Disord., v. 38, n. 4, p. 321-329, 2005.

[9] EMBURY, S.H. Anemia falciforme e hemoglobinopatias associadas. 20 ed. Rio de Janeiro: Guanabara Koogan, 1997.

[10] SAIZ, A.; RODRIGUEZ, J.A. Respuesta inmune humoral anti-streptococcus pneumoniae en pacientes con anemia de celulas falciformes: Descripcion de un caso. Rev. Asoc. Colomb. Alerg. Inmunol., v. 8, n. 3, p. 54-54, 1999.

[11] SILVA, W.S.; LASTRA, A.; OLIVEIRA, S.F.; KLAUTAU-GUIMARÃES, N.; GRISOLIA, C.K. Avaliação da cobertura do programa de triagem neonatal de 
hemoglobinopatias em populações do Recôncavo Baiano, Brasil. Cad Saúde Pública, v. 22, n. 12, p. 2561-2566, 2006.

[12] WRIGHT, K.; ADEOSUM, O. Barriers to effective pain management in sickle cell disease. Br. J. Nurs., v. 18, p. 158-161, 2009.

[13] KRAL, M.C.; BROWN, R.T.; HYND, G.W. Neuropsychological aspects of pediatric sickle cell disease. Neuropsychol Rev., v. 11, n. 4, p. 179-196, 2001.

[14] CLARKE, G.M.; HIGGINS, T.N. Laboratory investigation of hemoglobinopathies and thalassemias: review and update. Clin. Chem., v. 46, p. 1284-1290, 2000.

[15] RODRIGUEZ-DIAZ, R.; WEHR, T.; ZHU, M. Capillary isoelectric focusing. Electrophoresis, v. 18, p. 2134-2144, 1997.

[16] JENKINS, M.A.; RATNAIKE, S. Capillary isoelectric focusing of haemoglobin variants in the clinical laboratory. Clin. Chim. Acta, v. 289, p. 121-132, 1999.

[17] HEAD, C.E.; CONROY, M.; JARVIS, M.; PHELAN, L.; BAIN, B.J. Some observations on the measurent of haemoglobin $A_{2}$ and $S$ percentages by high performance liquid chromatography in the presence and absence of thalassaemia. J. Clin. Pathol., v. 57, p. 276-280, 2004.

[18] WEATHERALL, D.J.; CLEGG, J.B. Inherited haemoglobin disorders: an increasing global health problem. Bull. World Health Organ., v. 79, p. 704-712, 2001.

[19] MATUSIK, J.E.; POWELL, J.B.; GREGORY, D.M. Rapid solubility test for detection of hemoglobin. Clin. Chem., v. 17, p. 1081-1082, 1971.

[20] SCHMIDT, R.M.; WILSON, S.M. Standardization in detection of abnormal hemoglobins. J. Am. Med. Assoc., v. 225, p. 1225-1230, 1973. 
[21] YANG, X.; KANTER, J.; PIETY, N.Z.; BENTON, M.S.; VIGNES, S.M.; SHEVKOPLYAS, S.S. A simple, rapid, low-cost diagnostic test for sickle cell. Lab. Chip., v. 13, p. 1464-1467, 2013.

[22] COLLINS, C. H.; BRAGA, G. L. Introdução a Métodos cromatográficos. 1 ed. Campinas: Editora da Unicamp, 1987. 
2

Objetivo 


\section{OBJETIVO}

Este trabalho teve como objetivo o desenvolvimento de uma metodologia alternativa, de triagem diagnóstica da anemia falciforme, eficiente e de baixo custo utilizando tecnologia point-of-care para exames de testes rápidos.

\subsection{Objetivos específicos}

- Desenvolver uma alternativa para detecção rápida e eficiente de hemoglobinas $\mathrm{Hb} \mathrm{AA}, \mathrm{Hb}$ AS e Hb SS;

- Desenvolver um marcador luminescente à base de terras raras para auxiliar na detecção das hemoglobinas na metodologia point-of-care;

- Desenvolver uma metodologia alternativa para identificação de $\mathrm{Hb} \mathrm{AA}, \mathrm{Hb}$ AS e Hb SS via espectroscopia de absorção na região do infravermelho e espectroscopia Raman para servir de método comparativo;

- Criar modelo matemático de diferenciação da Hb AA, Hb AS e Hb SS por espectroscopia vibracional de infravermelho e espectroscopia Raman. 
3

Revisão da Literatura 


\section{REVISÃO DA LITERATURA}

\subsection{Hemoglobinas}

Hemácias, eritrócitos ou glóbulos vermelhos, FIG. 3.1, são unidades morfológicas da série vermelha do sangue e constituídas por hemoglobinas (Hb), que são responsáveis pela cor vermelha do sangue ${ }^{[1]}$.

A hemoglobina, FIG. 3.1, é uma proteína composta por dois pares de cadeias polipeptídicas de estrutura terciária e quatro grupamentos heme que contém ferro, cada íon de ferro é capaz de se ligar frouxamente a dois átomos de oxigênio, um para cada molécula de hemoglobina e a sua função é transportar oxigênio e gás carbônico aos tecidos ${ }^{[2]}$.

No sangue dos adultos normais existem duas cadeias alfa e duas cadeias beta, formando a hemoglobina A1 mais duas cadeias alfa e duas delta formando a hemoglobina A2. Durante o desenvolvimento fetal acontece uma predominância na síntese de cadeias gama no lugar das cadeias beta que, associadas às cadeias alfa, dão origem a hemoglobina fetal ( $\mathrm{Hb} \mathrm{F})$ que protege o bebê até os seis meses de vida das consequências da AF, pois a hemoglobina fetal é normal diferentemente das hemoglobinas dos adultos que é anormal ${ }^{[3]}$.

As alterações das hemoglobinas, nos bebês a partir do sexto mês de vida, aparecem como resultado de mutações dos genes alfa, beta, gama ou delta, responsáveis pelo seu sequenciamento e estrutura. É causada por uma mutação no cromossoma 11, determinando uma substituição do aminoácido ácido glutâmico (Glu) pela valina (Val) na posição 6 da cadeia $\beta$-globina. Como consequência, as cadeias de globina se formam de maneira anormal e são chamadas de hemoglobinas variantes perturbando a função normal desempenhada pelas hemácias ${ }^{[4]}$.

Existe um grande número de hemoglobinas variantes, estas compreendem um grupo de distúrbios hereditários que afetam os genes que codificam as cadeias globínicas alfa e beta da molécula da hemoglobina. Essas desordens hereditárias, chamadas de hemoglobinopatias, afetam aproximadamente $7 \%$ da população mundial. 
Devido à alta prevalência e gravidade de suas manifestações clínicas essas desordens genéticas representam um problema de saúde pública em muitos países. Atualmente, já foram descritas mais de 1.200 mutações nos genes das cadeias globínicas, dentre estas, a anemia falciforme é a patologia hereditária mais encontrada e clinicamente significante ${ }^{[5]}$.

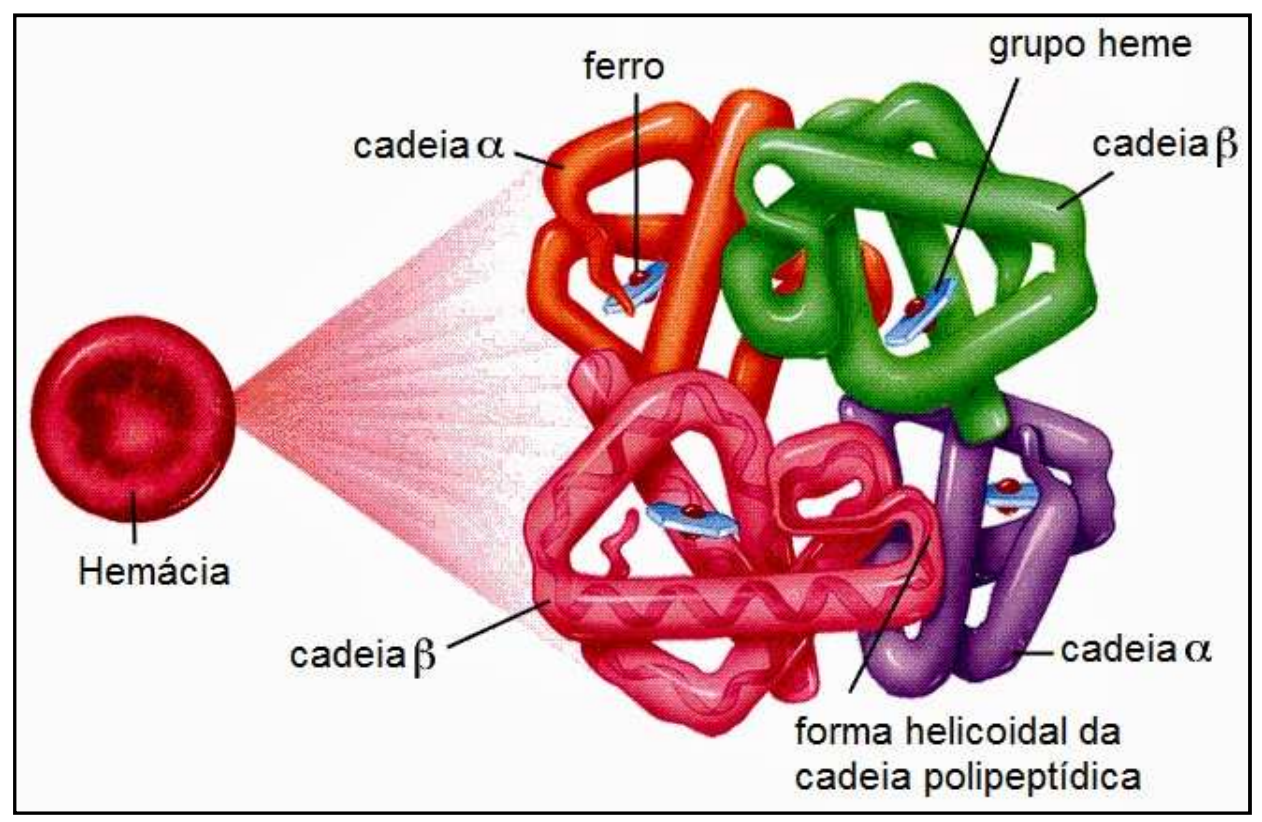

FIGURA 3.1. Representação da hemácia e hemoglobina (conteúdo interno). Figura adaptada de: http://gassama.myweb.uga.edu/ (acessada em 29/11/2013).

\subsection{Anemia Falciforme}

A anemia falciforme (AF) foi relatada pela primeira vez em $1910^{[6]}$. Provavelmente surgiu em países do centro oeste africano, da Índia e do leste da Ásia há cerca de 100 mil anos e ocorre frequentemente em indivíduos negros, mas atualmente não é exclusiva, devido à miscigenação dos povos ${ }^{[7]}$.

A anemia falciforme é a doença hereditária, mais comum, causada por uma mutação pontual na hemoglobina e está associada com morbidade significativa e mortalidade prematura. Cada molécula de hemoglobina normal ( $\mathrm{Hb} \mathrm{A})$ consiste em duas 
cadeias alfa-globínicas e duas cadeias beta-globínicas. A troca de um único nucleotídeo no gene substitui a produção do aminoácido ácido glutâmico pela produção do aminoácido valina, prejudicando a formação da $\mathrm{Hb} \mathrm{A}$ e consequentemente a estrutura final da hemácia, FIG. $3.2^{[8]}$.

Indivíduos que herdam duas cópias de $\mathrm{Hb} \mathrm{S}$ (homozigose, $\mathrm{Hb} \mathrm{SS}$ ) desenvolvem a doença que é a forma mais grave de anemia falciforme e que responde por quase $75 \%$ de todos os casos. Contudo, quando apenas um gene é afetado (heterozigose, $\mathrm{Hb}$ AS) o indivíduo é somente portador do traço falciforme e evolui normalmente como uma pessoa sem a doença.

Acredita-se que a AF seja a doença hereditária mais comum no Brasil e se tornou um problema de saúde pública ${ }^{[9]}$.

No Brasil, em 2005, criou-se a Portaria 1391 que instituiu para o Sistema Único de Saúde (SUS) as diretrizes para a Política Nacional de Atenção Integral às pessoas portadoras de Doença Falciforme provendo assistência aos indivíduos com diagnóstico tardio. Criou-se também o Decreto 45.555, de 2008, que instituiu uma Política Estadual de Atenção Integral às Pessoas com Doença Falciforme com o objetivo de identificar os portadores da doença e de oferecer-lhes tanto assistência médica e psicossocial quanto os medicamentos e imunobiológicos necessários ${ }^{[10]}$.

Segundo o Programa Nacional de Triagem Neonatal (PNTN) a cada ano nascem no Brasil cerca de 3.500 crianças com a doença falciforme, ou seja, 1 criança para cada 1.000 nascidos vivos, e cerca de 200.000 crianças por ano com traço falciforme ${ }^{[11]}$.

Alguns estudos apontaram que existe uma prevalência de aproximadamente 4 a $5 \%$ de recém-nascidos portadores da doença ${ }^{[12]}$. As regiões com maior incidência foram no norte e nordeste ${ }^{[13]}$.

Segundo dados da APAE-Salvador, em agosto de 2000 a incidência desta patologia foi de 1.655 nascidos vivos com anemia falciforme e de uma criança com traço falciforme para cada 17 nascimentos ${ }^{[14]}$. 

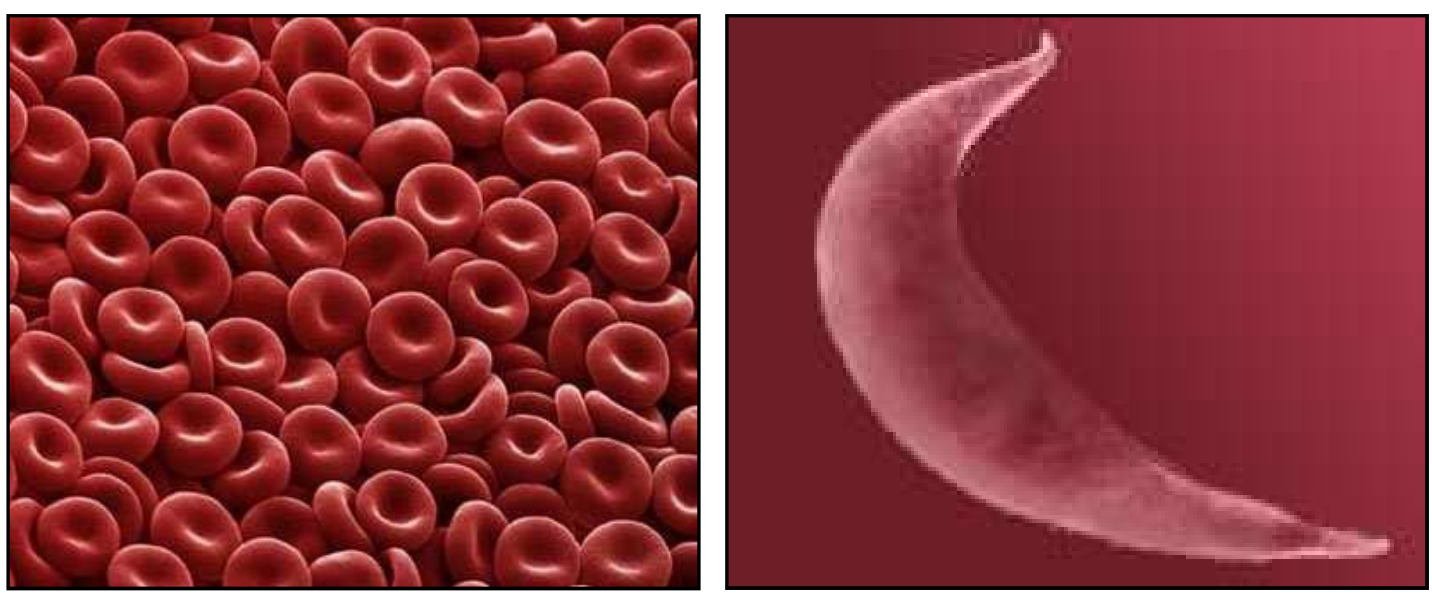

FIGURA 3.2. Hemácia normal (com hemoglobina A) e hemácia em forma de foice (com hemoglobina $S$ ), respectivamente.

Na África cerca de 700 crianças nascem com anemia falciforme todos os dias ( $75 \%$ de todos os nascimentos em todo o mundo) e mais de 50\% delas vão morrer antes de atingir a idade adulta devido à falta de diagnóstico e tratamento ${ }^{[15]}$. Nos Estados Unidos, para efeito de comparação, a maioria das crianças que nascem com anemia falciforme é capaz de sobreviver até a idade adulta, principalmente pelo fato de lá existir um programa eficaz de rastreio e que leva ao tratamento dessa doença e de outras hemoglobinopatias $\operatorname{associadas}^{[16]}$.

As manifestações da anemia falciforme são variáveis, pois seu aspecto de aparecimento depende da quantidade de hemoglobina $S$ presente no sangue e do grau de oxigenação da hemácia. Dentre os principais sintomas relacionados à anemia falciforme alguns merecem destaque, tais como: 


\subsubsection{Consequências da Anemia Falciforme}

\subsubsection{Deficiência auditiva}

Atualmente uma das consequências mais preocupantes da anemia falciforme é a deficiência auditiva em crianças, pois os prejuízos causados por essa deficiência muitas vezes são irreversíveis, afetando não apenas seu desenvolvimento na linguagem oral e global como também o seu próprio rendimento escolar ${ }^{[17]}$.

\subsubsection{Crises álgicas}

Geralmente é a primeira manifestação clínica da anemia falciforme. É decorrente da obstrução do fluxo sanguíneo pelas hemácias falcizadas. As crises dolorosas pelo corpo ocorrem durante quatro a seis dias, podendo persistir por semanas. Hipóxia, infecção, febre, acidose, desidratação e exposição ao frio extremo podem precipitar as crises álgicas.

\subsubsection{Febre e infecções}

Devido à alta associação de infecções em pacientes com anemia falciforme, a febre é um dos sinais mais comuns e devem ser encarados como situações de risco ${ }^{[18]}$.

O risco de septicemia ou até mesmo meningite por Streptococcus pneumoniae ou Haemophilus influenzae chega a ser 600 vezes maior em crianças com anemia falciforme. Tais infecções podem provocar morte em poucas horas. Pneumonias, infecções renais e osteomielites também ocorrem com frequência maior em crianças e adultos com doença falciforme ${ }^{[19]}$.

\subsubsection{Baixa imunidade}

Os processos vaso-oclusivos repetidos no baço levam ao seu não funcionamento, redução da função esplênica e consequente diminuição da capacidade imunológica. A diminuição da capacidade imunológica faz com que haja mais 
susceptibilidade a infecções por Pneumococcus pneumoniae e Haemophilus influenzae ${ }^{[20]}$. Portanto, é imprescindível o inicio de um programa eficaz de imunizações em crianças com anemia falciforme, antes dos cinco anos de idade ${ }^{[18]}$.

\subsubsection{Crise de sequestro esplênico}

É o acúmulo de grande volume de hemácias no baço e a uma diminuição súbita da hemoglobina plasmática, podendo levar a um choque hemorrágico. É a causa mais comum de mortes em crianças com anemia falciforme, ocorrendo geralmente a partir dos seis meses de vida até os dois anos de idade ${ }^{[21]}$.

\subsubsection{Litíase biliar}

Ocorre em 14\% das crianças menores de dez anos, em 30\% dos adolescentes e em 75\% dos adultos portadores da anemia falciforme. Ocorre formação de múltiplos cálculos biliares e em $60 \%$ dos casos esses cálculos são radiopacos podendo ser assintomáticos por muito tempo ou causar sintomas crônicos como empachamento, náuseas, vômitos e dores no abdômen ${ }^{[22]}$. As complicações mais comuns são a colecistite, obstrução do ducto biliar e, mais raramente, pancreatite aguda ${ }^{[20]}$.

\subsubsection{Acidente Vascular Encefálico}

Ocorre em $10 \%$ dos pacientes com anemia falciforme ${ }^{[23]}$ devido à isquemia e infarto que são decorrentes da obstrução de artérias cerebrais. As manifestações neurológicas são geralmente focais e podem incluir hemiparesia (paralisia parcial de um lado do corpo), hemianestesia, deficiência do campo visual, alteração da linguagem e paralisia de nervos cranianos. Sinais mais generalizados como coma e convulsões também podem ocorrer ${ }^{[24]}$. A recidiva do acidente vascular cerebral provoca danos maiores e aumenta a mortalidade ${ }^{[25]}$. 


\subsubsection{8 Úlceras de pernas}

Presentes entre 8 a 10\% dos portadores da anemia falciforme são mais comuns após os dez anos de vida. As úlceras geralmente se localizam no terço inferior das pernas próximas aos maléolos medial e lateral. Podem também aparecer sobre a tíbia ou dorso do pé. Tais feridas estão associadas a crises vaso-oclusivas e a microtraumatismos ${ }^{[26]}$.

\subsubsection{Aborto}

A gravidez promove alto risco para a gestante e o aborto espontâneo ocorre frequentemente. Não se deve evitar uma gravidez desejada, porém a mulher portadora da doença deve ter ciência que estará propensa ao abortamento ${ }^{[27]}$.

\subsection{O traço falciforme}

$\mathrm{O}$ traço falciforme é caracterizado pela presença de hemoglobina $\mathrm{S}$ em heterozigoze ( $\mathrm{Hb}$ AS) estando presente em percentual que varia de 22 a $45 \%$ da hemoglobina total ${ }^{[28]}$. A prevalência deste traço é de aproximadamente 8 a $9 \%$ nos negros americanos e 25 a $30 \%$ nas populações africanas ${ }^{[29]}$. Os indivíduos heterozigotos somam aproximadamente 2,5 milhões nos Estados Unidos e 30 milhões no mundo, já no Brasil segundo a agência nacional de vigilância sanitária (ANVISA) cerca de 2 milhões de pessoas são portadoras do traço falciforme ${ }^{[30]}$.

O traço falciforme raramente está associado a manifestações clínicas ou hematológicas significantes. Os indivíduos não apresentam anemia com a morfologia e a sobrevida das hemácias normais, portanto assumem o caráter de condição benigna ${ }^{[31]}$.

Apesar de os indivíduos heterozigotos normalmente não apresentarem evidentes manifestações clínicas da doença, existem relatos de complicações e até mesmo de morte súbita em portadores expostos a condições de baixa tensão de oxigênio como anestesia geral, mergulho, voo em aviões despressurizados, esforços físicos extenuantes, infecções respiratórias graves, insuficiência cardíaca respiratória e episódios de acidose. 
Todos são sintomas que podem levar à falcização das hemácias, causando complicações vasculares, complicações renais e do trato urinário ${ }^{[32]}$.

A principal importância do diagnóstico do traço falciforme está associada a probabilidade de nascimento de futuras crianças com a doença na forma homozigótica, uma vez que os portadores do traço falciforme têm o direito de serem informados, por meio do aconselhamento genético, a respeito dos aspectos hereditários e das demais conotações clínicas dessa doença.

O objetivo do aconselhamento genético é o de permitir aos indivíduos ou às suas famílias tomar decisões conscientes e equilibradas a respeito da procriação para serem alertados com relação aos problemas acarretados pela doença. Assim, principalmente os casais de risco estarão conscientes das chances em $25 \%$ de nascimento de uma criança homozigota, e também saberão da importância da realização precoce de exames laboratoriais na criança, melhorando a expectativa e qualidade de vida dela ${ }^{[33]}$.

\subsection{Prevalência da anemia falciforme nos centros de hemoterapia}

Um dos maiores estudos foi realizado com 101.000 amostras de sangue de 65 cidades de todas as regiões brasileiras, mostrando que a prevalência da $\mathrm{Hb}$ AS é maior na região norte $(4,49 \%)$ e decresce gradativamente em direção ao sul; nordeste $(4,05 \%)$, centro-oeste $(3,11 \%)$, sudeste $(1,87 \%)$ e sul $(1,87 \%)$. No geral a prevalência do traço falciforme na população brasileira foi de $2,1 \%$, entre pessoas de cor branca a prevalência foi de $1,18 \%$ e entre pessoas de cor negra foi de $4,87 \%^{[34]}$.

Investigou-se a presença da $\mathrm{Hb}$ AS em 250 doadores de sangue de Campinas/SP e foi encontrada uma prevalência de $2 \%{ }^{[35]}$.

Em 23.981 doadores de sangue da região de Uberlândia/MG foram encontrados $3,42 \%$ de portadores de hemoglobinopatias, sendo 2,48\% de $\mathrm{Hb} \mathrm{AS}^{[36]}$. 
Na Universidade Estadual de São Paulo em São José do Rio Preto/SP, de 262 doadores de sangue, treze apresentaram hemoglobinas anormais, dos quais dois apresentaram $\mathrm{Hb} \mathrm{AS}^{[37]}$.

Em Bragança Paulista/SP observou-se uma prevalência de 1,68\% de hemoglobinopatias de um total de 1.846 doadores de sangue e destes, 1,13\% tinham traço falciforme ${ }^{[38]}$.

Verificou-se uma prevalência de 1,39\% de $\mathrm{Hb}$ AS em 6.237 doadores de sangue de Londrina/ $\mathrm{PR}^{[39]}$.

Em Caxias do Sul/RS, de 608 amostras de sangue foram detectados sete doadores afetados com hemoglobinas anormais e apenas um com $\mathrm{Hb} \mathrm{AS}^{[40]}$.

Consequentemente, a realização da triagem dos portadores do traço falciforme nos bancos de sangue beneficia simultaneamente doador e receptor ${ }^{[41]}$. Com relação aos receptores o traço falcêmico é muito predominante e a chance de encontrar um receptor de sangue com essas características é muito grande, o que diminuiria a eficácia de uma transfusão. Já o benefício da triagem para os doadores de sangue se dá exatamente pela possibilidade de identificação do traço falciforme juntamente com o aconselhamento genético, do mesmo modo que a detecção de indivíduos heterozigotos é de extrema importância para a saúde pública, pois, além de ser possível fonte de novos heterozigotos, podem originar indivíduos homozigotos que precisam de tratamento precoce ${ }^{[42]}$.

$\mathrm{O}$ sangue com $\mathrm{Hb} \mathrm{S}$ não é recomendado para utilização em exsanguineotransfusões em recém-nascidos, crianças com hipoxemia, pacientes submetidos à cirurgia, acidose grave e pacientes com hemoglobinopatias ${ }^{[41]}$.

\subsection{Diagnóstico da anemia falciforme}

A urgente necessidade de desenvolver um diagnóstico de baixo custo para a AF há muito tempo foi reconhecida como prioridade pela Organização Mundial de Saúde ${ }^{[7]}$. 
Na década de 1950 foi observada uma grande diminuição da solubilidade da $\mathrm{Hb} \mathrm{S}$ em tampão fosfato concentrado ${ }^{[43]}$. Este modelo foi depois desenvolvido nos finais dos anos setenta e início dos anos oitenta ${ }^{[44-46]}$. Estes autores mostraram que, em alta concentração de tampão fosfato (1-1,8 M), a solubilidade de $\mathrm{Hb} \mathrm{S}$ pode ser baixada por aproximadamente três ordens de magnitude (em 1,8 M fosfato) em comparação com as condições fisiológicas $^{[45]}$. Além disso, eles mostram que a $\mathrm{Hb} \mathrm{S}$ polimeriza com um tempo claro de atraso (um período em que os polímeros não são detectados e que é seguido por um crescimento exponencial). Em 2000, foi relatado que, com base em observações usando microscopia crioeletrônica, os polímeros de $\mathrm{Hb} \mathrm{S}$ em 1,5 M de fosfato são idênticas às do fosfato $0,05 \mathrm{M}^{[47]}$.

Atualmente os métodos de diagnóstico da anemia falciforme vão desde eletroforese de hemoglobina $(\mathrm{EHG})^{[48]}$, focalização isoelétrica $(\mathrm{IEF})^{[49,50]}$ como cromatografia líquida de alta eficiência $(H P L C)^{[51]}$. Para tanto é necessário que existam laboratórios clínicos equipados com instrumentos especializados e técnicos altamente treinados, porém esses recursos não estão disponíveis em lugares com baixo índice de desenvolvimento ou pobreza acentuada incluindo locais de difícil acesso ${ }^{[52]}$. Além disso, a necessidade de transportar as amostras de sangue de um ponto isolado do Brasil até um laboratório centralizado e equipado com tais tecnologias torna o diagnóstico definitivo da anemia falciforme quase impossível ${ }^{[48]}$.

Antigamente existiam testes que utilizavam a saponina para lisar as hemácias do sangue do paciente em meio a um tampão fosfato, fazendo com que todos os tipos de hemoglobinas fossem liberadas em solução, e logo em seguida apenas a hemoglobina S, cuja estrutura é anormal, fosse desoxigenada na presença de hidrossulfito de sódio. Devido a este processo, bioquímico apenas qualitativo, a hemoglobina $S$ poderia ser "visualizada a olho nú", devido a turbidez da solução ocasionada pela reação bioquímica do meio com a hemoglobinas. Esta polimerização não era visualizada imediatamente podendo ser identificada até 1 hora depois do ensaio experimental ${ }^{[53,54]}$.

Atualmente observou-se que a insolubilidade da $\mathrm{Hb} \mathrm{S}$, em tampão fosfato concentrado 2,3 mol L ${ }^{-1}$, que tem sido referenciada por um grupo de pesquisadores de Tulane University nos Estados Unidos é uma das ferramentas auxiliares na detecção não só qualitativa como quantitativa desta hemoglobina. Este grupo utiliza um kit comercial para 
diagnóstico da anemia falciforme, porém é um material que se torna caro quando importado, pois além de conter tampão fosfato de potássio altamente concentrado ainda compõe um agente dispersante e/ou detergente (saponina); um agente redutor (hidrossulfito de sódio) e um conservante (2-cloroacetamida). O diferencial deste produto é o baixo custo final e o resultado qualitativo pode ser visualizado na hora em papel cromatográfico. Com esse tipo de método o resultado pode ser quantificado através de programas computacionais específicos ${ }^{[55]}$.

Portanto, antigamente o teste de solubilidade de $\mathrm{Hb}$ mesmo sendo de baixo custo e rápido era capaz de detectar hemoglobina $S$, mas não se podia distinguir entre traço e doença e ao longo do tempo algumas modificações foram realizadas nos experimentos de solubilidade convencionais e com a ajuda de programas computacionais os testes estão sendo aperfeiçoados ${ }^{[56]}$. Com novas modificações deste teste, sugeridas por nosso grupo de pesquisa, em qualquer lugar carente do Brasil, principalmente nos sertões, poderá ser feito o rastreamento de doentes.

\subsection{Diagnóstico do traço falciforme versus centros de hemoterapia}

O diagnóstico das hemoglobinas anormais passou a ser importante para os centros de hemoterapia a partir do momento em que a triagem de hemoglobinopatias nos doadores de sangue do Brasil tornou-se obrigatória através da resolução 153/04 de 2004 ${ }^{[57]}$. Essa resolução é concomitante com a necessidade de melhorar a qualidade do sangue a ser transfundido, mas apesar disso ela não indica o método de diagnóstico de detecção que deve ser realizado para seu cumprimento.

Os portadores do traço falciforme são hematologicamente saudáveis e aptos à doação de sangue, mas esse sangue possui utilização restrita tornando o diagnóstico desta

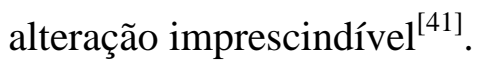

Uma grande variedade de testes qualitativos e quantitativos permitem a detecção do traço falciforme. Entre os testes qualitativos, era feito o teste de solubilidade, no qual as hemácias eram lisadas e a $\mathrm{Hb} \mathrm{S}$ reduzida pelo ditionito de sódio; por ser 
insolúvel, ela forma polímeros de deoxi-Hb S e turva a solução, enquanto que as soluções contendo outras hemoglobinas permanecem ${ }^{[58]}$. Outro teste qualitativo era o de falcização, este teste utilizava o metabissulfito de sódio como substância redutora que em contato com as hemácias extrai o oxigênio, levando as hemácias com $\mathrm{Hb} \mathrm{S}$ a assumir o formato de foice, verificado pela observação das hemácias ao microscópio.

Vários outros testes são comercializados na forma de "kit", entre eles o teste de gel-centrifugação, que se baseia no mesmo princípio da falcização "in vitro" e utiliza agente redutor e cartão com gel que retêm as hemácias falcizadas, ficando estas suspensas no microtubo após a centrifugação ${ }^{[59]}$.

A eletroforese de hemoglobina em fita de acetato de celulose ou em filme de agarose é um teste amplamente conhecido, podendo ser tanto qualitativo quanto quantitativo. A eletroforese se baseia na diferente mobilidade eletroforética das hemoglobinas carregadas eletricamente permitindo a separação das bandas de migração de hemoglobinas. Como a hemoglobina é uma proteína carregada negativamente, as proteínas migram para o pólo positivo. As diversas hemoglobinas com defeitos estruturais causados por substituições de aminoácidos de diferentes pontos isoelétricos resultam na migração de diferentes mobilidades eletroforéticas.

Outras técnicas quantitativas têm sido utilizadas, como eletroforese por focalização isoelétrica (IEF), Cromatografia Líquida de Baixa Pressão (LPLC) e Cromatografia Líquida de Alta Performace (HPLC) ${ }^{[60]}$. Muitos trabalhos mostram comparações entre os métodos de triagem de hemoglobinopatias. Estas comparações permitem uma análise dos métodos para determinar a padronização de uma técnica para a triagem nos doadores de sangue, principalmente pela necessidade de utilização de diferentes técnicas nos centros de hemoterapia do Brasil.

Comparando o teste de solubilidade com eletroforese de hemoglobina em 619 indivíduos, foram encontradas 130 amostras positivas no teste de solubilidade e todas foram confirmadas por eletroforese, sendo que o teste de solubilidade para $\mathrm{Hb} \mathrm{S}$ foi definitivo em 616 amostras, as três amostras restantes eram de recém-nascidos, o que tornou a detecção da $\mathrm{Hb} \mathrm{S}$ prejudicada, devido a ausência de produção da $\mathrm{Hb} \mathrm{S}$ antes do sexto mês de vida dos recém nascidos ${ }^{[61]}$. 
Foram comparados também quatro métodos de detecção da $\mathrm{Hb} \mathrm{S}$ : eletroforese de hemoglobina, teste de falcização com metabissulfito de sódio, teste de solubilidade com tampão fosfato e Sickledex reagent. Eles utilizaram 110 amostras de sangue e obtiveram concordância de resultados em todas as amostras, sendo que três amostras eram $\mathrm{Hb} \mathrm{AS}$,

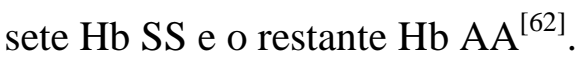

Comparou-se o teste de solubilidade de tampão fosfato com o teste de falcização com metabissulfito de sódio e o resultado foi confirmado com eletroforese de hemoglobina. O teste de falcização apresentou 5,3\% de resultados falso-negativos nas amostras contendo $\mathrm{Hb} \mathrm{S}$ comparado com o teste de solubilidade em 418 amostras. O teste de solubilidade apresentou $1,1 \%$ de amostras falso-negativas para $\mathrm{Hb} \mathrm{S}$ e $0,7 \%$ de falsopositivas em 1205 amostras testadas em eletroforese de hemoglobina ${ }^{[63]}$.

Foi relatado $100 \%$ de compatibilidade entre os testes de solubilidade e eletroforese de hemoglobinas em 629 amostras de sangue, sendo 190 com $\mathrm{Hb}$ S, com apenas um caso falso-positivo em paciente com policitemia ${ }^{[64]}$. Outra análise comparativa também foi realizada e comparou-se o teste de solubilidade, o de falcização e o de gelcentrifugação e foi observado que não há discrepância entre os métodos em 28 amostras de $\mathrm{Hb}$ AS analisadas de um total de 836 amostras estudadas de pacientes de pré-natal ${ }^{[59]}$.

Foram relatados resultados $100 \%$ compatíveis entre as técnicas de solubilidade e de gel-centrifugação em 5.416 doadores de sangue, destes 50 eram amostras com Hb AS. Neste mesmo estudo os autores compararam as técnicas de solubilidade, gel-centrifugação e eletroforese de hemoglobina em 213 negros e descendentes de negros e encontraram 18 portadores de $\mathrm{Hb} \mathrm{AS}$, sendo que esta amostra também apresentou $100 \%$ de compatibilidade entre as técnicas ${ }^{[41]}$.

Entretanto, o estudo realizado com 3.246 indivíduos na Índia, detectou pelo teste de solubilidade 871 portadores de $\mathrm{Hb} \mathrm{S}$ dos 932 detectados por HPLC e eletroforese, o teste de solubilidade apresentou sensibilidade total de 93,8\%, especificidade de $100 \%$, sendo então que 61 portadores de $\mathrm{Hb} \mathrm{S}$ foram classificados como negativos, mostrando assim que o teste de solubilidade em grandes amostras deixa de detectar alguns casos ${ }^{[65]}$. 
Portanto, pode-se observar, através de vários estudos, que o uso do método da solubilidade para a detecção da $\mathrm{Hb} \mathrm{S}$ nos centros de hemoterapia apresenta casos falsos negativos e falsos positivos. Apesar disso, deve-se levar em consideração o fato desse teste exigir pouco tempo, ser de fácil realização, sem necessitar de muito treinamento de pessoal e principalmente por ter um custo bem mais acessível facilitando a sua realização em comunidades pobres e isoladas.

Outro estudo realizado avaliou um kit que utiliza a tecnologia de gelcentrifugação. Foram analisadas 131 amostras de sangue contendo hemoglobinas normais e variantes (75 amostras contendo $\mathrm{Hb} \mathrm{S}$ ) determinadas por várias técnicas padronizadas como eletroforese alcalina e ácida, HPLC e teste de solubilidade. Avaliaram tanto o kit para um teste quanto o para múltiplos testes. O kit para um teste foi realizado para todas as amostras e nenhum resultado positivo foi encontrado, inclusive para aquelas amostras que continham mais do que $95 \%$ de $\mathrm{Hb} \mathrm{S}$, sendo esse problema atribuído ao agente redutor. $\mathrm{O}$ kit para múltiplos testes (50 amostras) detectou algumas amostras positivas, assim, de 30 amostras de pacientes com anemia falciforme ( $\mathrm{Hb} \mathrm{SS}$ ), quatro foram negativas e as outras apresentaram resultados mais fracos do que o esperado. $\mathrm{O}$ resultado do teste para as amostras de pacientes com traço falciforme ( $\mathrm{Hb} \mathrm{AS}$ ) também foram mais fracas do que o esperado e 13 das 34 amostras foram negativas ${ }^{[66]}$.

Quando os testes foram repetidos, os resultados obtidos não foram os mesmos e também não houve correlação entre a intensidade da reação e a quantidade de $\mathrm{Hb} \mathrm{S}$. Com esses resultados, o estudo concluiu que o desempenho do kit foi bastante insatisfatório, mostrando-se insensível e não confiável para detectar as amostras com Hb S.

Como observado há necessidade de maiores estudos sobre as técnicas que melhor se adaptem a realidade dos centros de hemoterapia, mas mesmo assim existe uma gama de métodos de diagnóstico para os grandes centros divergindo da realidade dos locais mais afastados do país, locais estes em que vivem pessoas sem diagnóstico por falta de recursos e consequentemente sem tratamento. 


\subsection{A cromatografia e a microfluídica como alternativas no diagnóstico}

A cromatografia é uma técnica que foi relatada cientificamente há pouco mais de cem anos e baseia-se na migração de componentes de uma mistura entre duas fases: a fase estacionária que retém elementos e a fase móvel que conduz a mistura por meio de um soluto através da fase estacionária. Pode ser utilizada para purificação e detecção de substâncias ou auxiliar na separação de substâncias indesejáveis.

A cromatografia em papel é uma técnica de partição líquido-líquido, estando uma parte fixada a um suporte sólido. Baseia-se na diferença de solubilidade das substâncias entre duas fases imiscíveis ${ }^{[67,68]}$. A cromatografia em papel é uma das técnicas mais simples e que requer menos instrumentos para sua realização, sendo muito útil para a separação de compostos polares, FIG. 3.3. Devido à alta precisão e confiabilidade dessas técnicas, elas são muito utilizadas na detecção ou separação de substâncias que estão em pequenas quantidades em uma mistura.

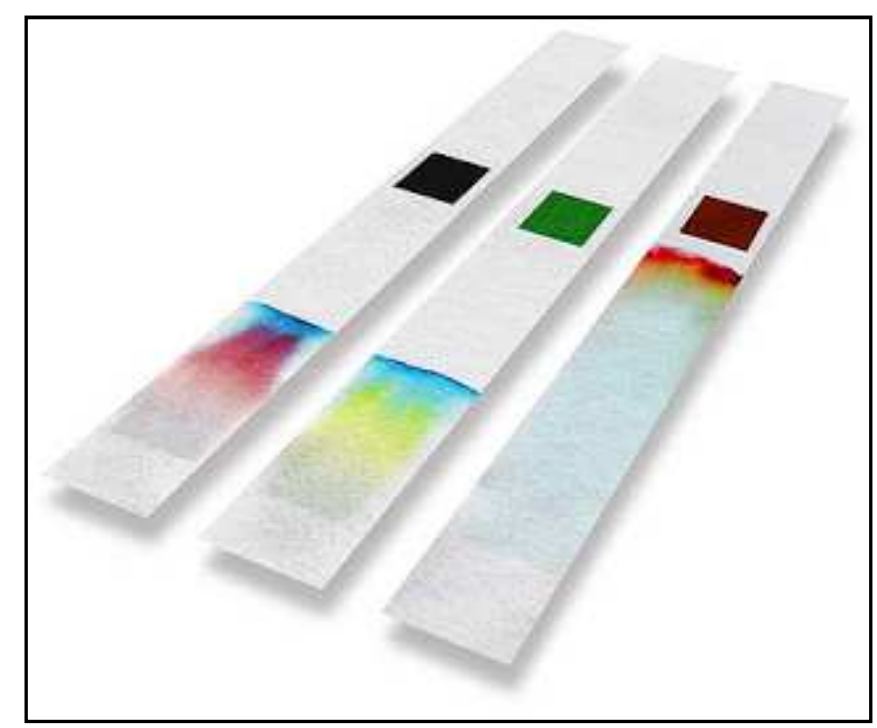

FIGURA 3.3. Papel filtro após experimento para identificação de diferentes tipos de tinta para canetas hidrográficas. Figura adaptada de: http://www.engquimicasantossp.com.br/cromatografia-em-papel.html. (acessada em 20/07/2014). 
O papel de cromatografia é composto por moléculas de celulose que possuem afinidade pela água, mas muito pouca afinidade pela fase orgânica, atuando como suporte inerte contendo a fase estacionária aquosa (polar). À medida que o solvente contendo o soluto flui ao longo do papel, uma partição deste composto ocorre entre a fase móvel (pouco polar) e a fase estacionária (polar). Com o fluxo contínuo de solvente, o efeito desta partição entre as fases móvel e estacionária possibilita a transferência do soluto do seu ponto de aplicação no papel para outro ponto localizado a alguma distância do local de aplicação no sentido do fluxo de solvente ${ }^{[69]}$.

$\mathrm{Na}$ área médica a cromatografia tem grande utilização na toxicologia, seja para monitorar o uso de medicamento ou para o seu uso na ciência forense, dosando drogas de abuso e auxiliando a elucidar crimes ${ }^{[70]}$. Atualmente podemos constatar que esta técnica começou a ser empregada para a diferenciação das hemoglobinopatias como citado neste trabalho.

Já a microfluídica é uma atividade emergente e se baseia no uso e controle de pequenos volumes (líquidos ou gasosos) ${ }^{[71]}$. Durante a década de 1980 , o progresso em microfluídos se baseou no desenvolvimento de microválvulas, microsensores e "micropumps". A figura a seguir ilustra basicamente um dos mecanismos dos microchips.

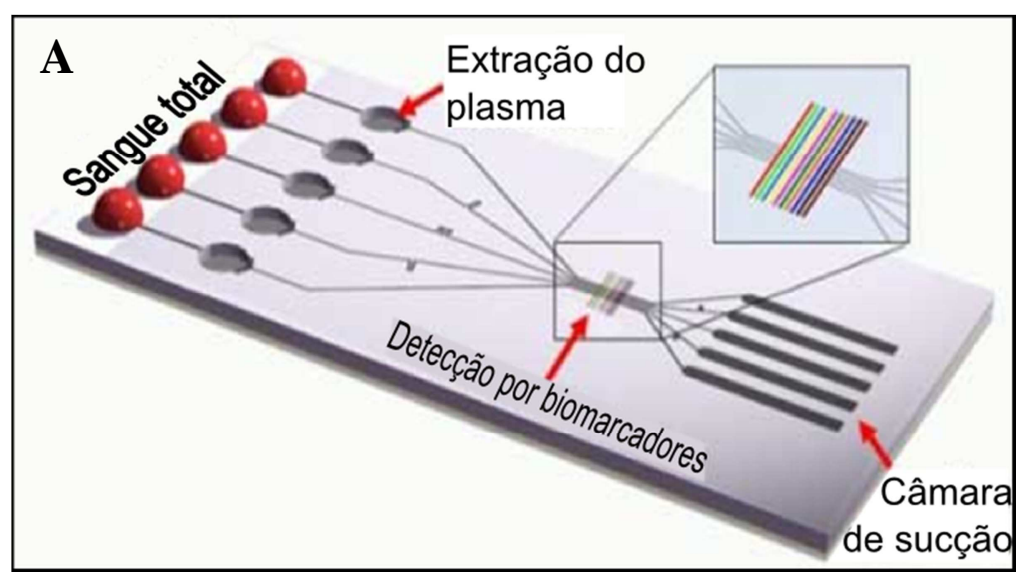




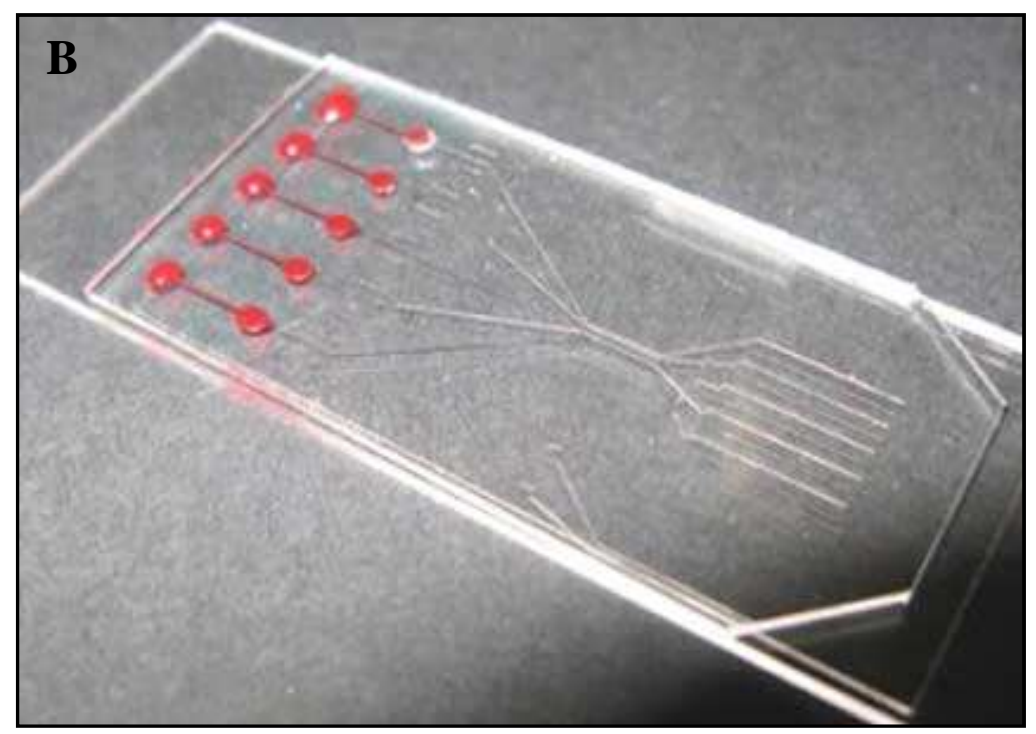

FIGURA 3.4. (A): representação de um chip microfluídico. O sangue flui da esquerda para a direita, os glóbulos vermelhos e a série branca escoam até um dispositivo de detecção de biomarcadores enquanto o plasma é extraído. (B): foto do chip $(2,5 \mathrm{~cm} \times 5 \mathrm{~cm})$. Créditos: Ivan Dimov/Uc Berkeley. Figura adaptada de: http://lqes.iqm.unicamp.br/canal_cientifico.html. (acessada em 20/07/2014).

Os campos de aplicação da microfluídica incluem às ciências da vida e a química $^{[72]}$ e têm recebido atenção devido ao desenvolvimento em biologia e biotecnologia que permitem manipulação celular, detecção de volumes insignificantes ${ }^{[73]}$, demanda por dispositivos portáteis e de baixo custo ${ }^{[74]}$, potencial de microssistemas para o estudo de reações fundamentais da física, química e biologia. Além da interessante possibilidade de utilização de papéis convencionais como matéria prima ${ }^{[75]}$.

Entre as possíveis aplicações da microfluídica também pode-se citar todas aquelas executadas em sistemas convencionais: separação de biomoléculas como proteínas, peptídeos, sequenciamento de DNA, ensaios enzimáticos, imunoensaios, aminoácidos, aminas biogênicas, entre outros. Além disso, a versatilidade inerente à construção dos microdispositivos permite a execução de experimentos baseados em imobilização de biomoléculas e análises integrando reações químicas em várias etapas ${ }^{[76]}$. 
Da mesma forma que os microchips eletrônicos revolucionaram o universo dos computadores e da eletrônica, os microchips analíticos têm revolucionado a química analítica nos últimos anos ${ }^{[77-79]}$. Inicialmente a principal razão para a miniaturização era aumentar o desempenho analítico mais do que reduzir seu tamanho. No entanto, com a mudança da escala macro para a micro, outras vantagens foram obtidas, como a redução do volume de reagentes e amostras (da ordem de pL-nL), baixo custo de fabricação e análise em tempo reduzido ${ }^{[80]}$.

O primeiro dispositivo analítico miniaturizado foi um sistema de cromatografia em fase gasosa apresentado na década de $70^{[81]}$. Apesar da capacidade de realizar rápidas separações, o primeiro microdispositivo não foi prontamente aceito pela comunidade científica, devido à falta de experiência tecnológica em métodos de separação. Com isso, na década de 80, pesquisas relacionadas à miniaturização ficaram limitadas ao desenvolvimento de micro-bombas, micro-válvulas e sensores químicos ${ }^{[82]}$.

O renascimento dos microdispositivos analíticos ocorreu no início da década de 90, com a apresentação de um microssistema para cromatografia em fase líquida ${ }^{\left[{ }^{[3]}\right.}$. Simultaneamente à apresentação deste microdispositivo, foi proposto o conceito de microssistemas para análises totais, ou simplesmente $\mu$ TAS (Micro Total Analysis Systems $)^{[84]}$. Com o desenvolvimento dos $\mu \mathrm{TAS}$, tornou-se possível integrar várias etapas analíticas como introdução da amostra, pré-tratamento da amostra, reações químicas, separação analítica e detecção em um único dispositivo ${ }^{[80,84]}$.

Devido à ideia de inserir várias etapas em um único dispositivo (chip), os $\mu$ PADs (Paper-based Analytical Devices), dispositivos cuja matéria prima é o papel, foram também desenvolvidos e denominados "lab-on-a-chip" (LOC) ${ }^{[85]}$. Portanto, os $\mu$ TAS e os $\mu \mathrm{PADs}$ transformam informações químicas em sinais elétricos ou ópticos, possibilitando uma fácil automação.

Estes aspectos se tornaram relevantes para o campo clínico e ambiental em que o termo "point-of-care" vem sendo utilizado ${ }^{[85,86]}$. Todos estes fatores, aliados à portabilidade, impulsionaram o desenvolvimento explosivo e maciço dos sistemas analíticos em micro-escala nos últimos anos ${ }^{[78,79]}$. 
Portanto, a técnica de cromatografia por papel empregada pelo grupo de pesquisadores dos EUA e pelo nosso grupo também é considerada uma técnica de microfluídica devido à detecção de volumes cada vez menores. Recentemente foi utilizado um ensaio colorimétrico microfluídico, de sangue total, em papel de cromatografia ${ }^{[87]}$, inspiração deste trabalho, e este novo grupo de ferramentas analíticas de diagnóstico é hoje também chamada de tecnologia de dispositivos $\mu \mathrm{PADs}^{[88]}$.

\subsection{Terras Raras como marcadores para diagnósticos}

A Comissão de Nomenclatura em Química Inorgânica da IUPAC (International Union of Pure and Applied Chemistry) recomenda a expressão "metais de terras raras" para os elementos Sc, Y e de La a Lu (a palavra "rara" refere-se ao processo de difícil separação destes elementos). Enquanto que o termo "série do lantânio" é reservado para os elementos de número atômico de 57 a 71 ( La a Lu) a expressão "série lantanídica" é ainda mais restrita porque exclui o elemento lantânio, indo do elemento de número atômico 58 ao elemento de número atômico 71 .

O principal fator que distingue os íons $\mathrm{Ln}^{3+}$ dos outros íons metálicos é o fato de que seus elétrons de valência se encontram nos orbitais $4 \mathrm{f}$, que são mais internos e estão blindados pelas camadas $5 \mathrm{~s}$ e 5p, conferindo-lhe uma química de natureza iônica. Fatores eletrostáticos e considerações estéricas parecem ser mais importantes na determinação da estabilidade e da estrutura e química dos complexos de lantanídeos do que as interações entre orbitais do metal e do ligante ${ }^{[89,90]}$.

Materiais luminescentes são compostos capazes de emitir radiações quando submetidos à excitação por radiação ultravioleta, raios $\mathrm{X}$, bombardeamento de elétrons, fricção ou alguma outra forma de excitação ${ }^{[91,92]}$.

Os íons lantanídeos absorvem radiação eletromagnética na região espectral que se estende do ultravioleta próximo, passando pelo visível, até o infravermelho próximo. As transições eletrônicas que ocorrem nestas regiões espectrais como resultado das subcamadas $4 \mathrm{f}$ incompletas, são as transições internas $4 \mathrm{f} \rightarrow 4 \mathrm{f}$, transição 
$4 \mathrm{f}^{n} \rightarrow 4 \mathrm{f}^{n-1} 5 \mathrm{~d}$, ou transição de transferência de carga dependendo do centro metálico e de seu estado de oxidação, bem como do ligante em questão ${ }^{[91]}$.

Os íons lantanídeos podem ser considerados como ácidos "duros" de acordo com a classificação de PEARSON ${ }^{[92]}$. Íons que apresentam esta propriedade tendem a ligar-se às bases "duras", especialmente aquelas que contêm oxigênio e/ou nitrogênio como átomos doadores.

A blindagem efetiva dos elétrons $4 \mathrm{f}$ pela camada (5s $2 \mathrm{p} 6$ ) faz com que os estados das configurações $4 \mathrm{fn}$ sejam pouco afetados pela vizinhança química ao redor dos íons lantanídeos tripositivos ${ }^{[93]}$. O orbital $4 \mathrm{f}$ das espécies no estado sólido mantém, em grande parte, seu caráter atômico, facilitando a interpretação dos níveis de energia através de seus espectros.

A fotoativação conduz moléculas a estados eletrônicos excitados e estas, ao voltarem para o estado fundamental, são desativadas por processos físicos e químicos. Os processos físicos podem ser divididos em radiativos e não radiativos e classificados como processos de relaxação intramolecular ou intermolecular. Entre os processos radiativos incluem-se a luminescência (fosforescência e fluorescência) e transferência de energia. Nos processos não radiativos estão incluídos a relaxação vibracional (molecular e de rede), a conversão interna, o cruzamento intersistema e as transferências de energia por ressonância ou troca ${ }^{[94-96]}$.

Quando um quantum de luz incide sobre uma molécula este é absorvido em cerca de $10^{-15}$ segundos e assim ocorre uma transição ao estado eletrônico mais alto. Esta absorção de radiação é altamente específica, sendo absorvida apenas por uma estrutura característica.

Neste processo, a molécula é levada a um estado singleto excitado S1, S2, S3, etc. Estas transições de absorção normalmente originam-se no nível vibracional mais baixo do estado eletrônico fundamental ${ }^{[97]}$. As multiplicidades de estados são importantes nos processos de relaxação radiativa uma vez que a natureza do processo de emissão depende delas. 
A molécula pode estar no estado excitado durante um período de $10^{-4}$ segundos, no qual qualquer energia em excesso é rapidamente dissipada e o nível vibracional mais baixo do estado singleto excitado (S1) é atingido. Se a energia absorvida na transição não for dissipada por colisões com outras moléculas, o elétron retorna ao estado fundamental (S0) com emissão de energia. Geralmente, quando os estados eletrônicos, onde se origina e termina a emissão, tem a mesma multiplicidade $(\Delta S=0)$, a luminescência é chamada de fluorescência. Este processo, comumente, ocorre entre o primeiro estado singleto excitado (S1) e o singleto fundamental (S0). Como parte da energia absorvida é perdida no breve período anterior à emissão, a energia emitida tem um comprimento de onda maior que o comprimento de onda da energia absorvida.

Se os estados nos quais a emissão se inicia e termina apresentam multiplicidade de spin diferente $(\Delta S \neq 0)$, o processo é chamado fosforescência. Tal fenômeno envolve um cruzamento intersistema (processo não radiativo), visto que a transição do estado fundamental ao estado tripleto excitado é proibida (altamente improvável), com emissão do primeiro estado tripleto excitado, $\mathrm{T} 1$, ao estado singleto fundamental, $\mathrm{S} 0^{[96-98]}$.

Para os processos não radiativos envolvendo estados eletrônicos diferentes duas denominações são utilizadas: conversão interna, se os estados têm a mesma multiplicidade de spin e, conversão intersistema, para o estado com multiplicidades de spin diferentes.

Estes processos dependerão das posições relativas dos diferentes níveis de energia eletrônica em energia vibracional (relaxação vibracional).

É comum se fazer a distinção entre fluorescência e fosforescência baseando-se no tempo de vida da emissão. Como as transições permitidas ocorrem somente para $\Delta S=0$, tempos de vida de emissão da ordem de $10^{-10}$ a $10^{-7}$ segundos são observados na fluorescência, enquanto que tempos de vida da ordem de $10^{-3}$ a 10 segundos são observados na fosforescência ${ }^{[94,96-98]}$. O critério que utiliza regras de seleção é preferencialmente empregado, ou seja, iguais multiplicidades de spin (fluorescência) e diferentes multiplicidades de spin (fosforescência), embora o termo geral luminescência evite confusões ${ }^{[94]}$. 
Emissões de estados eletrônicos diferentes do estado excitado mais baixo de uma dada multiplicidade são raros em sistemas orgânicos e inorgânicos, ocorrendo predominantemente desativação não radiativa ${ }^{[99]}$.

Comparações entre sistemas orgânicos e inorgânicos foram feitos tanto para processos radiativos como para processos não radiativos. Quando não há variação nas multiplicidades de spin as velocidades dos sistemas são semelhantes. Mas, se $\Delta S \geq 1$ as constantes de velocidade são muito diferentes. Estas diferenças se justificam pela relaxação das regras de seleção (principalmente a regra de spin), devido as constantes de acoplamento spin-órbita (íons metálicos que têm maiores número atômicos), que provocam misturas dos estados singleto e tripleto. Nos sistemas orgânicos que contêm átomos com baixos números atômicos os cruzamentos intersistema são formalmente proibidos ${ }^{[99]}$.

A luminescência dos íons $\mathrm{TR}^{3+}$ consiste na visualização de bandas de emissão finas (correspondentes às transições internas f-f-), do tipo espectros atômicos, pois os estados eletrônicos são minimamente afetados pela vizinhança química ao centro metálico, uma vez que os elétrons $4 \mathrm{f}$ são blindados pelo arranjo $5 \mathrm{~s}^{2} 5 \mathrm{p}^{6}$. Desta forma, as propriedades dos íons terras raras são quase sempre mantidas após a formação de compostos com ligantes orgânicos, ao contrário do que ocorre com os compostos de metais de transição. Os espectros de fluorescência comparam-se aos espectros de absorção, estando ambos ligados a esta blindagem experimentada pelos orbitais $4 \mathrm{f} \mathrm{e}$, portanto, nem todas as transições possíveis resultam em fluorescência, enfatizando a importância dos efeitos relacionados ao ambiente químico e os efeitos de simetria ${ }^{[100,101]}$.

Os íons $\mathrm{TR}^{3+}$, particularmente aqueles do meio da série, tais como samário, európio, térbio e disprósio, formam complexos que quando submetidos à excitação na região ultravioleta próxima frequentemente emitem na região do visível, devido às transições internas $\mathrm{f}-\mathrm{f}^{[101]}$.

A fluorescência característica dos quelatos de Terras Raras pode ocorrer a partir do ligante excitado perturbado pelo cátion; do cátion excitado perturbado pelo ligante; da transferência de energia intramolecular não radiativa do ligante excitado pelo cátion e posterior emissão ${ }^{[101,102]}$. 
A excitação eletrônica de compostos de terras raras ao estado singleto excitado mais baixo (S1) de um ligante resulta na observação de luminescência e, este fenômeno consiste de fluorescência molecular, fosforescência molecular e emissão correspondente às transições internas f-f, FIG. 3.5.

O processo de sensibilização da luminescência de compostos de coordenação de íons $\mathrm{TR}^{3+}$ foi reportado primeiramente em 1942, que demonstrou que sob excitação na região de absorção dos ligantes estes sistemas exibiam emissões características do íon metálico central ${ }^{[103]}$. Notou-se que um ligante orgânico apresentando alto coeficiente de absortividade molar, quando coordenado ao íon metálico é capaz de transferir energia eficientemente para o íon terra rara, intensificando sua luminescência. Além disso, o ligante pode ser escolhido no sentido de fornecer ao sistema determinada funcionalidade com desejadas propriedades, tais como: solubilidade, atividade eletroquímica, afinidade de ligação a outros sistemas moleculares, respostas a estímulos externos e etc ${ }^{[104]}$.

Nos estudos sobre os processos de transferência de energia intramolecular, três mecanismos pelos quais a energia absorvida pelo ligante pode ser transferida para $\mathrm{o} \mathrm{TR}^{3+}$ têm sido propostos ${ }^{[103,104]}$. Estes mecanismos estão ilustrados e descritos a seguir.

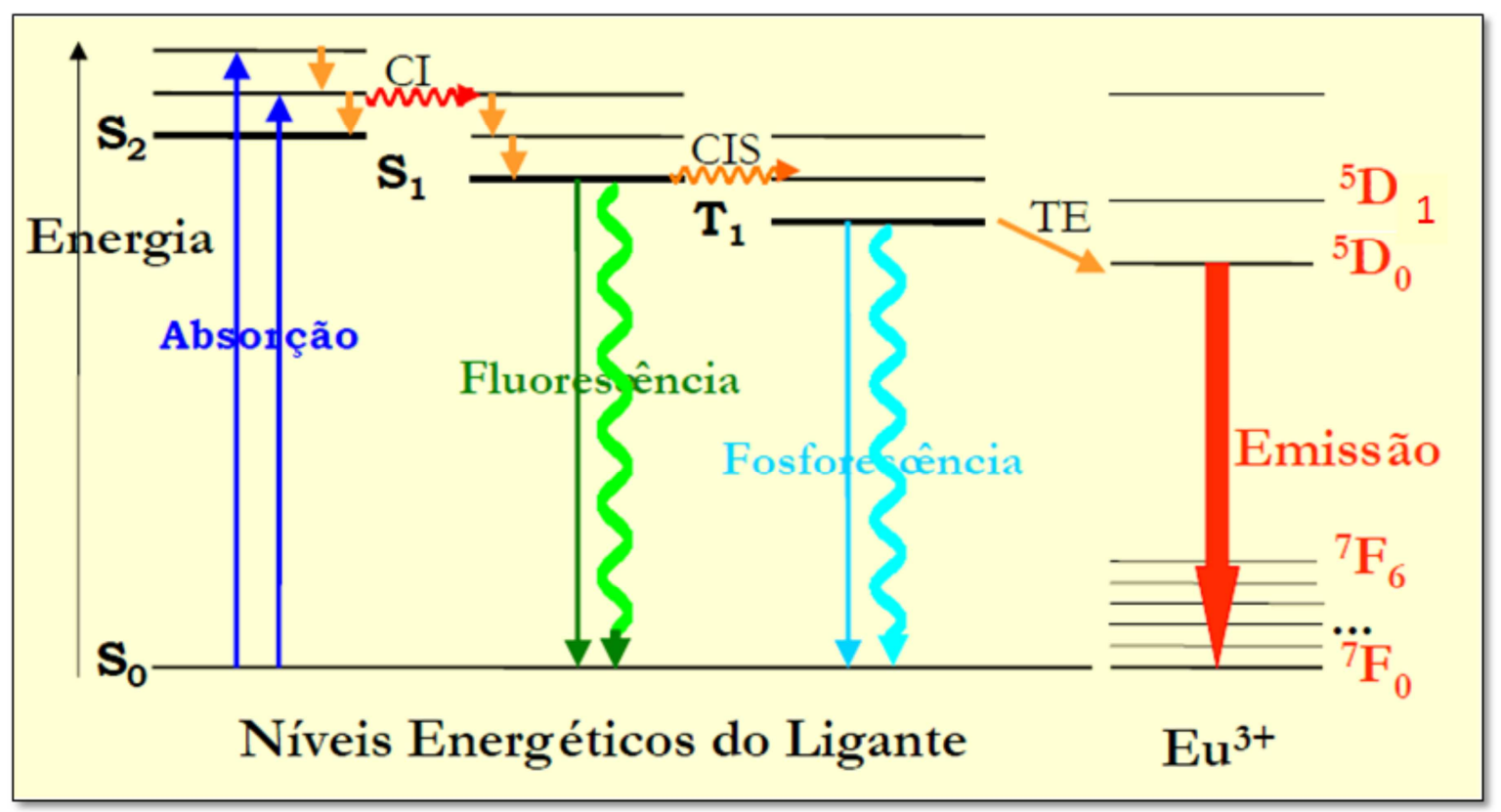

FIGURA 3.5. Representação esquemática (qualitativa) do mecanismo de transferência de energia entre um ligante orgânico e o íon $\mathrm{Eu}^{3+}(\mathrm{CI}=$ Conversão Interna/ CIS $=$ Cruzamento Intersistema/ $\mathrm{TE}=$ Transferência de Energia $)^{[105]}$. 
Mecanismo I - A energia é absorvida pelo ligante para o estado excitado (singleto, S1) que após cruzamento intersistema para o estado tripleto (T), ocorre transferência de energia Ligante $-\mathrm{TR}^{3+}$ a partir do primeiro estado excitado $\mathrm{T}$ para o nível emissor (E1) do íon $\mathrm{TR}^{3+}$. Posteriormente, ocorre emissão de luz através das transições intraconfiguracionais 4 fn característica do íon $\mathrm{TR}^{3+[106-108]}$.

Mecanismo II - Neste caso, o estado $\mathrm{T}$ não participa do processo de transferência de energia sendo considerado apenas a transferência de energia diretamente do estado excitado S1 para o nível emissor (E1) do íon $\mathrm{TR}^{3+[109]}$.

Mecanismo III - Observa-se que além dos níveis de energias já considerados (S1, T e E1), existe a participação de um nível excitado (E2) do íon $\mathrm{TR}^{3+}$ com energia maior do que a do estado T. O processo de transferência de energia é então descrito pelas seguintes etapas: i) transferência de energia do estado S1 para o nível excitado E2 do metal; ii) transferência de energia do nível $\mathrm{E} 2\left(\mathrm{TR}^{3+}\right)$ para o estado tripleto $\mathrm{T}$ do ligante e iii) transferência de energia do estado $\mathrm{T}$ para o nível $\mathrm{E} 1$ do íon $\mathrm{TR}^{3+[110]}$.

Como pode ser observado na FIG. 3.5, os estados eletrônicos do ligante, (antena) e dos íons terras raras podem ser descritos separadamente, desde que a interação covalente entre o ligante e o íon $\mathrm{TR}^{3+}$ seja muito fraca, conduzindo somente a pequenas misturas de seus estados.

Apesar do mecanismo I mostrar-se mais concordante com os resultados experimentais, a existência de estados $\mathrm{T}$ com energias acima do nível excitado do íon $\mathrm{TR}^{3+}$ pode promover uma transferência de energia $\mathrm{T} \rightarrow \mathrm{E} 2$. Deve-se considerar ainda que adicionalmente aos processos descritos nos mecanismos supracitados, outros processos fotofísicos podem ocorrer nos sistemas promovendo relaxações eletrônicas, dentre estes se destacam: fluorescência do ligante resultante de uma transição $\mathrm{S} 1 \rightarrow \mathrm{S} 0$; decaimento não radiativo via mecanismos de conversão interna do estado S1 para o estado S0; decaimento não radiativo do estado $\mathrm{T}$ excitado para o estado fundamental S0 via cruzamento intersistema e fosforescência via transição do estado tripleto para o estado fundamental S0. 
Pode-se notar que nos complexos com íons terras raras, a fosforescência dos ligantes sensibilizadores, antenas, é observada quando os níveis excitados do íon metálico central estão localizados energeticamente acima do primeiro estado excitado $\mathrm{T}$ do ligante (ex.: íon $\mathrm{Gd}^{3+}, 8 \mathrm{~S}_{7 / 2} \rightarrow 6 \mathrm{P}_{7 / 2} \sim 32.000 \mathrm{~cm}^{-1}$ ) ou quando os íons $\mathrm{TR}^{3+}$ não apresentam elétrons $4 f$ opticamente ativos (ex.: $\mathrm{La}^{3+} \mathrm{e} \mathrm{Lu}^{3+}$ ). No entanto, quando existe ligantes onde o estado $\mathrm{T}$ com energia acima dos níveis emissores dos íons $\mathrm{TR}^{3+}$ a transferência de energia intramolecular Ligante-Metal é geralmente operante resultando na luminescência oriunda do íon terra rara. Deve-se salientar que, sob excitação indireta,via ligante, a transferência de energia Ligante-Metal está intimamente relacionada com a posição dos estados $\mathrm{T}$ da antena e dos níveis excitados do íon $\mathrm{TR}^{3+[111]}$.

Do ponto de vista da luminescência do íon metálico, os íons $\mathrm{TR}^{3+}$ coordenados têm sido classificados em três grupos:

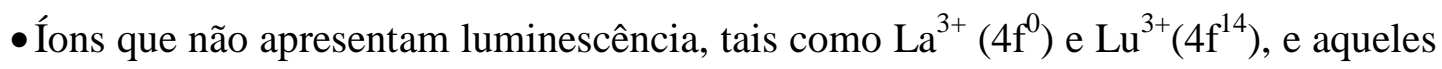
no qual este fenômeno é raramente observado por apresentarem os estados excitados em alta energia, $\mathrm{Gd}^{3+}\left(4 \mathrm{f}^{7}\right)$;

- Íons que exibem luminescência intensa por apresentarem níveis de energia abaixo dos estados tripletos dos ligantes e, adicionalmente, apresentam grande diferença de energia entre os níveis excitados e fundamentais $\left(\mathrm{Sm}^{3+}, \mathrm{Eu}^{3+}, \mathrm{Tb}^{3+}\right.$ e $\left.\mathrm{Dy}^{3+}\right)$;

- Aqueles íons, tais como: $\mathrm{Pr}^{3+}, \mathrm{Nd}^{3+}, \mathrm{Ho}^{3+}, \mathrm{Er}^{3+}, \mathrm{Tm}^{3+}$ e $\mathrm{Yb}^{3+}$, que exibem intensidades de luminescência muito fraca devido a grande contribuição dos processos não radiativos resultantes da pequena diferença entre as energias dos estados $^{[111]}$.

Já nos processos de transferência de energia intramolecular, para que o ligante seja considerado uma "antena eficiente", ou seja, um bom sensibilizador luminescente é necessário que ele contenha um grupo que contribua para sua alta absortividade (grupo cromóforo) e apresente condição de ressonância entre seus estados dos ligantes e os níveis emissores do íon terra rara. Adicionalmente, o ligante não pode apresentar canais de supressão de luminescência, tais como, modos vibracionais de alta frequência e estados eletrônicos com energia abaixo do nível emissor do íon $\mathrm{TR}^{3+}$. Neste contexto, várias 
classes de ligantes têm sido testadas como antenas, sendo os ânions $\beta$-dicetonatos os que apresentam maior interesse ${ }^{[12,113]}$.

O diagnóstico como um todo representa um mercado muito grande, bem estabelecido e em contínua expansão. Particularmente no clima atual de "prevenir ao invés de curar" a necessidade de se obter limites de detecção cada vez mais baixos em diversas áreas de aplicação soma-se a um requerimento para monitoramento contínuo e controle com baixo custo em áreas tradicionais ${ }^{[14]}$. Um dos maiores mercados diagnósticos do mundo é, sem dúvida, aquele com testes clínicos e dentro deste campo, os marcadores desempenham um papel chave.

Em termos gerais, como definição da IUPAC, um marcador ou rotulador ${ }^{[115]}$ é um composto químico que é distinguido pelo observador, mas não pelo sistema e que é usado para identificar um traçador ${ }^{[16]}$, que é um membro marcado, de uma população usada para medir certas propriedades inerentes àquela população. Resumidamente, biomoléculas como as proteínas, ácidos nucleicos, polissacarídeos ou lipídeos, marcadas com uma partícula luminescente ligam-se seletivamente a um antígeno específico, a um carboidrato ou a uma sequência de ácido nucleico fazendo com que os alvos biológicos sejam detectados ${ }^{[117]}$.

Em geral, os marcadores podem ser divididos em três grupos principais: marcadores radioativos, marcadores enzimáticos e marcadores luminescentes ${ }^{[118]}$.

Os marcadores radioativos são os menos acessíveis e tem a vantagem do não impedimento estérico. Eles proporcionam uma medida quase sem background, tornando estes marcadores muito sensíveis que mesmo quando em quantidades extremamente pequenas podem ser detectados. Infelizmente, esses marcadores possuem um tempo de utilização limitado devido ao decaimento radioativo. Além disso, o manuseio e a disposição do material radioativo requerem um alto grau de monitoramento e de segurança o que os torna caros.

As enzimas são os marcadores mais largamente difundidos, onde o tipo de ensaio enzimático mais conhecido é o ensaio ELISA. O ensaio enzimático tem uma alta sensibilidade desde que o produto detectável da reação seja continuamente produzido. A 
principal desvantagem dos ensaios enzimáticos são a necessidade da adição de reagentes, o requerimento de etapas de lavagens repetidas e a necessidade de um tempo de incubação que pode levar à desnaturação das proteínas. Finalmente, o uso de proteínas de cadeias longas pode causar impedimento estérico nos eventos de ligação.

Os marcadores luminescentes têm conquistado muita popularidade nos últimos anos. Eles possuem uma alta sensibilidade desde que cada evento de ligação continuamente gere um sinal devido à regeneração de fótons emitidos. Além disso, matrizes de marcadores luminescentes são comercialmente acessíveis em vários comprimentos de onda. Quando se utiliza um marcador luminescente, vários parâmetros podem ser medidos como a intensidade de luminescência, o tempo de vida e a anisotropia.

Um marcador luminescente ideal deve possuir as seguintes propriedades: absortividade molar e rendimento quântico alto para obtenção de uma alta intensidade de luz; fotoestabilidade; solubilidade em água; acessibilidade comercial a baixo custo; alta reatividade para perfazer ligações covalentes às proteínas; não interagir com qualquer espécie presente que leve à mudança nas propriedades fotofísicas como absortividade molar; tempo de vida ou rendimento quântico; absorbância máxima em uma longa faixa de comprimento de onda e que seja preferencialmente atóxico ${ }^{[18]}$.

Portanto, aplicações de alta tecnologia caracterizam uma nova era com produtos digitais contribuindo para a vida moderna. Os elementos de TR participam desta tecnologia com novos materiais e novas aplicações que permitem melhor eficiência, materiais de maior desempenho que satisfaz a demanda por produtos mais rápidos, menores e mais leves ${ }^{[119]}$.

A saúde e a tecnologia médica também estão se desenvolvendo em um ritmo acelerado. A comunidade científica está fazendo grandes avanços com a identificação de novas aplicações de compostos orgânicos e inorgânicos para o desenvolvimento de novas técnicas e máquinas para detectar, tratar doenças e monitorar a saúde humana.

Portanto, elementos de TR desempenham papel vital em conjunto com essas novas tecnologias tornando-se essenciais, por exemplo, para aparelhos de ressonância magnética, utilizados em imaginologia médica, em diagnósticos clínicos e nanotecnologia 
através de fósforos de alta intensidade utilizados na criação de bioimagens (upconversion) $^{[120]}$ e como traçadores ${ }^{[120,121]}$.

\subsection{Espectroscopia de absorção no infravermelho por transformada de Fourier (FTIR) e espectroscopia Raman}

Denomina-se como espectroscopia o método utilizado para análise de elementos simples, da estrutura química de compostos inorgânicos, ou de grupos funcionais de uma substância orgânica utilizando radiação eletromagnética. Sempre quando se excita uma substância com uma fonte de energia, esta pode tanto emitir como absorver radiação em determinado comprimento de onda, desta forma permitindo uma observação do comportamento da substância a ser analisada ${ }^{[122]}$. Os resultados das análises espectroscópicas de uma amostra resultam em dados sobre a estrutura do analito, tais como geometria de ligação, natureza química de ligantes de um dado átomo, comprimentos de ligações químicas e etc.

O fundamento da espectroscopia é a natureza ondulatória das radiações eletromagnéticas, cuja variável é a frequência fundamental determinando assim o número de oscilações realizadas pela onda por unidade de tempo e o comprimento de onda, a distância percorrida pela onda durante um período de tempo (unidade de frequência). $\mathrm{O}$ produto destas variáveis é definido como a velocidade de propagação da onda ${ }^{[123]}$.

A Espectroscopia de Absorção no Infravermelho por Transformada de Fourier (do inglês Fourier Transformed Infrared) é uma técnica que utiliza a região do infravermelho do espectro eletromagnético para caracterizar moléculas e biomoléculas. A chamada radiação infravermelha corresponde à parte do espectro eletromagnético situada entre as regiões do visível e das micro-ondas, pois é onde ocorrem vibrações e torções características de diversos grupos funcionais ${ }^{[124]}$. A porção mais comumente usada encontra-se entre 4000 e $400 \mathrm{~cm}^{-1[125]}$.

As ligações químicas das substâncias possuem frequências de vibração específicas, as quais correspondem a níveis vibracionais de energia. A radiação infravermelha provoca a vibração de átomos ou grupos de átomos e estas vibrações podem 
ter amplitudes e frequências diferentes e, portanto as energias das vibrações são quantizadas $^{[126]}$.

As vibrações moleculares podem ser classificadas em deformações axiais ou estiramento e deformações angulares. Uma vibração de deformação axial é um movimento ao longo do eixo da ligação que faz com que a distância interatômica aumente e diminua alternadamente. As vibrações de deformação angular correspondem a variações de ligações que têm um átomo em comum ou o movimento de um grupo de átomos em relação ao resto da molécula.

Somente as vibrações que levam à alteração do momento de dipolo da molécula são observadas no infravermelho ${ }^{[125]}$, pois a absorção de radiações eletromagnéticas por átomos ou moléculas exige que elas tenham energia apropriada, e que haja um mecanismo de interação que permita a transferência de energia. O mecanismo apropriado para a excitação vibracional é proporcionado pela variação periódica de dipolos elétricos na molécula durante as vibrações; a transferência de energia ocorre por interação destes dipolos oscilatórios com o campo elétrico oscilatório da luz, radiação infravermelha, desde que a frequência com que ambos variam seja a mesma ${ }^{[127]}$.

As moléculas diatômicas homonucleares, como $\mathrm{H}_{2}, \mathrm{~N}_{2}, \mathrm{O}_{2}, \mathrm{Cl}_{2}$ e etc., não têm dipolo elétrico, qualquer que seja a respectiva energia vibracional. Por isso, entre as moléculas diatômicas, só as heteronucleares como $\mathrm{HCl}, \mathrm{CO}$ e etc., têm espectros de absorção vibracional (espectro no infravermelho). No caso de moléculas poliatômicas sem dipolo elétrico, como por exemplo, $\mathrm{CO}_{2}$, há certas vibrações que produzem dipolos flutuantes; é o que se verifica com a flexão da molécula. Em regra, a excitação de vibrações de variação angular exige menor energia do que a de vibrações de estiramento $^{[128,129]}$.

O movimento dos átomos que constituem as moléculas resulta em rotações e vibrações moleculares. Consequentemente, além das transições entre níveis eletrônicos deve-se levar em consideração também as transições resultantes das rotações e vibrações. Todavia, como as energias envolvidas nas diferentes formas de rotação são muito semelhantes e a diferença entre dois níveis rotacionais é tipicamente algo em torno de $5 \times 10^{-5} \mathrm{eV}$, apenas as vibrações são geralmente consideradas. 
Basicamente, as vibrações moleculares podem ser classificadas em dois tipos: vibrações de deformação axial (stretching) e de deformação angular (bending). As deformações axiais ou estiramentos são oscilações radiais das distâncias entre os núcleos, enquanto que as deformações angulares envolvem variações dos ângulos entre as ligações ou, como no modo de deformação assimétrica fora do plano, alterações do ângulo entre o plano que contém as ligações e um plano de referência.

Quando as vibrações moleculares resultam em alterações de momento de dipolo, em consequência da variação da distribuição eletrônica ao redor das ligações, podese induzir transições entre os níveis vibracionais. Isto é feito com a aplicação de campos elétricos com frequências adequadas. Quando o dipolo oscilante se encontra em fase com o campo elétrico incidente, ocorre a transferência de energia da radiação para a molécula, resultando em uma transição. Portanto, para um grande número de moléculas, as energias associadas aos níveis vibracionais se encontram na região do infravermelho do espectro eletromagnético $^{[130]}$.

Assim como a espectroscopia de absorção (ou emissão) no infravermelho, a espectroscopia Raman fornece informações sobre níveis de energia vibracionais e sobre a estrutura molecular também. Como os processos físicos envolvidos em cada uma dessas duas técnicas são diferentes, com regras de seleção diferentes, as informações fornecidas por elas não são as mesmas, mas complementares ${ }^{[131]}$.

A espectroscopia Raman é uma técnica muito utilizada dentro da ciência dos polímeros, podendo prover informações, por exemplo, sobre a taticidade, a ordem/desordem molecular, o mecanismo de polimerização, a estrutura conformacional, transições de fase e, no caso de polímeros ou copolímeros coloridos é possível determinar a natureza de segmentos da cadeia polimérica ${ }^{[132]}$.

A espectroscopia Raman é uma técnica que se emprega nos estudos da física da matéria condensada, e em todo o âmbito de aplicações em química, bioquímica, farmacologia, ciências biológicas e da saúde. Apesar de a espectroscopia Raman basear-se em um processo de dispersão (scattering), ela faz parte da espectroscopia vibracional junto com a espectroscopia de absorção no infravermelho ${ }^{[122,123]}$. 
A utilização da espectroscopia Raman compreende também, além do estudo do espectro vibracional, o espectro rotacional e outros modos de baixas frequências em um sistema e tem base na dispersão inelástica, ou dispersão Raman da luz monocromática, usualmente proveniente de um laser no visível, infravermelho próximo ou situado na faixa espectral do ultravioleta próximo.

No efeito Raman a atividade está ligada ao momento de dipolo induzido na molécula pelo campo elétrico da radiação, que atua como um sistema perturbativo, e é diferente da espectroscopia no infravermelho onde consideramos o momento dipolar intrínseco ${ }^{[133,134]}$.

Existem três mecanismos básicos de dispersão dos fótons quando incidem em uma molécula: espalhamento Stokes, espalhamento anti Stokes e espalhamento Rayleigh, FIG.3.6. Os dois primeiros processos de dispersão são espalhamentos inelásticos da radiação monocromática que incide em uma molécula, no entanto, o espalhamento Rayleigh é do tipo elástico. Nos dois primeiros casos, a molécula pode passar de um estado vibracional para outro e diferenciam-se nas grandezas de frequência $v_{0}-v_{\mathrm{v}}$ e $v_{0}+v_{\mathrm{v}}$, que correspondem aos espalhamentos Raman Stokes e Raman anti Stokes, respectivamente.

Esses espalhamentos citados podem ser visualizados na FIG. 3.6 e 3.7.

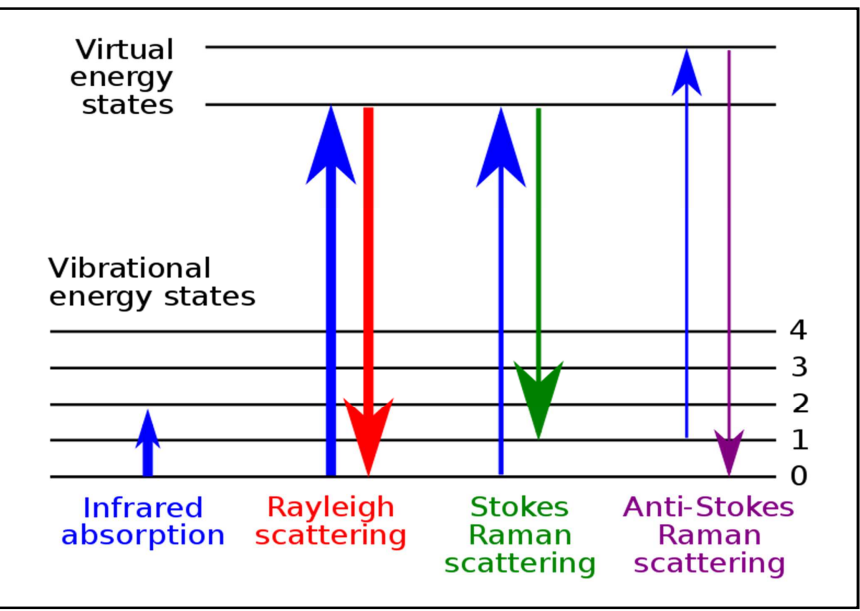

FIGURA 3.6. Caminho dos elétrons (Raman) ${ }^{[135]}$. 


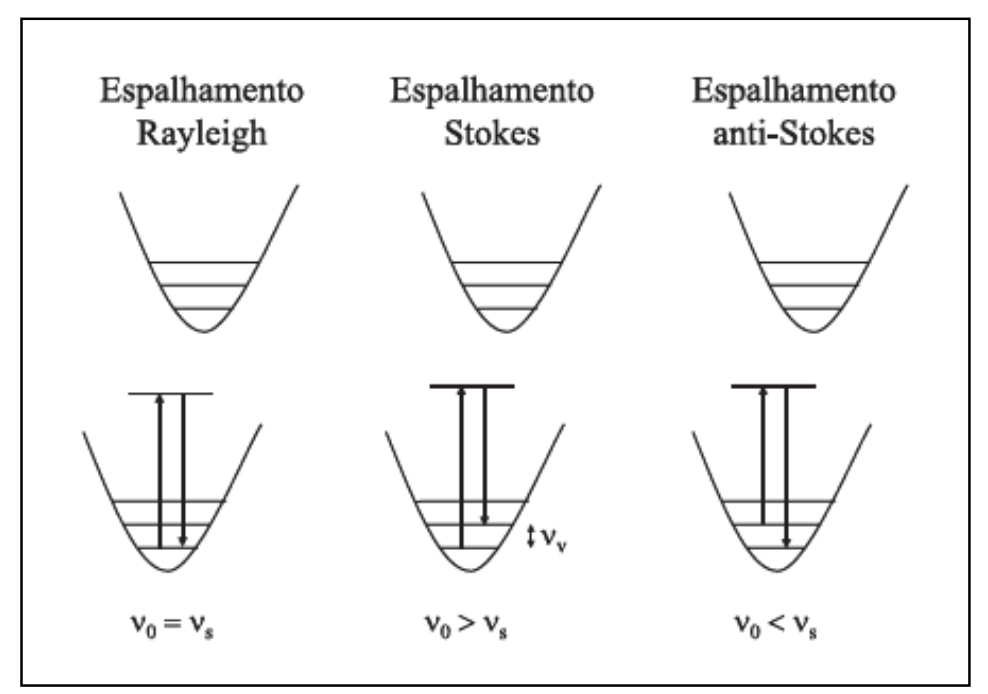

FIGURA 3.7. Esquema do mecanismo de espalhamento elástico (Rayleigh) e inelástico (Stokes e anti-Stokes). $v_{0}, v_{\mathrm{S}}$ e $v_{\mathrm{v}}$ são as frequências, proporcionais às energias, da radiação excitante, da radiação espalhada e da transição vibracional, respectivamente ${ }^{[135]}$.

As técnicas de FTIR e Raman foram empregadas neste trabalho como ferramentas de comparação entre os resultados obtidos pelos ensaios biológicos qualitativos para futuros estudos de validação da metodologia de triagem diagnóstica desenvolvida. 


\section{REFERÊNCIAS BIBLIOGRÁFICAS}

[1] VERRASTRO, T.; LORENZI, T.F.; NETO, S.W. Hematologia e Hemoterapia Fundamentos de morfologia, fisiologia, patologia e clínica. São Paulo: Atheneu, 2002.

[2] PIERIGÈ, F.; SERAFINI, S.; ROSSI, L.; MAGNANI, M. Cell-based drug delivery. Adv. Drug Deliv. Rev., v. 60, n. 2, p. 286-295, 2008.

[3] SCHMIDT, R.D. Laboratory diagnosis of hemoglobinopathies. Jama, v. 224, p. 1276-1280, 1973.

[4] NAOUM, P.C. Hemoglobinopatias e talassemias. São Paulo: Sarvier, 1997.

[5] SOMMER, C.K.; GOLDBECK, A.S.; WAGNER, S.C.; CASTRO, S.M. Triagem neonatal para hemoglobinopatias: experiência de um ano na rede de saúde pública do Rio Grande do Sul, Brasil. Cad. Saúde Pública, v. 22, p. 1709-1714, 2006.

[6] HERRICK, J.B. Peculiar elongated and sickle-shaped red blood corpuscles in a case of severe anemia. Arch. Intern. Med., v. 6, n. 5, p. 517-521, 1910.

[7] WHO Working Group. Hereditary anemias: genetics basis, clinical features, diagnosis and treatment, WHO, v. 60, p. 643-660, 1982.

[8] STUART, M. J.; NAGEL, R. L. Sickle-cell disease. Lancet, v. 364, p. 1343-1360, 2004.

[9] BANDEIRA, F.M.G.C.; LEAL, M.C.; SOUZA, R.R.; FURTADO, V.C.; GOMES, Y.M.; MARQUES, N.M. Características de recém-nascidos portadores de hemoglobina S detectados através de triagem em sangue de cordão umbilical. J. Pediatr., v. 75, n. 3, p. 167-171, 1999.

[10] CRUSIUS, Y.R. Política Estadual de Atenção Integral às Pessoas com Doença Falciforme e outras Hemoglobinopatias. Disponível em: <http://www.saude.rs.gov.br/upload/1337785202_PoliticaFalciforme.pdf> Acesso em: 24 jun. 2014.

[11] PES 20092011 FINAL, Disponível em: <http://www.saude.rs.gov.br/upload/1338584896MODIFICADO $\quad$ EM $22 \quad 09$ 10.pdf> Acessado em: 01 ago 2014. 
[12] COMPRI, M.B.; POLIMENO, N.C.; STELLA, M.B.; RAMALHO, A.S. Programa comunitário de hemoglobinopatias hereditárias em população estudantil brasileira. Rev. Saúde Pública, v. 30, n. 2, p. 187-195, 1996.

[13] CANÇADO, R.D.; JESUS, J.A. A doença falciforme no Brasil. Rev. Bras. Hematol Hemoter., v. 29, n. 3, p. 204-206, 2007.

[14] Programa de Atenção às Pessoas com Doença Falciforme. Manual do Agente de Saúde. Grupo de Trabalho de saúde da População Negra -GTSPN/SMS/SEMUR. Salvador, 2005.

[15] DiAllo, D.; TCHERniA, G. Sickle cell disease in Africa. Curr. Opin. Hematol., v. 9, p. 111-116, 2002.

[16] WRIGHT, K.; ADEOSUM, O. Barriers to effective pain management in sickle cell disease. Br. J. Nurs., v. 18, p. 158-161, 2009.

[17] KRAL, M.C.; BROWN, R.T.; HYND, G.W. Neuropsychological aspects of pediatric sickle cell disease. Neuropsychol Rev., v. 11, n. 4, p. 179-196, 2001.

[18] EJINDU, V.C.; HINE, A.L.; MASHAYEKHI, M.; SHORVON, P.J.; MISRA, R.R. Musculoskeletal manifestations of sickle cell disease. Radiographics, v. 27, n. 4, p. $1005-$ 1021, 2007.

[19] ARDILES, T.; DARK, D. Pulmonary complications of sickle cell disease in adults. Mo. Med., v. 104, n. 3, p. 250-254, 2007.

[20] FRENETTE, P.S.; ATWEH, G.F. Sickle cell disease: old discoveries, new concepts, and future promise. J. Clin. Invest., v. 117, n. 4, p.850-858, 2007.

[21] WILLIAM, B.M., CORAZZA, G.R. Hyposplenism: a comprehensive review. Part I: basic concepts and causes. Hematology, v. 12, n.1, p. 1-13, 2007.

[22] KHATTAB, A.D.; RAWLINGS, B.; ALI, I.S. Care of patients with haemoglobin abnormalities: history and biology. Br. J. Nurs., v. 15, n. 8, p. 994-998, 2006.

[23] MAZUMDAR, M.; HEENEY, M.M.; SOX, C.M.; LIEU, T.A. Preventing Stroke Among Children With Sickle Cell Anemia: An Analysis of Strategies That Involve Transcranial Doppler Testing and Chronic Transfusion. Pediatrics, v. 120, n. 4, p. e1107e1116, 2007. 
[24] ADAMS, R.J.; MCKIE, V.C.; HSU, L.; FILES, B.; VICHINSKY, E.; PEGELOW, C.; ABBOUD, M.; GAllaGHER, D.; KUTLAR, A.; NICHOLS, F.T.; BONDS, D.R.; BRAMBILLA, A.D. Prevention of a first stroke by transfusions in children with sickle cell anemia and abnormal results on transcranial Doppler ultrasonography. N. Engl. J. Med., v. 339, n. 1, p. 5-11, 1998.

[25] ADAMS, R.J. Lessons from the Stroke Prevention Trial in Sickle Cell Anemia (STOP) study. J. Child Neurol., v. 15, n. 5, p. 344-349, 2000.

[26] NOLAN, V.G.; ADEWOYE, A.; BALDWIN, C.; WANG, L.; MA, Q.; WYSZYNSKI, D.F.; FARRELL, J.J.; SEBASTIANI, P.; FARRER, L.A.; STEINBERG, M.H. Sickle cell leg ulcers: associations with haemolysis and SNPs in Klotho, TEK and genes of the TGFbeta/ BMP pathway. Br. J. Haematol., v. 133, n. 5, p. 570-578, 2006.

[27] XU, K.; SHI, Z.M.; VEECK, L.L.; HUGHES, M.R.; ROSENWAKS, Z. First unaffected pregnancy using preimplantation genetic diagnosis for sickle cell anemia. JAMA, v. 281, n. 18, p. 1701-1706, 1999.

[28] SILVA, R.B.P.; RAMALHO, A.S. Riscos e benefícios da triagem genética: o traço falciforme como modelo de estudo em uma população brasileira. Cad. Saúde Pública, v. 13, p. 285-94, 1997.

[29] EMBURY, S.H. Anemia falciforme e hemoglobinopatias associadas. In: Bennett JC, Plum F. Cecil tratado de medicina interna. Rio de Janeiro: Guanabara Koogan, 1997. p. 976-988.

[30] ALVES, A.L. Estudo da mortalidade por anemia falciforme. Inf. Epidemiol. SUS., v. 5, p. 45-53, 1996.

[31] TOMÉ-ALVES, R.; MARCHI-SALVADOR, D.P.; ORLANDO, G.M.; PALHARINI, L.A.; IMPERIAL, R.E.; NAOUM, P.C., BONINI-DOMINGOS, C.R. Hemoglobinas AS/Alfa talassemia - importância diagnóstica. Rev. Bras. Hematol. Hemoter., v. 22, n. 3, p. 388-394, 2000.

[32] MURÃO, M.; FERRAZ, M.H.C. Traço falciforme, heterozigose para hemoglobina S. Rev. Bras. Hematol. Hemoter., v. 29, p 223-225, 2007.

[33] RAMALHO, A.S.; MAGNA, L.A. Aconselhamento genético do paciente com doença falciforme. Rev. Bras. Hematol. Hemoter., v. 29, p. 229-232, 2007. 
[34] NAOUM, P.C. Prevalência e controle da hemoglobina S. Rev. Bras. Hematol. Hemoter., v. 22, p. 144-148, 2000.

[35] RAMALHO, A.S. Hemoglobina S em doadores de sangue brasileiros. Rev. Ass. Med. Bras., v. 22, p. 467-468, 1976.

[36] MELlO, S.M.A.; ARANTES, S.C.F.; BOTELHO FILHO, A.; ROCHA, A.F.S. Prevalência de hemoglobinopatias em doadores de sangue do Hemocentro Regional de Uberlândia-MG. Bol. Soc. Bras. Hematol. Hemoter., v. 20, p. 130, 2000.

[37] ORLANDO, G.M.; NAOUM, P.C.; SIQUEIRA, F.A.M.; BONINI-DOMINGOS, C.R. Diagnóstico laboratorial de hemoglobinopatias em populações diferenciadas. Rev. Bras. Hematol. Hemoter., v. 22, p. 111-121, 2000.

[38] ACEDO, M.J.; COSTA, V.A.; POLIMENO, N.C.; BERTUZZO, C.S. Programa comunitário de hemoglobinopatias: abordagem populacional a partir de doadores de sangue de Bragança Paulista, São Paulo, Brasil. Cad. Saúde Pública, v. 18, p. 1799-1802, 2002 .

[39] GRIGNANI, C.; AMARAL, C.L.; IAMAMOTO, C.A.; GONÇALVES, T.O.; MASHIMA, D.A.; MATSUO, T.; PERIM, A.L.; CARVALHO, S.R.Q.; BREGANÓ, J.W.; FAVERO, M.E. Prevalência de traço falciforme em doadores de sangue da região de Londrina-Paraná. Rev. Bras. Anal. Clin., v. 38, p. 259-262, 2006.

[40] LISOT, C.L.A.; SILLA, L.M.R. Triagem de hemoglobinopatias em doadores de sangue de Caxias do Sul, RS, Brasil: prevalência em área de colonização italiana. Cad. Saúde Pública, v. 20, p. 1595-1601, 2004.

[41] PRUDENCIO, B.C.A.B.; COVAS, D.T.; BONINI-DOMINGOS, C.R. Comparação de metodologia utilizada para a detecção de Hemoglobina $\mathrm{S}(\mathrm{HbS})$ em doadores de sangue. Rev. Bras. Hematol. Hemoter., v. 22, p. 99-109, 2000.

[42] MELLO, S.M.A.; ARANTES, S.C.F.; BOTELHO FILHO, A.; ROCHA, A.F.S. Prevalência de hemoglobinopatias em doadores de sangue do Hemocentro Regional de Uberlândia-MG. Bol. Soc. Bras. Hematol. Hemoter., v. 20, p. 130, 2000.

[43] ITANO, H.A. Solubilities of naturally occurring mixtures of human hemoglobin. Arch. Biochem. Biophys., v. 47, p.148-159, 1953. 
[44] ADACHI, K.; ASAKURA, T. Demonstration of a delay time during aggregation of diluted solutions of deoxyhemoglobin $\mathrm{S}$ and hemoglobin Charlem in concentrated phosphate buffer. J. Biol. Chem., v. 253, p. 6641-6643, 1978.

[45] ADACHI, K.; ASAKURA, T. Nucleation-controlled aggregation of deoxyhemoglobin-S possible difference in the size of nuclei in different phosphate concentrations. J. Biol. Chem., v. 25, p. 7765-7771, 1979.

[46] ADACHI, K.; ASAKURA, T. Multiple nature of polymers of deoxyhemoglobin-S prepared by different methods. J. Biol. Chem., v. 258, p. 3045-3050, 1983.

[47] WANG, Z.; KISHCHENKO, G.; CHEN, Y.; JOSEPHS, R. Polymerization of deoxy-sickle cell hemoglobin in high-phosphate buffer. J. Struct. Biol., v. 131, p. 197-209, 2000.

[48] CLARKE, G.M.; HIGGINS, T.N. Laboratory investigation of hemoglobinopathies and thalassemias: review and update. Clin. Chem., v. 46, p. 1284-1290, 2000.

[49] RODRIGUEZ-DIAZ, R.; WEHR, T.; ZHU, M. Capillary isoelectric focusing. Electrophoresis, v. 18, p. 2134-2144, 1997.

[50] JENKINS, M.A.; RATNAIKE, S. Capillary isoelectric focusing of haemoglobin variants in the clinical laboratory. Clin. Chim. Acta, v. 289, p. 121-132, 1999.

[51] HEAD, C.E.; CONROY, M.; JARVIS, M.; PHELAN, L.; BAIN, B.J. Some observations on the measurent of haemoglobin $\mathrm{A}_{2}$ and $\mathrm{S}$ percentages by high performance liquid chromatography in the presence and absence of thalassaemia. J. Clin. Pathol., v. 57, p. 276-280, 2004.

[52] WEATHERALL, D.J.; CLEGG, J.B. Inherited haemoglobin disorders: an increasing global health problem. Bull. World Health Organ., v. 79, p. 704-712, 2001.

[53] MATUSIK, J.E.; POWELL, J.B.; GREGORY, D.M. Rapid solubility test for detection of hemoglobin. Clin. Chem., v. 17, p. 1081-1082, 1971.

[54] SCHMIDT, R.M.; WILSON, S.M. Standardization in detection of abnormal hemoglobins. J. Am. Med. Assoc., v. 225, p. 1225-1230, 1973.

[55] YANG, X.; KANTER, J.; PIETY, N.Z.; BENTON, M.S.; VIGNES, S.M.; SHEVKOPLYAS, S.S. A simple, rapid, low-cost diagnostic test for sickle cell. Lab. Chip., v. 13, p. 1464-1467, 2013. 
[56] YANG, X.; FOROUZAN, O.; BROWN, T.P.;SHEVKOPLYAS, S.S. Integrated separation of blood plasma from whole blood for microfluidic paper-based analytical devices. Lab. Chip., v. 12, p. 274-280, 2012.

[57] Brasil. Ministério da Saúde. Gabinte do Ministro. Portaria no 153 de 14 de junho de 2004. Aprova as normas técnicas para coleta, processamento e transfusão de sangue, componentes e derivados e dá outras providências. Brasília (DF), 2004.

[58] NAOUM, P.C. Hemoglobinopatias e talassemias. São Paulo: Sarvier, 1997.

[59] OSHIRO, M.; POLI NETO, A.; MIGHITA, K.; WATANABE, C.I.; PALHARINI, D.L.B. Estudo comparativo entre os testes de solubilidade, falcização e gel-centrifugação para a detecção populacional da hemoglobina S. Rev. Inst. Adolfo Lutz, v. 58, p. 53-56, 1999.

[60] ElghetANY, M.T.; DAVEY, F.R. Doenças eritrocitárias. In: Henry, J.B. Diagnósticos clínicos e tratamento por métodos laboratoriais. São Paulo: Manole, 1999. p. 617-663.

[61] BALLARD, M.S.; RADEL, E.; SAKHADEO, S.; SCHORR, J.B. A new diagnostic test for hemoglobin S. J. Pediat., v. 76, p. 117-119, 1970.

[62] MATUSIK, J.E.; POWELL, J.B.; GREGORY, D.M. Rapid solubility test for detection of hemoglobin S. Clin. Chem., v. 17, n. 11, p. 1081-1082, 1971.

[63] CLARK, K.G.A. An improved solubility test for haemoglobin S. J. Clin. Pathol., v. 25, n. 8 , p. $730-731,1972$.

[64] DEL GUIDICE, R.E.; DOARING, R.M.; TERAN, A. Evaluation of sicklequick a differential solubility test for hemoglobin S. Am. J. Med. Technol., v. 45, n. 4, p. 287-289, 1979.

[65] SURVE, R.R.; MURKHERJEE, M.B.; KATE, S.L.; NAGTILAK, S.B.; WADIA, M.; TAMANKAR, A.A. Deteccion of the $\mathrm{S}$ gene: an evaluation of the solubility test against automated chromatography and haemoglobin electrophoresis. Br. J. Biomed. Sci., v. 57, p. 292-294, 2000.

[66] BALASUBRAMANIAM, J.; PHELAN, L.; BAIN, B.J. Evaluation of a new screening test for sickle cell haemoglobin. Clin Lab Haem., v. 23, p. 379-383, 2001. 
[67] DEGANI, A.L.; CASE, Q.L.; VIERA, P.C. Cromatografia um breve ensaio. Quím. Nova na Escola, n. 7, p. 21-25, 1998.

[68] ETTRE, L.S. Chromatography: the separation technique of the $20^{\text {th }}$ century. Chromatographia, v. 51, n. 1/2, p. 7-17, 2000.

[69] PERES, T.B. Noções básicas de cromatografia. Biológico. Biológico, v. 64, n. 2, p. 227-229, 2002.

[70] ADAMOWICZ, P.; KALA, M. Simultaneous screening for and determination of 128 date-rape drugs in urine by gas chromatography-electron ionization-mass spectrometry. Forensic. Sci. Intern., v. 198, p. 39-45, 2010.

[71] VAN DEN BERG, A.; LAMMERINK, T. S. J. Micro total analysis systems: Microfluidic aspects, integration concept and applications. Top. Curr. Chem., v. 194, p. 21-49, 1998.

[72] VILKNER, T.; JANASEK, D.; MANZ, A. Micro total analysis systems. Recent developments. Anal. Chem., v. 76, p. 3373-3386, 2004.

[73] CHEN, Y.; PÉPIN, A. Nanofabrication: Conventional and nonconventional methods. Electrophoresis, v. 22, p. 187-207, 2001

[74] MADOU, M.J. Fundamentals of Microfabrication, 2 ed. CRC Press: New York, 2002.

[75] WOOLEY, A.T.; LAO, K.; GLAZER, A.N.; MATHIES, R.A. Capillary electrophoresis chips with integrated electrochemical detection. Anal. Chem., v. 70, p. 684-688, 1998.

[76] BILITEWSKI, U.; GENRICH, M.; KADOW, S.; MERSAL, G. Biochemical analysis with microfluidic systems. Anal. Bioanal. Chem., v. 377, p. 556-569, 2003.

[77] AUROUX, P.A.; IOSSIFIDIS, D.; REYES, D.R.; MANZ, A. Micro total analysis systems. 2. Analytical standard operations and applications. Anal.Chem., v. 74, p. 2637 2652, 2002.

[78] VILKNER, T.; JANASEK, D.; MANZ, A. Environmental mass spectrometry: Emerging contaminants and current issues. Anal. Chem., v. 76, p. 3373-3364, 2004.

[79] DITTRICH, P.S.; TACHIKAWA, K.; MANZ, A. Micro total analysis systems. Latest advancements and trens. Anal. Chem., v. 78, p. 3887-3908, 2006. 
[80] WOOLEY. A.T.; LAO, K.; GLAZER, A.N.; MATHIES, R.A. Capillary electrophoresis chips with integrated electrochemical detection. Anal. Chem., v. 70, p. 684-688, 1998.

[81] TERRY, S.C.; JERMAN, J.H.; ANGELL, J.B. A gas chromatographic air analyzer fabricated on a silicon wafer. IEEE Trans. Electron Devices, v. ED-26, p. 1880-1886, 1979.

[82] REYES, D.R.; IOSSIFIDIS, D.; AUROUX, P.A.; MANZ, A. Micro total analysis system. 1. Introduction, theory, and technology. Anal. Chem., v. 74, p. 2623-2636, 2002.

[83] MANZ, A.; MIYAHARA, Y.; MIURA, J.; WATANABE, Y.; MIYAGI, H.; SATO, K. Design of an open-tubular column liquid chromatograph using silicon chip technology. Sens. Actuators B, v. 1, p. 249-255, 1990.

[84] MANZ, A.; GRABER, N.; WIDMER, H. M. Minaturized total chemical analysis systems: A novel concept for chemical sensing. Sens. Actuators B, v. 1, p. 244-248, 1990.

[85] FROST \& SULLIVAN Lab-on-a-chip: The Revolution in portable instrumentation, 3 ed. New York, 1999. p. 17. Disponível em: < http://www.frost.com/sublib/displayreport.do?searchQuery=Lab-on-a-chip\%3A+The+Revolution+in+portable+instrument>, Acesso em: 07 out. 2014.

[86] GULliKSEN, A.; SOlli, L.; KARLSEN, F.; ROGNE, H.; HOVIG, E.; NORDSTROM, T.; SIREVÁG, R. Real-time nuclei acid sequence-based amplification in nanoliter volumes. Anal. Chem., v. 76, p. 9-14, 2004.

[87] YANG, X.; KANTER, J.; PIETY, N.Z.; BENTON, M.S.; VIGNES, S.M.; SHEVKOPLYAS, S.S. A simple, rapid, low-cost diagnostic test for sickle cell. Lab. Chip., v. 13, p. 1464-1467, 2013.

[88] CARRILHO, E.; MARTINEZ, A.W.; WHITESIDES, G.M. Understanding Wax Printing: A Simple Micropatterning Process for Paper-Based Microfluidics. Anal. Chem., v. 81, p. 7091-7095, 2009.

[89] SABBATINI, N.; GUARDIGLI, M.; MANET, I; UNGARO, R.; CASNATI, A.; ZIESSEL, R.; ULRICH, G.; ASFARI, Z.; LEHN, J. M. Lanthanide complexes of encapsulating ligands: luminescent devices at the molecular level. Pure and Appl. Chem., v. 67, p. 135-140, 1995.

[90] ABRÃO, A. Química e tecnologia das terras raras. Rio de Janeiro: Cetem, 1994. 
[91] FORSBERG, J. H. Complexes of lanthanide(III) ions with hidrogen donor ligands. Coord. Chem. Rev., v. 10, p. 195-226, 1973.

[92] BLASSE, G.; BRIL, A. Characteristic luminescence. Philips Techn. Rev., v. 31, p. 303-331, 1970.

[93] BÜNZLI, J. C. G.; CHOPPIN, G. R. Lanthanide probes in life, chemical and earth science. Amsterdan: Elsevier, 1989.

[94] DAVOLOS, M. R. Complexos de manganês(II) e fosfinóxidos: absorção e luminescência. 1983. Tese (doutorado) - Instituto de Química, Universidade de São Paulo, São Paulo.

[95] MATOS, J. R. Estudo comparativo dos compostos de adição entre metanossulfonatos de lantanídeos(III) e aminóxidos aromáticos como ligantes. 1989. Tese (doutorado) - Instituto de Química, Universidade de São Paulo, São Paulo.

[96] BECKER, R. S. Theory and interpretation of fluorescence and phosphorescence. New York: Wiley Interscience, 1969.

[97] GUILBALT, G. G. Practical fluorescence. New York: Marcel Dekker, 1973.

[98] SIMONS, J. P. Photochemistry and spectroscopy. London: Wiley Interscience, 1971.

[99] DEMAS, J. N. Photophysical pathways in metal complexes. J. Chem., v. 60, p. 803-808, 1983.

[100] MOELLER, T. The chemistry of the lanthanides. New York: Reinhold Publishing Corporation, 1963.

[101] SINHA, S. P. Complexes of rare earths. New York: Pergamon Press, 1966.

[102] CARNALL, W. T.; GOODMAN, G. L.; RAJANK, K.; RANA, R .S. A systematic analysis of the spectra of the lanthanides doped into single crystal LaF 3 solution. Chicago: Argonne National Laboratory Report, 1988.

[103] WEISSMAN, S. I. Intramolecular energy transfer the fluorescence of complexes of europium. J. of Chem. Phys., v. 10, p. 214-217, 1942.

[104] DE LA TORRE, M.A.C.; GOMEZ-HENS, A. Evaluation of the terbium(III)sensitized luminescence with benzenepolycarboxylic acids: Determination of terephthalic acid in drink samples. Anal. Chim. Acta, v. 407, p. 53-60, 2000. 
[105] LIMA. P.P.; MALTA, O.L.; ALVES JÚNIOR, S. Estudo espectroscópico de complexos de $\mathrm{Eu}^{3+}, \mathrm{Tb}^{3+}$ e $\mathrm{Gd}^{3+}$ com ligantes derivados de ácidos dicarboxílicos. Quím. Nova, v. 28, n. 5, p. 805-805, 2005.

[106] TOBITA, S.; ARAKAWA, M.; TANAKA, I. The paramagnetic metal effects on the ligand localized S1-T1 intersystem crossing in the rare earth metal complexeswith mehtyl salycilate. J. of Phys. Chem., v. 89, p. 5649-5654, 1985.

[107] CROSBY, G. A.; ALIRE, R. M.; WHAN, R. E. Intramolecular energy transfer in rare earth chelates: role of triplet state. J. Phys. Chem., v. 34, p. 743-748, 1961.

[108] WHAN, R. E.; CROSBY, G. A. Luminescence studies of rare earth complexes: benzoylacetonate dibenzoylmethide chelates. J. of Mol. Spectroscopy., v. 8, n. 4, p. 315$327,1962$.

[109] KLEINERM, M. Energy migration in lanthanide chelates. J. of Chem. Phys., v. 51, p. 2370-2381, 1969.

[110] BHAUMIK, M. L.; ELSAYED, M. A. Mechanism and rate of intramolecular energy transfer process in rare earth chelates. J. of Chem. Phys., v. 42, p. 787-788, 1965.

[111] BUONOCORE, G. E.; LI, H.; MARCINIAK, B. Quenching of excited states by lanthanide ion and chelates in solutions. Coord. Chem. Rev., v. 99, p. 55-87, 1990.

[112] SABBATINI, N.; GUARDIGLI, M.; LENH, J.M. Luminescente lanthanide complexes as photochemical supramolecular devices. Coord. Chem. Rev., v.123, n.1-2 p.201-228, 1993.

[113] TEOTONIO, E.E.S. Síntese e investigação das propriedades fotoluminescentes de dispositivos moleculares conversores de luz (DMCL) de complexos dicetonatos de terras raras com ligantes amidas. 2004. Tese (doutorado) - Instituto de Química, Universidade de São Paulo, São Paulo.

[114] HALL, E. A. H. Biosensors. Buckingham: Open University Press, 1990. p. 3-29.

[115] KAROL, P. J. Label. in: Glossary of terms for radiochemistry and nuclear techniques, 2001. Disponível em: <http://www.iupac.org/V7_karol/Main.html>, Acesso em: 07 out. 2014.

[116] KAROL, P. J. Tracer. In Glossary of terms for radiochemistry and nuclear techniques Disponível em: <http://www.iupac.org/V7_karol/Main.html>, Acesso em: 07 out. 2014. 
[117] HAUGLAND, R. P. Ultrasensitive detection technology. In Handbook of fluorescent probes and research chemicals. 8 ed. Eugene: Molecular Probes, 2001.

[118] HEMMILÄ, I.; HARJU, R.; Time-resolved fluorometry. In: Bioanalytical Applications of Labelling Technologies. Turku: EG\&G Wallac, 1994. p.83-119.

[119] ENGBIOTEC. Catalisadores a base de terras raras. Disponível em: <http://engbiotec.wordpress.com/tag/hidrocarbonetos/>, Acesso em: 12 jan. 2014.

[120] WANG, S.; FENG, J.; SONG, S.; ZHANG, H. Rare earth fluorides upconversion nanophosphors: from synthesis to applications in bioimaging. Cryst. Eng. Comm., v. 15, n. 36, p. 7142-7151, 2013.

[121] LOURENÇO, A.V.S.; KODAIRA, C.A.; RAMOS-SANCHEZ, E.M.; FELINTO, M.C.F.C.; GOTO, H.; GIDLUND, M.; MALTA, O.L.; BRITO, H.F. Luminescent material based on the $\left[\mathrm{Eu}(\mathrm{TTA})_{3}\left(\mathrm{H}_{2} \mathrm{O}\right)_{2}\right]$ complex incorporated into modified silica particles for biological applications. J. Inorg.Chem., v. 123, p. 11-17, 2013

[122] SANTOS, P.S.; SALA, O.; BASSI, D.; HASE, Y., FORNERIS, R.; TEMPERINI, M.L.A.; KAWANO, Y. Espectroscopia Molecular Princípios e Aplicações. São José dos Campos: EDUSP, 1984.

[123] SALA, O. Fundamentos da espectroscopia Raman e no infravermelho. São Paulo: Editora da Universidade Estadual Paulista Ciência e Tecnologia. 1996.

[124] PAVIA, D.L.; LAMPMAN, G.M.; KRIZ, G.S.; VYVYAN, J.A. Introduction to Spectroscopy. Filadelfia: Brooks/Cole Pub Co, 2000. p. 3-12.

[125] SILVERSTEIN, R.M.; KIEMLE, D.J.; WEBSTER, F.X. Identificação Espectrométrica de Compostos Orgânicos. 6 ed. Rio de Janeiro: LTC, 2000. p. 60-74.

[126] COLTHUP, N.B.; DALY, L.H.; WIBERLEY, S.H. Introduction to Infrared and Raman Spectroscopy, New York and London: Academic Press, 1964. p. 275.

[127] HOLLAS, J. M. Modern Spectroscopy. 4 ed. New York: John Wiley \& Sons, 1987.

[128] ATHINKS, P. W. Molecular Quantum Mechanics. New York: Oxford University Press, 1989.

[129] HERZBERG, G. Molecular spectra and molecular structure. I. Spectra of diatomic molecules. New York: D. Van Nostrand, 1951.

[130] LEVINE, I. N. Molecular Spectroscopy. England: John Wiley \& Sons, 1975. 
[131] FARIA, D.L.A.; SANTOS, L.G.C.; GONÇALVES, N.S. Uma demonstração sobre o espalhamento inelástico de luz: repetindo o experimento de Raman. Quim. Nova, v. 20, p. 319-323, 1997.

[132] ZERBI, G., DEL ZOPPO, M. Modern Polymer Spectroscopy. New York: WilleyVCH, 1999. cap. 3.

[133] PORTO, S.P.S.; WOOD, D.L. Ruby optical maser as a Raman source. J. Opt. Soc. Am., v. 52, p. 251-252, 1962.

[134] NAKAMOTO, K. Infrared and Raman Spectra of Inorganic and Coordination Compounds. New York: John Wiley \& Sons, 1986.

[135] TOSATO, M.G. Análise dos constituintes da pele humana sob efeitos de cosmecêuticos por espectroscopia Raman. 2010. Dissertação de mestrado - Instituto de pesquisa e desenvolvimento da Universidade do Vale do Paraíba, São José dos Campos. 
4

Parte Experimental 


\section{$4 \quad$ Parte Experimental}

Este trabalho foi dividido em três partes principais: A síntese do marcador de európio [Eu(TTA $\left.)_{3}(4-\text { picNO })_{2}\right]$ e sua caracterização, o desenvolvimento de uma metodologia por point-of-care para detecção de anemia falciforme e a inclusão de um marcador luminescente, $\left[\mathrm{Eu}(\mathrm{TTA})_{3}\right.$.2(4-picNO)] para aumentar a eficiência do método point-of-care e por último a utilização da espectroscopia de infravermelho e Raman como um método comparativo. Vale salientar que este projeto é aprovado pelo comitê de ética para seres humanos do instituto de ciências biomédicas da USP - ICB IV, para retirada de amostras de sangue total do hospital universitário HU/USP, sob o número CAAE 11149212.1.0000.5467.

\subsection{Materiais}

\subsubsection{Reagentes}

Os reagentes utilizados neste trabalho foram empregados sem tratamento prévio, com exceção dos solventes, álcool etílico e acetona que foram tratados de acordo com o procedimento descrito nas referências ${ }^{[1,2]}$. Na TAB. 4.1 encontra-se a relação dos reagentes usados e suas procedências.

TABELA 4.1. Relação das substâncias usadas e suas procedências.

\begin{tabular}{|l|l|}
\hline \multicolumn{1}{|c|}{ Substâncias } & Marca \\
\hline Hidrossulfito de sódio, $85 \%, \mathrm{Na}_{2} \mathrm{~S}_{2} \mathrm{O}_{4}$ & Sigma \\
\hline Tiossulfato de sódio, $\mathrm{Na}_{2} \mathrm{~S}_{2} \mathrm{O}_{3}$ & Merck \\
\hline Peróxido de hidrogênio, $35 \%, \mathrm{H}_{2} \mathrm{O}_{2}$ & Synth \\
\hline Ácido cítrico, $65 \%, \mathrm{C}_{2} \mathrm{H}_{4} \mathrm{O}_{2}$ & Merck \\
\hline
\end{tabular}




\begin{tabular}{|c|c|}
\hline 2-cloroacetamida, $\mathrm{C}_{2} \mathrm{H}_{4} \mathrm{CINO}$ & Merck \\
\hline Saponina, $\sim 25 \%, \mathrm{C}_{43} \mathrm{H}_{70} \mathrm{O}_{13}$ & Sigma \\
\hline $\begin{array}{l}\text { Surfactante Comercial, Alquil Benzeno Sulfonato de } \\
\text { Sódio Linear, Limpol® }\end{array}$ & Bombril \\
\hline $\begin{array}{l}\text { Tween 20, Monooleato de Sorbitan Etoxilado, } \\
\mathrm{C}_{64} \mathrm{H}_{124} \mathrm{O}_{26}\end{array}$ & Hiper Química \\
\hline Fosfato de potássio monobásico anidro P.A, $\mathrm{KH}_{2} \mathrm{PO}_{4}$ & Synth \\
\hline Fosfato de potássio bibásico Anidro P.A, $\mathrm{Na}_{2} \mathrm{HPO}_{4}$ & Neon \\
\hline L-ácido glutâmico, $\left(\mathrm{C}_{5} \mathrm{H}_{9} \mathrm{NO}_{4}\right)$ & Ajinomoto/Butantã \\
\hline $\begin{array}{l}\text { L-valina; Ácido 2-aminovalérico ou Ácido 2-amino-3- } \\
\text { metil-butanóico }\left(\mathrm{C}_{5} \mathrm{H}_{11} \mathrm{O}_{2} \mathrm{~N}\right)\end{array}$ & Ajinomoto/Butantã \\
\hline 2 - tenoil trifluoroacetona & Aldrich \\
\hline Cloreto de európio hexahidratado & China \\
\hline 4-picolina-N-Óxido & Aldrich \\
\hline Acetona, $91 \%, \mathrm{C}_{3} \mathrm{H}_{6} \mathrm{O}$ & Merck \\
\hline Alcool Etílico, $96 \%, \mathrm{C}_{2} \mathrm{H}_{6} \mathrm{O}$ & Merck \\
\hline Hidróxido de Sódio, 99\%, $\mathrm{NaOH}$, & Synth \\
\hline Água ultra pura, CQMA. & MiliQ \\
\hline $\begin{array}{l}\text { Hemoglobina AA, hemoglobina A1: } 97,1 \% \text {; } \\
\text { hemoglobina A2: } 2,3 \% \text {; hemoglobina fetal } 0,6 \% \text {. } \\
\text { Avaliação das hemoglobinas: método realizado por } \\
\text { cromatografia líquida de alta performance (HPLC). }\end{array}$ & PNCQ \\
\hline $\begin{array}{l}\text { Hemoglobina AS, hemoglobina A1: } 62,0 \% \text {; } \\
\text { hemoglobina A2: } 3,9 \% \text {; hemoglobina fetal: 1,9 \%; } \\
\text { hemoglobina S: } 32,2 \% \text {. Avaliação das hemoglobinas: } \\
\text { método realizado por cromatografia líquida de alta } \\
\text { performance (HPLC). }\end{array}$ & PNCQ \\
\hline $\begin{array}{l}\text { Hemoglobina SS, hemoglobina A1: } 3,0 \% \text {; hemoglobina } \\
\text { S: } 97,0 \% \text { Avaliação das hemoglobinas: método } \\
\text { realizado por cromatografia líquida de alta performance } \\
\text { (HPLC). }\end{array}$ & Aldrich \\
\hline
\end{tabular}




\subsubsection{Material biológico}

Todas as amostras foram tratadas como potencialmente infectantes, portanto, as amostras foram manuseadas de acordo com seus respectivos EPI's (equipamentos de proteção individual). O descarte do rejeito biológico foi feito de acordo com os procedimentos laboratoriais locais e normas aplicáveis.

Neste trabalho foram utilizados padrões de sangue liofilizados comercializados pelo Programa Nacional de Controle de Qualidade PNCQ (Rio de Janeiro/RJ) e Sigma Aldrich (EUA) para os ensaios biológicos e para as medidas espectroscópicas. Os padrões de sangue total liofilizados utilizados foram: Hemoglobinas Hemoglobina AA, Hemoglobina AS (PNCQ) e Hemoglobina SS (Sigma). Todas essas amostras foram fornecidas com seus respectivos resultados de eletroforese de hemoglobinas pelas respectivas empresas fornecedoras.

\subsection{Metodologia}

\subsubsection{Preparação e estudo dos tampões para análises biológicas}

Os procedimentos para preparação dos tampões seguiram os protocolos estabelecidos de acordo com os fabricantes.

Foram preparadas triplicatas das soluções tampão de fosfato de potássio monobásico e bibásico com concentrações de $1,5 \mathrm{~mol} \mathrm{~L}^{-1}, 1,8 \mathrm{~mol} \mathrm{~L}^{-1}$ e $2,3 \mathrm{~mol} \mathrm{~L}^{-1}$. As triplicatas foram divididas em: i) autoclavadas a $100{ }^{\circ} \mathrm{C}$ por 15 minutos e armazenadas entre 2 e $10^{\circ} \mathrm{C}$; ii) não autoclavadas com adição de 2-cloroacetamida (conservante), e iii) não autoclavadas sem adição de 2-cloroacetamida. 


\subsubsection{Preparação dos reagentes}

Os reagentes, detergentes e agentes redutores, foram pesados para o preparo das diluições: $1: 1 ; 1: 1,5 ; 1: 2 ; 1,5: 1$ e $2: 1$; respectivamente. As concentrações de ambos

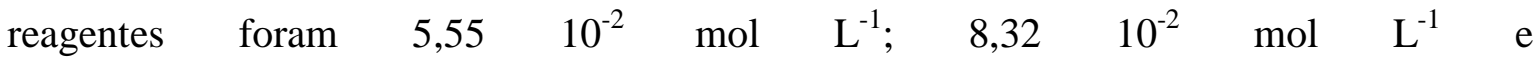
$1,1110^{-1} \mathrm{~mol} \mathrm{~L}^{-1}$.

Na tabela 4.2 pode-se observar a relação entre os detergentes utilizados e os agentes redutores.

TABELA 4.2. Detergentes e agentes redutores testados e suas respectivas diluições.

\begin{tabular}{|c|c|}
\hline $\begin{array}{c}\text { Detergentes }+ \text { Hidrossulfito de } \\
\text { sódio }\end{array}$ & Diluições \\
\hline $\begin{array}{ll}\checkmark & \text { Saponina } \\
\checkmark & \text { Detergente comercial } \\
\checkmark & \text { Tween } 20\end{array}$ & $1: 1 ; 1: 1,5 ; 1: 2 ; 1,5: 1$ e $2: 1$ \\
\hline Detergentes + Ácido cítrico & Diluições \\
\hline $\begin{array}{ll}\checkmark & \text { Saponina } \\
\checkmark & \text { Detergente comercial } \\
\checkmark & \text { Tween } 20\end{array}$ & $1: 1 ; 1: 1,5 ; 1: 2 ; 1,5: 1$ e $2: 1$ \\
\hline Detergentes + Tiossulfato de sódio & Diluições \\
\hline $\begin{array}{ll}\checkmark & \text { Saponina } \\
\checkmark & \text { Detergente comercial } \\
\checkmark & \text { Tween } 20\end{array}$ & $1: 1 ; 1: 1,5 ; 1: 2 ; 1,5: 1$ e $2: 1$ \\
\hline $\begin{array}{l}\text { Detergentes + Peróxido de } \\
\text { hidrogênio }\end{array}$ & Diluições \\
\hline $\begin{array}{ll}\checkmark & \text { Saponina } \\
\checkmark & \text { Detergente comercial } \\
\checkmark & \text { Tween } 20\end{array}$ & $1: 1 ; 1: 1,5 ; 1: 2 ; 1,5: 1$ e $2: 1$ \\
\hline
\end{tabular}


Foram misturados $10 \mathrm{~mL}$ do tampão de fosfato de potássio de $1,5 \mathrm{~mol} \mathrm{~L}^{-1}$, com suas respectivas concentrações de detergentes e agentes redutores nas relações citadas acima.

Para o preparo do tampão fosfato de potássio de $1,8 \mathrm{~mol} \mathrm{~L}^{-1}$ e $2,3 \mathrm{~mol} \mathrm{~L}^{-1}$ foi utilizado o mesmo procedimento descrito anteriormente.

As soluções estoque foram submetidas a vigorosas agitações e mantidas entre $2{ }^{\circ} \mathrm{C}$ e $10{ }^{\circ} \mathrm{C}$ por um período de 12 horas (overnight).

\subsubsection{Síntese do marcador de európio}

\subsubsection{Síntese do $\beta$-dicetonato de európio hidratado}

A síntese do 2-tenoiltrifluoroacetonato (TTA) de európio di-hidratado foi representada pela figura 4.1. Dissolvendo-se cerca de 6,7 g (0,03 mol) do TTA em $50 \mathrm{~mL}$ de etanol 95\%, moderamente aquecido $\left(\sim 50{ }^{\circ} \mathrm{C}\right)$. Adicionou-se a essa solução alcoólica cerca de 0,03 mols de hidróxido de sódio até atingir $\mathrm{pH} 7,0$. À solução foi adicionado 0,01 mol de $\mathrm{EuCl}_{3}: 6 \mathrm{H}_{2} \mathrm{O}$ dissolvido em $50 \mathrm{~mL}$ de água. Após a mistura o $\mathrm{pH}$ baixou para $3 \mathrm{e}$ mais solução de $\mathrm{NaOH}$ foi requerida para que a solução atingisse o $\mathrm{pH}$ de aproximadamente 6,5. A mistura foi agitada durante 2 horas, até que se formasse um óleo, seguido da precipitação do complexo na forma de um pó fino amarelo claro ${ }^{[3]}$.

\subsubsection{Síntese do complexo $\left[\mathrm{Eu}(\mathrm{TTA})_{3}(4-\text { picNO })_{2}\right]$ - marcador de európio}

O complexo do TTA de európio com 4-picolina-N-óxido como ligante foi representada pela figura 4.2. A partir do complexo hidratado com a 4-picNO, ambos dissolvidos em acetona e numa razão molar metal:ligante igual a 1:3. Após a evaporação da acetona o precipitado formado foi lavado com água, recristalizado e filtrado, com o objetivo de extrair o excesso de ligante. O complexo na forma de pó foi seco e armazenado em dessecador sob vácuo. 


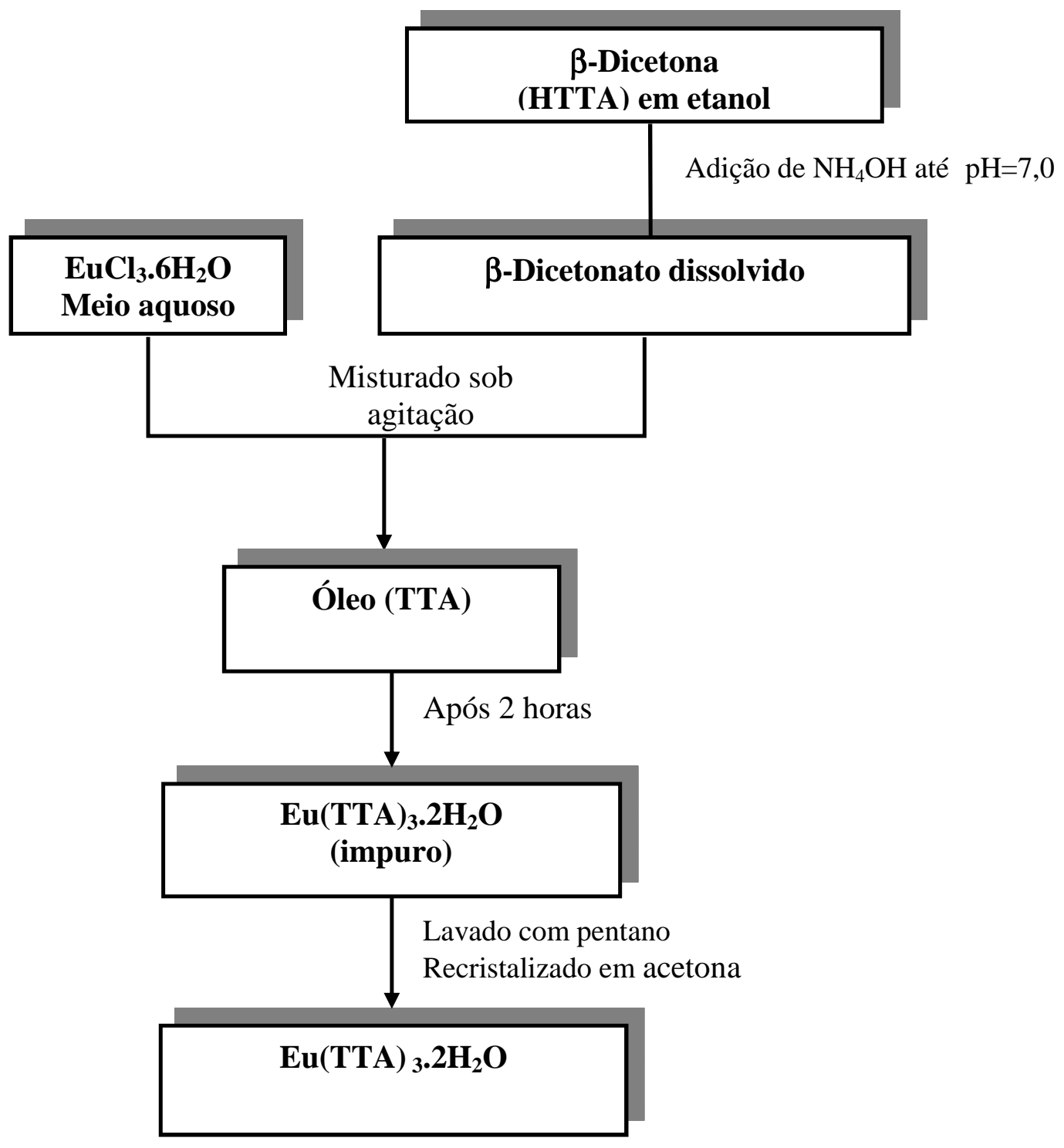

FIGURA 4.1. Rota de síntese dos complexos hidratados $\left[\mathrm{Eu}(\mathrm{TTA})_{3}\left(\mathrm{H}_{2} \mathrm{O}\right)_{2}\right]$. 


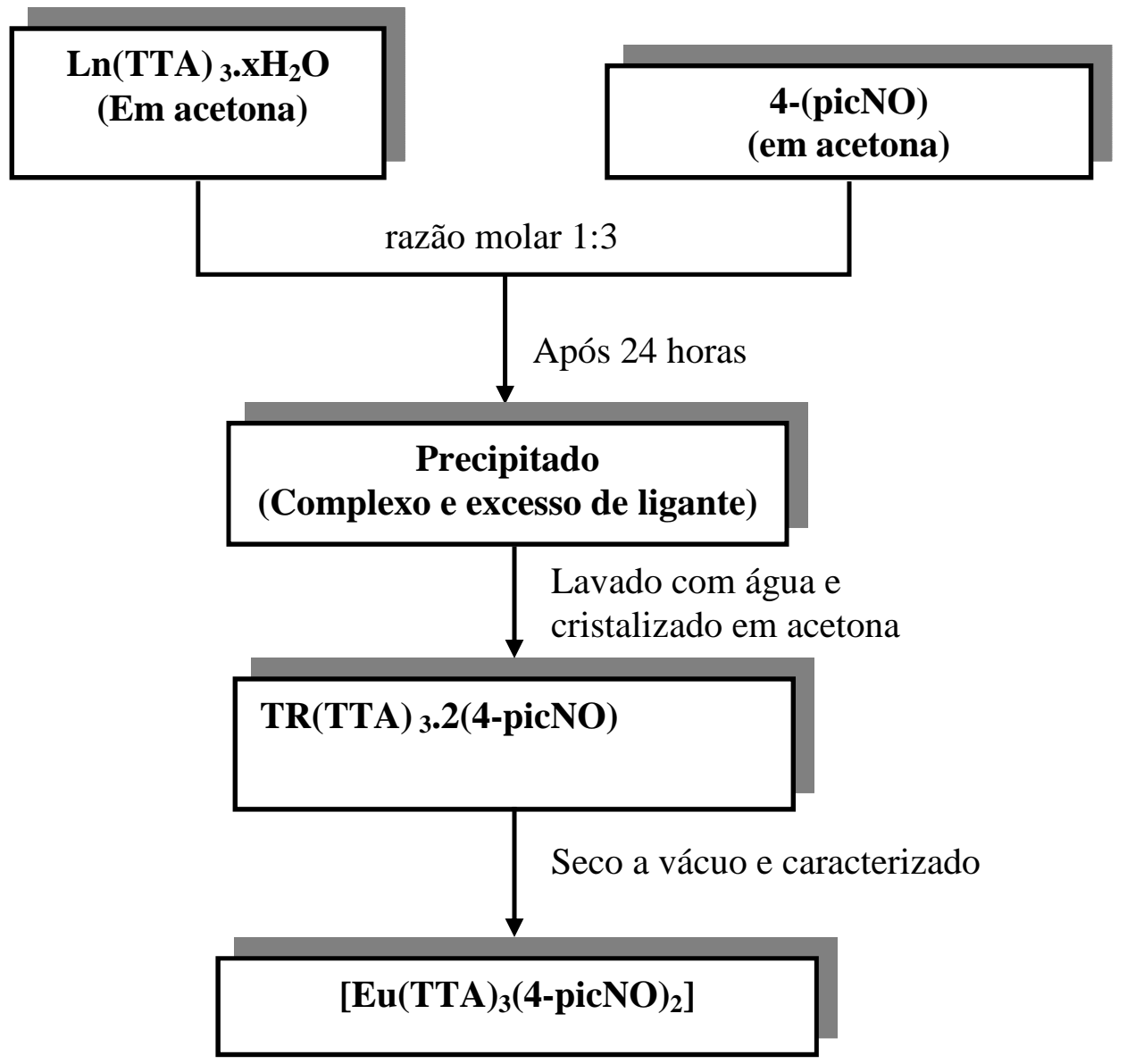

FIGURA 4.2. Rota de síntese dos complexos $\left[\mathrm{Eu}(\mathrm{TTA})_{3}(4-\mathrm{picNO})_{2}\right]$.

\subsubsection{Caracterização do marcador $\left[\mathrm{Eu}(\mathrm{TTA})_{3}(4-\mathrm{picNO})_{2}\right]$}

Para caracterização do marcador neste trabalho utilizaram-se as técnicas: análise elementar $\mathrm{CHN}$, análise complexométrica para detecção da porcentagem de Eu, infravermelho, difração de raios x, microscopia eletrônica de varredura e espectroscopia de luminescência como listado a seguir.

\subsubsection{Análises elementar de carbono, hidrogênio e nitrogênio}

As medidas das percentagens de carbono, hidrogênio e nitrogênio para os ligantes e complexos foram realizadas utilizando-se um microanalisador $\mathrm{CHN}$, modelo 
2400 Perkin Elmer pertencente ao laboratório da Central Analítica do Instituto de Química da USP-São Paulo.

\subsubsection{Percentagem de íon terra rara trivalente $\mathrm{Eu}^{3+}$}

A determinação quantitativa do íon $\mathrm{TR}^{3+}$ nos complexos foi feita através da titulação complexométrica utilizando $\operatorname{EDTA}\left(0,01 \mathrm{~mol} \cdot \mathrm{L}^{-1}\right)$ como agente complexante e alaranjado de xilenol como indicador (solução $1 \%$ em peso). Pesou-se aproximadamente $20 \mathrm{mg}$ do complexo o qual foi dissolvido em metanol (P.A.) seguido da adição de 1 gota de piridina, $3 \mathrm{~mL}$ de uma solução tampão ácido acético/acetato de sódio com pH 5,8 e 3 gotas do indicador ${ }^{[4,5]}$. Nessas condições iniciais a solução de cor violeta atinge uma coloração amarela no ponto de viragem da titulação.

\subsubsection{Espectros de absorção na região do infravermelho}

Os espectros de absorção na região do infravermelho foram registrados em pós usando a técnica de ATR utilizando-se um espectrofotômetro Thermo Scientific Nicolet 6700 FT-IR do laboratório de Polímeros do Ipen.

\subsubsection{Difração de Raios $X$ (métodos do pó e monocristal)}

Os difratogramas de raios $\mathrm{X}$ (método do pó) dos complexos foram registrados através de um difratômetro de raios X MINIFLEX II - RIGAKU utilizando radiação $\mathrm{CuK}_{\alpha}$ de $\lambda=1,5425 \AA$. 


\subsubsection{Microscopia eletrônica de varredura}

A microscopia eletrônica de varredura (MEV) foi utilizada para determinar a dispersão das partículas, bem como as características superficiais desta. As amostras foram dispersas em tampão fosfato de potássio $(\mathrm{pH} 7,2)$ e depositadas em um suporte de grafite ${ }^{[6]}$ utilizou-se e um MEV de bancada da marca Hitachi High Technologies modelo NeoScope JCM5000, e neste tipo de equipamento não é necessário o recobrimento metálico das amostras, foi utilizado uma potencia de $15 \mathrm{KV}$ e alto vácuo.

Podem ser utilizados dois tipos de detectores que captam raios-X característicos: por dispersão de energia (EDS) ou por dispersão em comprimento de onda (WDS). O detector é capaz de determinar a energia dos fótons que ele recebe, tornando possível traçar um histograma com a abscissa sendo a energia dos fótons (keV) e a ordenada o número de fótons recebidos (contagens).

\subsubsection{Espectros de luminescência}

Os espectros de luminescência (excitação e emissão) foram obtidos em temperatura ambiente e nitrogênio líquido $(77 \mathrm{~K})$ em um espectrofluorímetro SPEXFLUOROLOG 3 (controlado pelo programa computacional FluorEssence ${ }^{\mathrm{TM}}$ no Windows(®) com monocromadores duplos SPEX 1680 utilizando lâmpada de Xenônio de $450 \mathrm{~W}$ como fonte de excitação. Os dados espectrais foram coletados em um ângulo de $22,5^{\circ}$ (face frontal). As fendas de excitação e de emissão foram utilizadas com aberturas entre 0,1 e 2,0 mm e com um CCD Synapse Horiba Jobin Yvon MCD1400BR-2612 para detecção. Todos esses aparatos foram controlados via programa computacional Fluoressence V3.5.

Todas as medidas de espectrofotometria foram obtidas nos equipamentos pertencentes ao Laboratório dos Elementos do Bloco $f(\mathrm{LEB} f)$, do Instituto de Química da USP (IQ-USP) - São Paulo. 


\subsection{Ensaio biológico}

Todo reagente e material derivado de sangue humano, inclusive as amostras de pacientes, foram manuseadas como potencialmente infectantes. De acordo com o fabricante recomenda-se que a manipulação destes reagentes e das amostras humanas seja realizada de acordo com as Boas Práticas de Laboratório que é descontaminar e descartar amostras e todos os materiais potencialmente contaminados como se contivessem agentes infecciosos.

Para o ensaio biológico os padrões liofilizados foram reconstituídos em água ultra pura (MiliQ) de acordo com norma técnica dos fornecedores e permaneceram sob agitação por 10 minutos à temperatura ambiente.

Os detergentes e agentes redutores foram pesados e colocados nos seus respectivos tubos de ensaio de acordo com TAB. 4.2.

As soluções tampão estoque foram retiradas do refrigerador e de cada uma retirou-se 2,0 mL para os tubos de ensaio que foram agitados vigorosamente para que os detergentes e agentes redutores se dissolvessem completamente.

As soluções tampão estoque foram armazenadas em temperatura entre $2{ }^{\circ} \mathrm{C}$ e $10{ }^{\circ} \mathrm{C}$.

Os tubos de ensaio permaneceram a temperatura ambiente e em seguida neles foram adicionados $20 \mu \mathrm{l}$ de sangue, $\mathrm{Hb} \mathrm{AA}, \mathrm{Hb}$ AS e Hb SS em cada condição descrita na TAB. 4.2.

Logo, foi gotejado $20 \mu \mathrm{l}$ da mistura final (sangue, solução tampão, detergente e agente redutor), de cada amostra, no papel cromatográfico, FIG. 4.3. Esperou-se por 5 minutos para a formação dos halos das diferentes amostras, FIG. 4.3. Os resultados foram fotografados para avaliação.

Os dados obtidos a partir desta metodologia foram comparados com os resultados do kit comercial. 


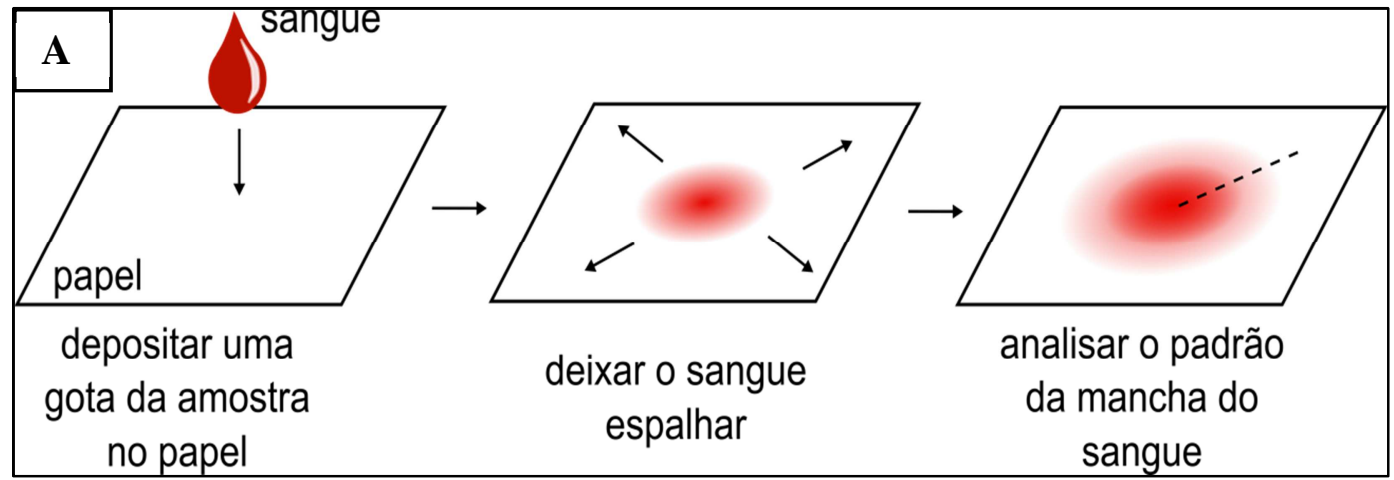

B

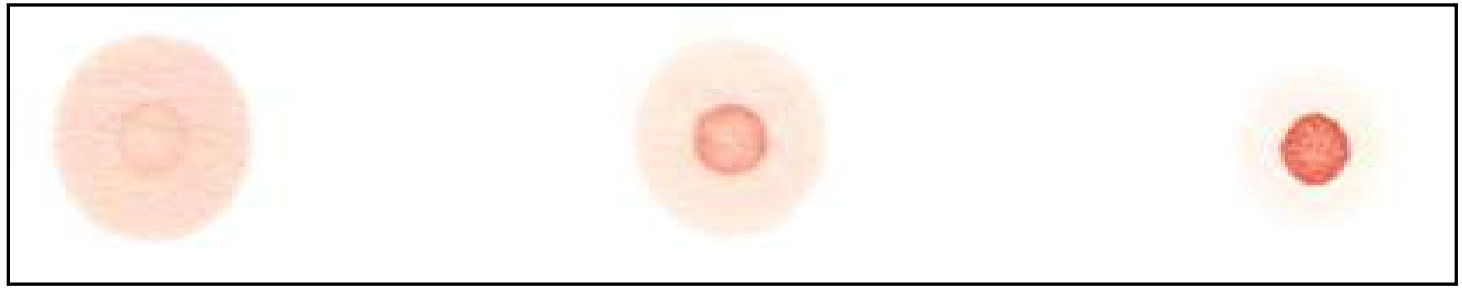

Hb AA

Hb AS

Hb SS

FIGURA 4.3. A: Ilustração esquemática do princípio básico do ensaio biológico em papel de cromatografia. Foi depositado $20 \mu \mathrm{l}$ da mistura final sobre o substrato de papel para análise da formação dos halos. B: Pode-se observar, da esquerda para a direita, halo claro: indicativo da presença apenas da $\mathrm{Hb} \mathrm{AA}$; halo com anel escuro no centro: indicativo da presença de $\mathrm{Hb} \mathrm{AS}$; halo escuro e uniforme: indicativo da presença de $\mathrm{Hb}$ SS.

\subsubsection{Conjugação do complexo de európio para atuar como marcador}

A conjugação do complexo de $\left[\mathrm{Eu}(\mathrm{TTA})_{3}(4 \text {-picNO })_{2}\right]$ com hemoglobinas foi realizada juntando-se soluções da hemoglobina com o tampão em estudo e $40 \mu \mathrm{L}$ de uma dispersão aquosa contendo o complexo de $\left[\mathrm{Eu}(\mathrm{TTA})_{3}(4-\mathrm{picNO})_{2}\right]$. A reação foi comprovada através da comparação entre os espectros de excitação e emissão. 


\subsection{Diferenciação das amostragens biológicas por espectroscopia Raman e Espectroscopia de Infravermelho por Transformada de Fourier (FTIR)}

As técnicas de espectroscopia Raman e FTIR foram utilizadas neste trabalho como um método complementar e comparativo aos ensaios biológicos. Portanto, foram feitas medidas espectrais para serem usadas como uma possível ferramenta comparativa entre os resultados obtidos.

Para espectroscopia Raman foi utilizado um FT-Raman Bruker que permite a obtenção de espectros FT-Raman usando como fonte de excitação um laser Nd:YAG (COHERENT Compass) que cobriu uma faixa espectral de $3500-450 \mathrm{~cm}^{-1}$, com excitação em $1064 \mathrm{~nm}$, e uma potência de laser de $80 \mathrm{~mW}$. Este espectrômetro possui um detector de Germânio refrigerado com nitrogênio líquido e um microscópio óptico da Nikon®, modelo Eclipse E-400, acoplado que permitiu a escolha da região de excitação da amostra. O equipamento pertence ao laboratório de espectroscopia vibracional do Instituto de Química da USP (IQ).

Para espectroscopia de infravermelho foi utilizado um espectrômetro de reflectância total atenuada (ATR) por transformada de Fourier que cobriu a região espectral: 4000-400 $\mathrm{cm}^{-1}$ da marca Bruker Alpha, modelo Platinium ATR. Este equipamento foi adquirido pelo laboratório de espectroscopia vibracional do Instituto de Química da USP (IQ).

Para o processamento dos resultados obtidos com o infravermelho e espectroscopia Raman, o pacote computacional estatístico utilizado foi o Minitab®, que supriu as operações necessárias para o cálculo das análises de componentes principais (PCA, Principal Component Analysis), inclusive no tratamento prévio de padronização dos dados estatísticos e escalonamento dos dados.

Para as técnicas de espectroscopia citadas acima foram criados banco de dados do: grupo de referência: aminoácidos valina e ácido glutâmico; grupo controle Hb AA; grupo alvo $\mathrm{Hb}$ AS e grupo alvo $\mathrm{Hb} \mathrm{SS}$. 


\section{REFERÊNCIAS BIBLIOGRÁFICAS}

[1] MOHR, O.; Microchemie, v. 2, p. 154, 1930.

[2] MORITA, I.; ASSUMPÇÃO, R.M.V. Manual de Soluções, Reagentes e Solventes. São Paulo: Edgard Blucher, 1972.

[3] CHARLES, R.G.; OHLMANN, R.C. Europium thenoyltrifluoroacetonate, preparation and fluorescence properties. J. Inorg. Nucl. Chem., v. 27, p. 255-259, 1965.

[4] LYLE, S.J.; WITTS, A.D. A critical examination of some methods for the preparation of tris and tetrakis diketonates of europium (III). Inorg. Chim. Acta, v. 5, p. 481-484, 1971.

[5] LYLE, S.J.; RAHMAN, M.M. Complexometric titration of yttrium and the lanthanons - I. Talanta, v. 10, p. 1177-1182, 1963.

[6] PAGANINI, P.P. Síntese e caracterização de trocadores iônicos inorgânicos a base de óxidos mistos estanho-titânio para utilização na recuperação de cádmio e níquel e estudos fotoluminescentes. 2007. Dissertação (Mestrado), Instituto de Pesquisas Energéticas e Nucleares, IPEN/CNEN-SP, São Paulo. 
5

\section{Resultados e Discussão}




\subsection{Síntese e caracterização do marcador luminescente [Eu(TTA $)_{3}(2 \text { picNO })_{2}$ ]}

O composto sintetizado mostra-se estável em condições ambiente $\left(\sim 25^{\circ} \mathrm{C}\right)$, ele é solúvel nos solventes: acetona, clorofórmio e parcialmente solúvel em etanol. O complexo, após a evaporação do solvente no processo de síntese, precipitou na forma de um pó fino.

Os dados de microanálises de $\mathrm{C}, \mathrm{H}$ e $\mathrm{N}$ (em percentagem) calculados e experimentais (Calc./Exp.) do complexo em questão são C (45,00/45,15), H(3,69/3,61), $\mathrm{N}(2,50 /, 2,45)$. A percentagem de Eu foi obtida via titulação complexométrica com complexante EDTA $(13,56 / 13,27)$.

Na FIG. 5.1 pode-se visualizar o complexo marcador obtido sob irradiação no ultravioleta com excitação em $\lambda=366 \mathrm{~nm}$.

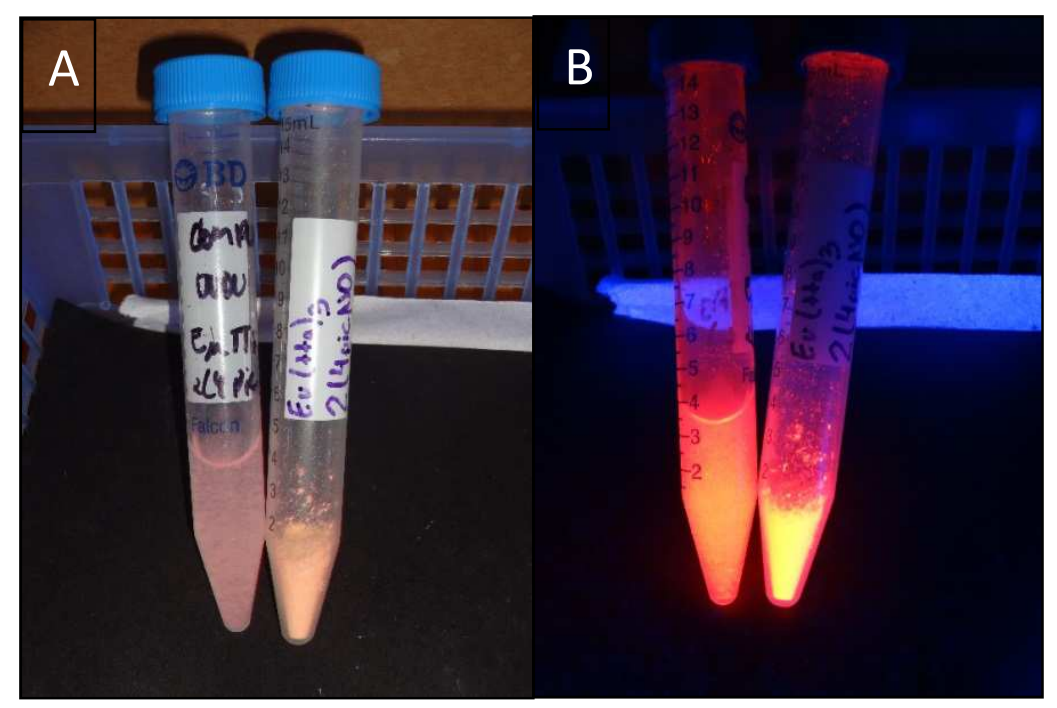

FIGURA 5.1. Complexo $\left[\mathrm{Eu}(\mathrm{TTA})_{3}(4-\mathrm{picNO})_{2}\right]$ : (A) ausência de radiação solar e (B) presença de radiação ultravioleta $(366 \mathrm{~nm})$. 


\subsubsection{Espectroscopia de absorção na região do infravermelho}

Os espectros vibracionais na região do infravermelho fornecem valiosas informações a respeito da natureza dos grupos carbonílicos dos $\beta$-dicetonatos e picolinatos ligados aos íons metálicos nos compostos de coordenação ${ }^{[1,2]}$. As principais bandas envolvidas nos estudos da interação $\beta$-dicetonatos-íon metálico são aquelas associadas às frequências de estiramento $v_{\mathrm{s}}(\mathrm{C}=\mathrm{O}) \quad\left(\sim 1600 \mathrm{~cm}^{-1}\right), \mathrm{v}_{\text {ass }}(\mathrm{C}=\mathrm{O}) \quad\left(\sim 1400 \mathrm{~cm}^{-1}\right), v_{\mathrm{s}}(\mathrm{C}=\mathrm{C})$ $\left(1531 \mathrm{~cm}^{-1}\right)$ e $\mathrm{v}\left(\mathrm{O}-\mathrm{M}^{\mathrm{n}+}\right)\left(\sim 450 \mathrm{~cm}^{-1}\right)^{[3]}$. O comportamento dos modos vibracionais $\mathrm{v}(\mathrm{C}=\mathrm{O})$ e $v(C=C)$ nos $\beta$-dicetonatos foram intensivamente estudados por Holtzclaw e Collman ${ }^{[4]}$, que sugeriram que o caráter de ligação dupla $\mathrm{C}=\mathrm{C}$ no anel quelante dos $\beta$-dicetonatos é relativamente fraca e que a frequência de absorção do grupo carbonila está relacionado com:

i) A densidade eletrônica relativa das ligações $\sigma$, que são geralmente controladas pelos grupos substituintes ligados aos carbonos carbonílicos;

ii) A massa dos grupos substituintes ligados aos grupos carbonílicos;

iii) A interação dos grupos carbonílicos com os orbitais do íon metálico.

Nakamoto e colaboradores ${ }^{[5]}$ fizeram um estudo comparativo entre os espectros dos complexos acetilacetonato e seus derivados contendo os grupos substituintes alquil, aril e fluorometil. Nesse estudo, foi observado que as substituições do grupo metila no acetilacetonato por grupos trifluorometil, resultando o trifluoro $\mathrm{e}$ hexafluoroacetilacetonatos, causam deslocamentos das freqüências de estiramento $\mathrm{C}=\mathrm{O}$ e $\mathrm{C}=\mathrm{C}$ para regiões de freqüências maiores e $\mathrm{M}-\mathrm{O}$ no sentido contrário. Esse comportamento é explicado com base no efeito indutor negativo (receptor de elétrons) do grupo $\mathrm{CF}_{3}$ que faz com que haja uma diminuição na densidade eletrônica na ligação M-O e um aumento na densidade envolvendo o grupo quelante do dicetonato. Quando os grupos $\mathrm{CH}_{3}$ foram substituídos por grupos fenilas houve um aumento nos estiramentos M-O, no entanto, foi observado uma irregularidade nas frequências de estiramento $\mathrm{C}=\mathrm{O}$ e $\mathrm{C}=\mathrm{C}$. Isto se deve às interações mesoméricas do grupo fenila com o anel quelante quase-aromático, que conduz a um deslocamento nos elétrons $\pi$ do anel quelante de acordo com as estruturas mostradas na FIG. 5.2. As estruturas II e III, que apresentam uma carga negativa sobre o átomo de 
oxigênio, são mais significativas nos complexos de íons metálicos que pode formar ligações $\pi$ com o $\beta$-dicetonato, conduzindo a um aumento na frequência de estiramento da ligação M-O e um efeito contrário para a ligação $\mathrm{C}=\mathrm{O}$. Por outro lado, a estrutura $\mathrm{I}$ tem maior contribuição nos complexos com íons de metais alcalinos terrosos, uma vez que estes íons não formam ligações $\pi$ e, neste caso, são esperados deslocamentos das frequências das ligações $\mathrm{M}-\mathrm{O}$ e $\mathrm{C}=\mathrm{O}$ para energias maiores.

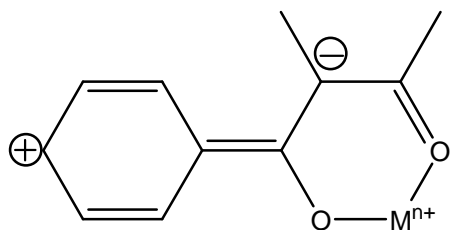

I

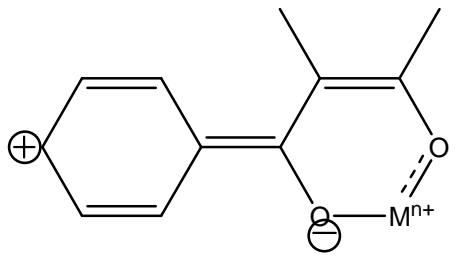

II

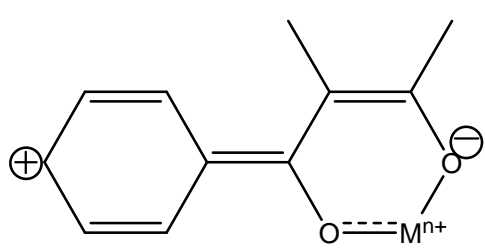

III

FIGURA 5.2. Efeito mesoiônico do grupo fenila nos complexos com $\beta$-dicetonatos.

O ligante 4-picNO utilizado neste trabalho pertence à classe dos aminóxidos aromáticos. No complexo metálico formado com este ligante a interação M-ligante ocorre através do átomo de oxigênio do grupo $\mathrm{N}=\mathrm{O}$ e pode ser avaliada pelos deslocamentos característicos de várias bandas dos ligantes no espectro do complexo, na região do infravermelho.

As atribuições mais intensas que se observam nos espectros de infravermelho dos aminóxidos aromáticos ocorrem na região de 1200 à $1300 \mathrm{~cm}^{-1}$ e são devidas às frequências de estiramento do grupo $\mathrm{N}=\mathrm{O}^{[6]}$. Na coordenação dos aminóxidos aromáticos ao íon metálico, esta absorção, em geral, aparece em regiões de menor frequência em relação ao ligante livre ${ }^{[7,8]}$, e o deslocamento dependerá da força da ligação metal-ligante. A formação da ligação O-M aumenta a demanda de elétrons do átomo de oxigênio doador, portanto conduzindo a um decréscimo no caráter de dupla ligação do 
grupo $\mathrm{N}+\mathrm{O}^{[7]}$, isto conduz a deslocamentos negativos para vN-O. Para os complexos onde o íon metálico é um lantanídeo este deslocamento é da ordem de $40 \mathrm{~cm}^{-1[9,10]}$.

Para a frequência de deformação NO no plano $\left(\delta_{\mathrm{NO}}\right)$ em complexos metálicos, deveria-se esperar deslocamentos consistentes em relação ao ligante livre. Entretanto, a experiência tem mostrado pequenas variações ou praticamente nenhum deslocamento deste modo vibracional quando da coordenação com o metal. Pode-se explicar este fato levandose em consideração as seguintes premissas: a) a ligação do átomo metálico ao grupo NO causa deslocamento vibracional para frequências maiores; b) o decréscimo no caráter de dupla ligação da interação N-O, devido a coordenação, conduz a deslocamentos para frequências mais baixas.

As bandas de deformação C-H fora do plano $(\gamma \mathrm{CH})$ são geralmente deslocadas para frequências mais altas na complexação. Tais deslocamentos são atribuídos ao decréscimo na densidade eletrônica do anel que ocorre em função da coordenação do ligante ao metal através do oxigênio do grupo $\mathrm{NO}^{[8,10]}$.

$\mathrm{Na}$ FIG. 5.3 apresenta-se o espectro de Infravermelho do complexo $\left[\mathrm{Eu}(\mathrm{TTA})_{3}(4-\text { picNO })_{2}\right]$ onde pode-se observar as bandas referentes a coordenação deste ligante ao complexo tris tenoilacetonato de europio(III) dihidratado. Foram atribuídas bandas referentes ao estiramento do grupo carboxílico da $\beta$-dicetona em 1597 e $1523 \mathrm{~cm}^{-1}$, as quais são atribuídas aos modos de estiramento $v(C=O)$ e a uma mistura de $v(C=C)$ e $v(\mathrm{C}=\mathrm{O})$, respectivamente. Esse resultado sugere que a $\beta$-dicetona, TTA, atua como quelante coordenando-se aos íons $\mathrm{Eu}^{3+}$ através dos átomos de oxigênio dos grupos carbonilas. Já a coordenação do ligante 4-picNO foram relacionadas com as seguintes bandas: vNO em 1298-1238 cm ${ }^{-1}$, vibração no plano $(\beta C H)$ em 1174 e 1124 , vibração $C-H$ fora do plano em 931, 852 e $783 \mathrm{~cm}^{-1}$. A banda centrada em $852 \mathrm{~cm}^{-1}$ é alargada devido a deconvolução de dois picos que deveriam estar em 860 e $830 \mathrm{~cm}^{-1}$ que são atribuídos a $\delta \mathrm{N}=\mathrm{O}$ e $\gamma \mathrm{C}-\mathrm{H}$ fora do plano. 


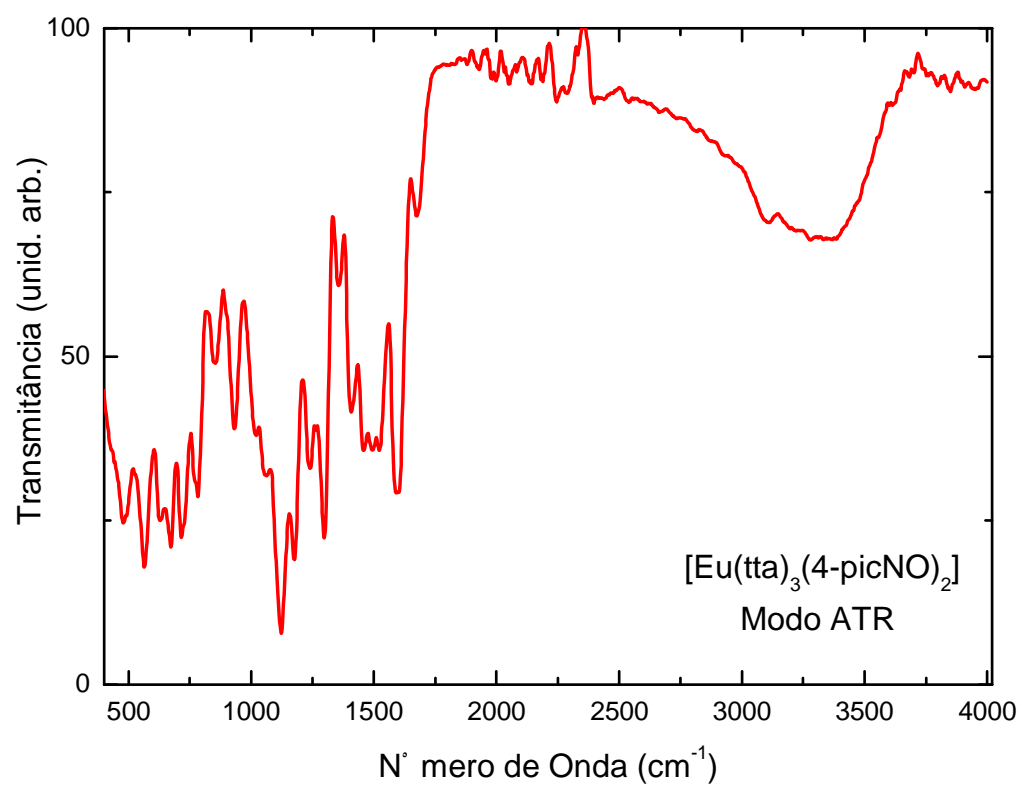

FIGURA 5.3. Espectro de Infravermelho do complexo $\left[\mathrm{Eu}(\mathrm{TTA})_{3}(4-\mathrm{picNO})_{2}\right]$.

\subsubsection{Raios $X$}

Os difratogramas de raios $\mathrm{X}$ pelo método do pó têm sido muito úteis na análise estrutural de compostos de coordenação de terras raras, principalmente quando estes apresentam o fenômeno de isomorfismo estrutural para uma mesma série de elementos ou ligante. De acordo com os dados do difratograma, FIG. 5.4, do complexo marcador podese observar que o composto apresenta-se cristalino ${ }^{[11]}$. 


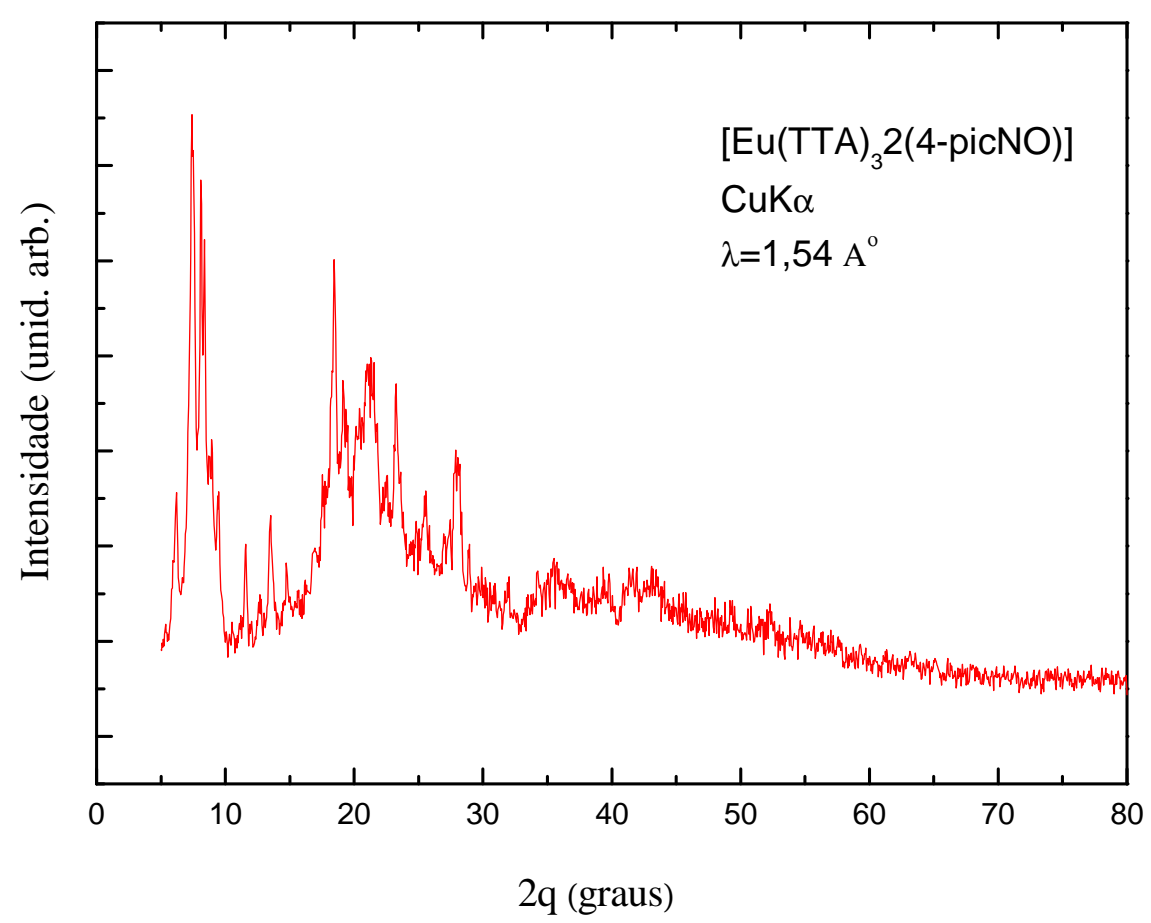

FIGURA 5.4. Difratograma de raios $X$ do complexo $\left[\mathrm{Eu}(\mathrm{TTA})_{3}(4-\mathrm{picNO})_{2}\right]$.

\subsubsection{Microscopia eletrônica de Varredura (MEV)}

Na FIG. 5.5 Apresenta-se a microscopia eletrônica de varredura do complexo marcador disperso em solução tampão fosfato. A imagem mostra cristalizações lineares do tampão e pequenos cristais hexagonais distorcidos do complexo de [Eu(TTA $\left.)_{3}(4-\text { picNO })_{2}\right]$. 


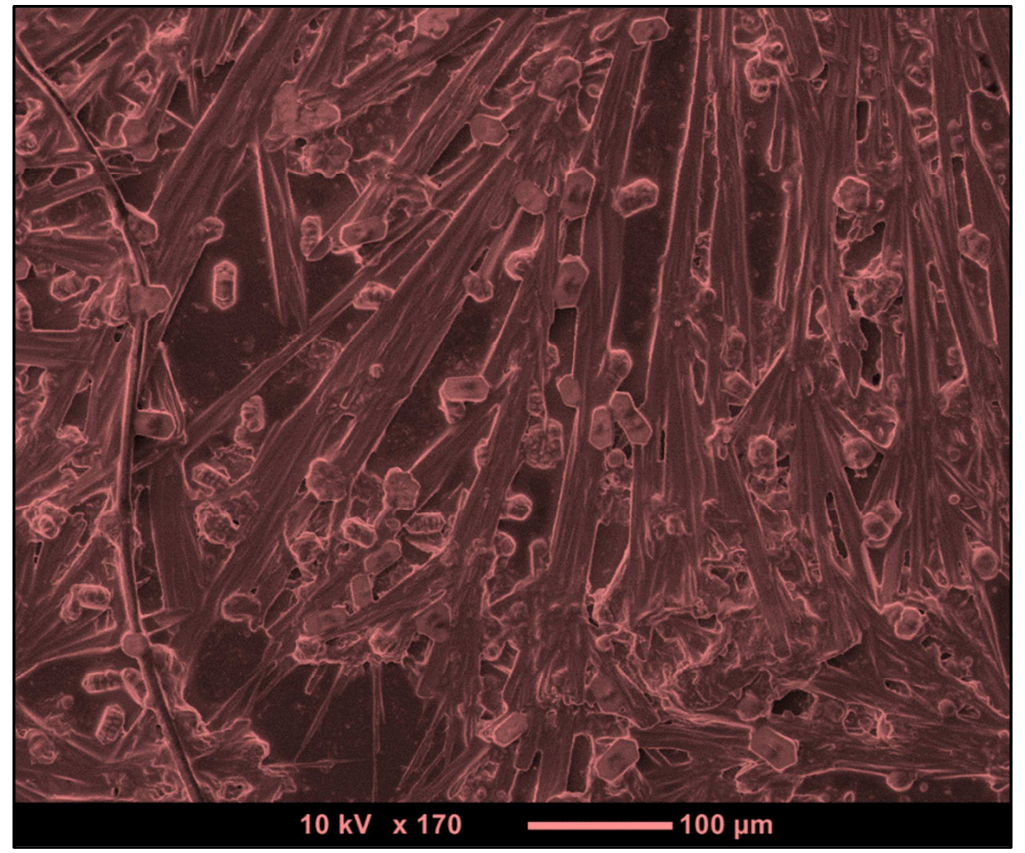

FIGURA 5.5. MEV. Imagem do complexo de $\left[\mathrm{Eu}(\mathrm{TTA})_{3}(4-\mathrm{picNO})_{2}\right]$.

\subsubsection{Estudo fotoluminescente do complexo de $\mathrm{Eu}^{3+}$ marcador}

Os compostos contendo o íon $\mathrm{Eu}^{3+}$ (configuração $[\mathrm{Xe}] 4 \mathrm{f}^{6}$ ) têm sido extensivamente estudados por apresentarem alta luminescência monocromática de cor vermelha. Além disso, a partir de seus espectros de emissão pode-se obter informações sobre o desdobramento do campo ligante, processos de transferência de energia e eficiência quântica do estado emissor. Os espectros exibidos pelos complexos de $\mathrm{Eu}^{3+}$ apresentam, principalmente, bandas oriundas das transições intraconfiguracionais ${ }^{5} \mathrm{D}_{0} \rightarrow{ }^{7} \mathrm{~F}_{\mathrm{J}}$ (onde $\mathrm{J}=0,1,2,3,4,5$ e 6), sendo que as transições ${ }^{5} \mathrm{D}_{0} \rightarrow{ }^{7} \mathrm{~F}_{5}$ e ${ }^{5} \mathrm{D}_{0} \rightarrow{ }^{7} \mathrm{~F}_{6}$ apresentam intensidade muito baixa e dificilmente são observadas nos espectros dos compostos de coordenação. Como pode ser observado, o principal nível emissor ${ }^{5} \mathrm{D}_{0}$ é não degenerado e não se desdobra em qualquer simetria em torno do íon metálico ${ }^{[12]}$, ao contrário, por exemplo, do estado emissor do $\mathrm{Tb}^{3+}\left({ }^{5} \mathrm{D}_{4}\right)$ que tem uma degenerescência igual a nove. Portanto, o número máximo de bandas resultantes de uma transição ${ }^{5} \mathrm{D}_{0} \rightarrow{ }^{7} \mathrm{~F}_{\mathrm{J}}$ é dado pela regra de $(2 \mathrm{~J}+1)$-componentes. $\mathrm{O}$ número de bandas associado a cada transição depende da simetria pontual ao redor do íon $\mathrm{TR}^{3+}$ e pode ser facilmente determinada usando a teoria de $\operatorname{grupos}^{[13]}$. 
Quando um espectro apresenta número de picos maior do que da regra (2J+1)componentes isto evidencia ou presença de mais de um sítio de simetria para o íon metálico ou que o composto está impuro, por exemplo, em sistemas dinucleares sem centro de inversão, ou mistura de isômeros, ou ainda o aparecimento de transições vibrônicas devido à interação dos níveis eletrônicos e estados de densidade fônons. Este último fenômeno resulta na presença de "bandas satélites" e é observado principalmente nas transições ${ }^{5} \mathrm{D}_{0} \rightarrow{ }^{7} \mathrm{~F}_{2}$, considerando que o nível ${ }^{7} \mathrm{~F}_{2}$ encontra-se na região espectral correspondente as frequências de estiramentos $v(C=O), v(C=C)$ e $v(N=O)$ presentes nos ligantes orgânicos.

As transições ${ }^{5} \mathrm{D}_{0} \rightarrow{ }^{7} \mathrm{~F}_{0,3,5}$ são proibidas pelas regras de seleção de dipoloelétrico forçado e dipolo-magnético. No entanto, a primeira regra pode ser relaxada pelo campo ligante conduzindo aos efeitos de misturas dos J's e, consequentemente, apesar de pequeno, existe um momento de transição diferente de zero. A intensidade da transição ${ }^{5} \mathrm{D}_{0} \rightarrow{ }^{7} \mathrm{~F}_{0}$ tem sido caracterizada como sendo, principalmente, devido à mistura do estado ${ }^{7} \mathrm{~F}_{2}$ dentro do estado ${ }^{7} \mathrm{~F}_{0}$, e essa mistura é expressa em termos do parâmetro $\mathrm{R}_{02}$, definido como a razão entre as intensidades das bandas oriundas das transições ${ }^{5} \mathrm{D}_{0} \rightarrow{ }^{7} \mathrm{~F}_{0}$ e ${ }^{5} \mathrm{D}_{0} \rightarrow{ }^{7} \mathrm{~F}_{2}$. Por outro lado, a transição ${ }^{5} \mathrm{D}_{0} \rightarrow{ }^{7} \mathrm{~F}_{1}$ é permitida somente por dipolo-magnético e sua intensidade é praticamente insensível ao ambiente químico nas vizinhanças do íon $\mathrm{Eu}^{3+}$, por conseguinte, essa transição tem sido tomada como uma referência interna ${ }^{[14]}$.

As transições ${ }^{5} \mathrm{D}_{0} \rightarrow{ }^{7} \mathrm{~F}_{2,4}$ são permitidas por dipolo-elétrico forçado, sendo que a transição ${ }^{5} \mathrm{D}_{0} \rightarrow{ }^{7} \mathrm{~F}_{2}(\sim 612 \mathrm{~nm})$, hipersensível ao ambiente químico do íon central, é geralmente dominante em compostos não-centrossimétricos. Estas transições fornecem informações se grupo o pontual em torno do íon $\mathrm{Eu}^{3+}$ apresenta centro de inversão, considerando que em compostos centrossimétricos as transições $\quad{ }^{5} \mathrm{D}_{0} \rightarrow{ }^{7} \mathrm{~F}_{2,4}$ são estritamente proibidas por mecanismo de dipolo elétrico.

Uma vez que as bandas de emissão do íon $\mathrm{Eu}^{3+}$ na região do visível são de fácil interpretação, devido a estrutura dos seus níveis de energia, este íon tem sido utilizado como sonda espectroscópica na obtenção de valiosas informações em sistemas bioinorgânicos, tais como: i) a determinação do número de ambientes químicos ao redor do íon $\mathrm{Eu}^{3+}$ através do número de bandas relativo à transição ${ }^{5} \mathrm{D}_{0} \rightarrow{ }^{7} \mathrm{~F}_{0}$; ii) Constante de 
ligação dos íons biomolécula-Eu ${ }^{3+}$, determinada por curvas de titulação e iii) distância doador-receptor $(\mathrm{R})$, normalmente assumindo o mecanismo de acoplamento dipolo-dipolo $\operatorname{fraco}^{[15]}$.

\subsubsection{Espectros de Excitação}

$\mathrm{O}$ estudo das propriedades fotoluminescentes do $\beta$-dicetonato de európio com ligantes 4-picNO, neste trabalho, foi feito com base nos espectros de excitação e emissão registrados a temperatura ambiente $(\sim 298 \mathrm{~K})$ e a $77 \mathrm{~K}$. Os espectros de excitação foram registrados no intervalo de 250 a $590 \mathrm{~nm}$, com emissão monitorada na transição hipersensível ${ }^{5} \mathrm{D}_{0} \rightarrow{ }^{7} \mathrm{~F}_{2}(\sim 613 \mathrm{~nm})$. Enquanto que os espectros de emissão foram obtidos com excitação no íon $\mathrm{TR}^{3+}(\sim 394 \mathrm{~nm}$ e $464 \mathrm{~nm})$ e via banda do ligante $(\sim 330$ e $340 \mathrm{~nm})$ no intervalo de 420 a $750 \mathrm{~nm}$, correspondente às transições intraconfiguracionais ${ }^{5} \mathrm{D}_{0} \rightarrow$ ${ }^{7} \mathrm{~F}_{0-4}$. É importante salientar, que no espectro de excitação houve o alargamento da banda atribuída a excitação do ligante e desaparecimento de algumas bandas intraconfiguracionais 4f-4f entre os espectros registrados a 298 e $77 \mathrm{~K}$. No entanto, os espectros registrados a $77 \mathrm{~K}$ são melhor resolvidos, devido ao menor acoplamento vibrônico, o que facilita a interpretação dos dados espectroscópicos.

A FIG. 5.6 mostra os espectros de excitação dos complexos de TTA. Na região de 250 a $450 \mathrm{~nm}$, os espectros apresentam uma banda larga com máximos em torno de 330, 340 e $396 \mathrm{~nm}$ as duas primeiras associada à transição permitida $\mathrm{S} \rightarrow \mathrm{S}_{0}$ pertencente ao ligante TTA e a última também associada a transição ${ }^{7} \mathrm{~F}_{0} \rightarrow{ }^{5} \mathrm{~L}_{6}$ do $\mathrm{Eu}^{3+}$. As bandas finas oriundas das transições intraconfiguracionais- $4 \mathrm{f}^{6}{ }^{7} \mathrm{~F}_{0} \rightarrow{ }^{5} \mathrm{G}_{6},{ }^{5} \mathrm{H}_{4}$ e ${ }^{5} \mathrm{~L}_{6}$ apresentam-se sobrepostas com as bandas largas dos ligantes. Deve-se informar que bandas finas com intensidade equivalente ${ }^{7} \mathrm{~F}_{0} \rightarrow{ }^{5} \mathrm{D}_{2}$ em $464 \mathrm{~nm}$ e com menores intensidades são observadas em torno de 532 e $578 \mathrm{~nm}$, as quais são atribuídas às transições ${ }^{7} \mathrm{~F}_{0} \rightarrow{ }^{5} \mathrm{D}_{1}$, e ${ }^{5} \mathrm{D}_{0}$ do íon $\mathrm{Eu}^{3+}$. De um modo geral, não é observado uma mudança significativa entre o espectro de excitação dos complexos hidratado ${ }^{[16]}$ e aqueles dos complexos contendo a 4-picNO (FIG. 5.6). As pequenas diferenças estão, provavelmente, associadas a pequenas mudanças nos níveis de energia do TTA, devido a distorções causadas pelos ligantes picolina, que é maior que a molécula de água. 
É observado que os espectros de excitação dos complexos apresentam bandas de maior intensidade na região de absorção do ligante (dicetonato) comparados com aquelas das transições ${ }^{7} \mathrm{~F}_{0} \rightarrow{ }^{5} \mathrm{D}_{\mathrm{J}}$ do íon $\mathrm{Eu}^{3+}$, evidenciando o grande potencial do ligante TTA de atuar como "antenas" no processo de transferência de energia Ligante-Eu ${ }^{3+}$.

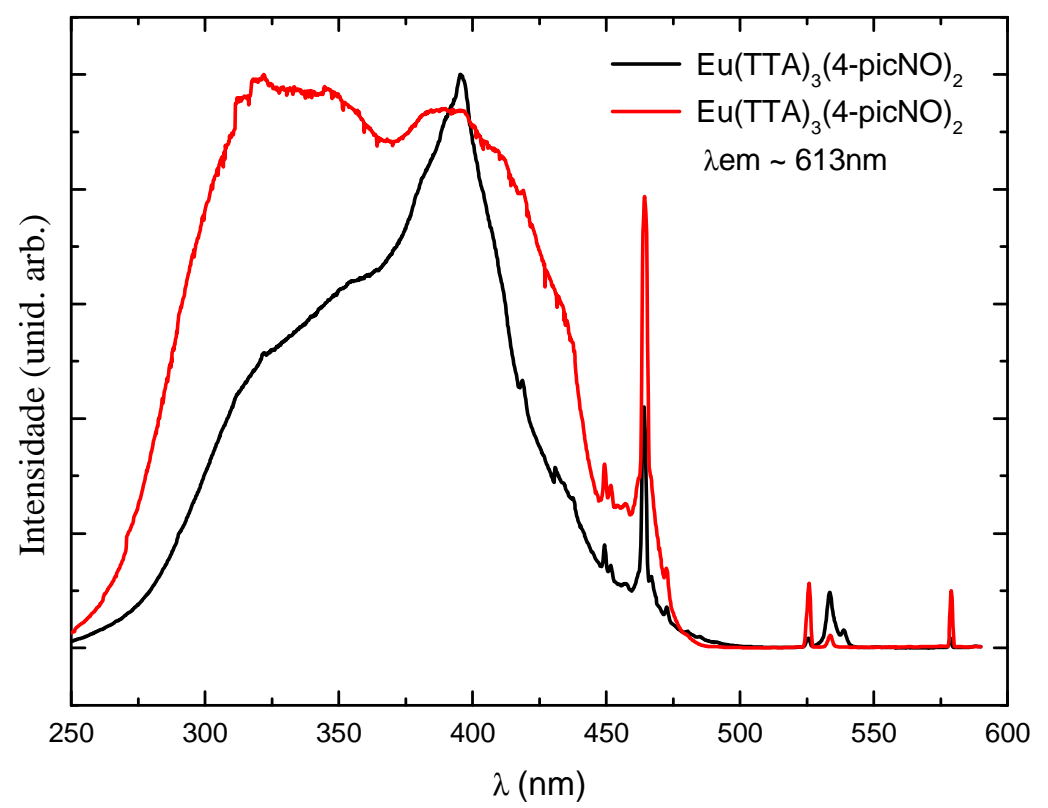

FIGURA 5.6. Espectro de excitação do complexo marcador $\left[\mathrm{Eu}(\mathrm{TTA})_{3}(4-\mathrm{picNO})_{2}\right] \mathrm{em}$ estado sólido, monitorando a emissão em aproximadamente $613 \mathrm{~nm}$. Em preto: temperatura ambiente e em vermelho: nitrogênio líquido.

\subsubsection{Espectros de Emissão}

Os espectros de emissão do complexo de európio com TTA ilustrados nas FIG. 5.7, foram registrados no intervalo de 420 a $700 \mathrm{~nm}$, a temperatura ambiente, com excitação monitorada em ( 330, 340,396 e $464 \mathrm{~nm})$. Estes espectros exibem bandas finas atribuídas às transições ${ }^{5} \mathrm{D}_{0} \rightarrow{ }^{7} \mathrm{~F}_{\mathrm{J}}$ (onde $\mathrm{J}=0,1,2,3,4$ ), sendo a transição hipersensível ${ }^{5} \mathrm{D}_{0} \rightarrow{ }^{7} \mathrm{~F}_{2}$ a mais intensa. A FIG. 5.7 (inserida) também apresentam bandas finas na região espectral de 500 a $570 \mathrm{~nm}$ oriundas das transições ${ }^{5} \mathrm{D}_{1} \rightarrow{ }^{7} \mathrm{~F}_{1}(\sim 538 \mathrm{~nm})$ e ${ }^{5} \mathrm{D}_{1} \rightarrow{ }^{7} \mathrm{~F}_{2}(\sim 560$ 
$\mathrm{nm}$ ), no entanto, essas bandas apresentam intensidade muito baixas, sendo somente observadas com ampliação da escala espectral.

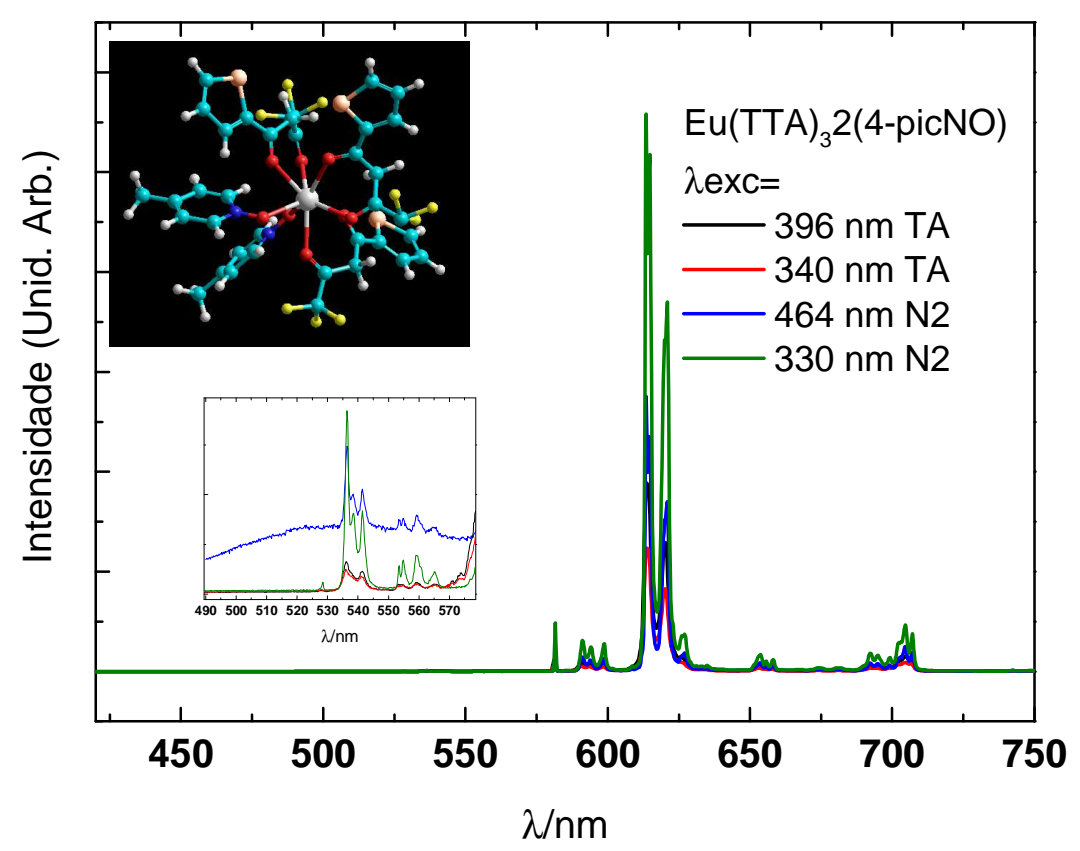

FIGURA 5.7. Espectro de emissão do complexo marcador $\left[\mathrm{Eu}(\mathrm{TTA})_{3}(4 \text {-picNO })_{2}\right]$ estado sólido, monitorando a emissão em 613nm.

É importante frisar que os espectros de emissão dos complexos de $\mathrm{Eu}^{3+}$ não apresentaram bandas largas oriundas da fosforescência do TTA no intervalo espectral de 420-600 nm. Esse resultado indica que os processos de transferência de energia do estado tripleto desses ligantes para os níveis excitados do európio são muito eficientes.

A presença da banda correspondente a transição ${ }^{5} \mathrm{D}_{0} \rightarrow{ }^{7} \mathrm{~F}_{0}$ nos espectros de emissão do complexo de TTA como um único pico $(\sim 581 \mathrm{~nm})$, indica a existência de somente um único sítio de simetria em torno do ambiente químico do íon $\mathrm{Eu}^{3+}$. Além disso, de acordo com a regra de seleção por simetria, essa transição só é permitida quando o $\mathrm{Eu}^{3+}$ está classificado em um dos grupos pontuais $\mathrm{C}_{\mathrm{nv}}, \mathrm{C}_{\mathrm{n}}$ ou $\mathrm{C}_{\mathrm{s}}{ }^{[14]}$. Adicionalmente, pode-se observar que as bandas correspondentes à transição ${ }^{5} \mathrm{D}_{0} \rightarrow{ }^{7} \mathrm{~F}_{2}$ estão desdobradas em no mínimo 3 componentes, indicando que os possíveis grupos pontais estão limitados àqueles de baixa simetria, $\mathrm{C}_{2 \mathrm{v}}, \mathrm{C}_{2}, \mathrm{C}_{1}$ ou $\mathrm{C}_{\mathrm{s}}$. 


\subsection{Ensaios qualitativos da metodologia para detecção de anemia falciforme utilizando tecnologia de testes rápidos de exames (point of care).}

Nesta parte do trabalho relatar-se-a os resultados dos estudos desenvolvidos para se obter um teste diagnóstico do tipo point of care com um alto desempenho e de forma muito simples, para a anemia falciforme (AF), que onde é possivel diferenciar de forma conclusiva entre as amostras de sangue a partir de indivíduos saudáveis, $\mathrm{Hb} \mathrm{AA}$, portadores do traço falciforme, $\mathrm{Hb} \mathrm{AS}$, e anemia falciforme $\mathrm{Hb} \mathrm{SS}$.

Tomou-se como base os testes convencionais para anemia falciforme e três parametros foram estudados: a concentração do tampão de fosfato, o agente redutor e o agente surfactante.

\subsubsection{Estudo da importância da concentração da solução tampão fosfato}

Sabe-se que a desoxi-Hb S é insolúvel em soluções tampão fosfato concentrada pois esta é uma metodologia que tem sido usada por bancos de sangue e laboratórios clínicos, então estudou-se a importância da concentração do tampão fosfato na reação de precipitação da $\mathrm{Hb}$ SS. Foram utilizadas 3 concentrações de tampão fosfato e a partir dos resultados obtidos pode-se observar que em todas as concentrações dos tampões (1,5 mol L ${ }^{-1} ; 1,8 \mathrm{~mol} \mathrm{~L}^{-1}$ e 2,3 $\left.\mathrm{mol} \mathrm{L}^{-1}\right)$ utilizados nesse trabalho os ensaios biológicos tiveram o mesmo desempenho, portanto não é necessário o uso de tampões em concentrações extremamente altas como o utilizado no kit comercial $\left(2,3 \mathrm{~mol} \mathrm{~L}^{-1}\right)^{[18]}$, sendo então um ponto positivo para o desenvolvimento de kits nacionais a mais baixo custo (FIG. 5.8). 


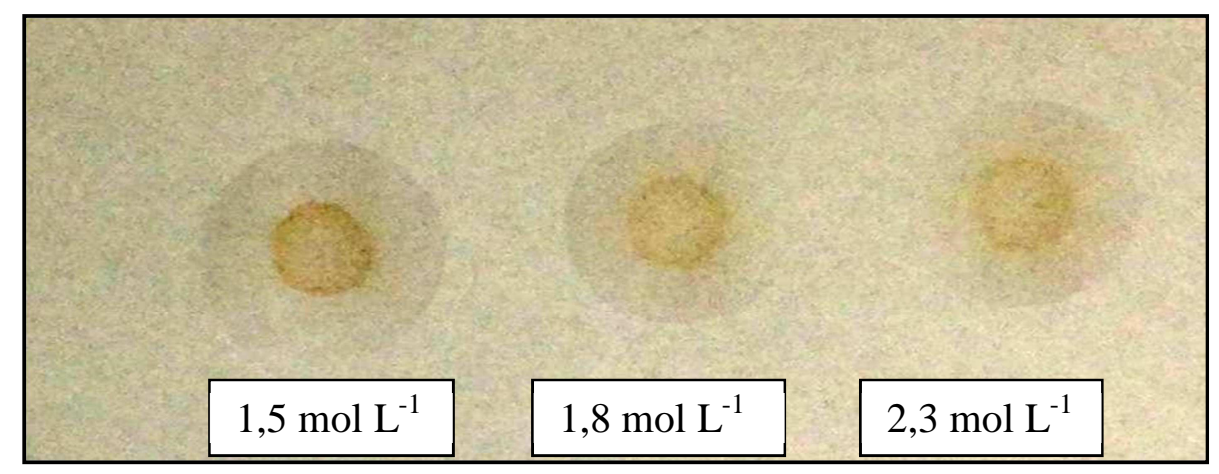

FIGURA 5.8. Imagem fotográfica dos spots mostrando o desenvolvimento dos halos obtidos utilizando-se as várias concentrações de tampão fosfato para Hb AS.

Como não havia informações sobre as concentrações dos reagentes sólidos no kit comercial foram testadas diversas concentrações a fim de se obter os melhores resultados. Com o intuito deste trabalho não apresentar dados repetitivos e extensos referentes aos resultados obtidos com as várias diluições testadas, foram escolhidos apenas os resultados de melhor comparação e os de fato efetivos como apresentados no decorrer deste capítulo.

\subsubsection{Estudo do agente surfactante}

A utilização de saponinas na metodologia convencional para a detecção de anemia falciforme como agente surfactante, está relacionada a lise das hemácias e é uma metodologia clássica. As saponinas são os glicosídeos saponosídicos e são compostos não nitrogenados que se dissolvem em água originando soluções afrógenas (espumantes), devido à sua ação tensoativa. Constituem um grupo heterogêneo muito comum em plantas medicinais classificado em glicosídeos saponosídicos do tipo esteróide e do tipo triterpênico. Possuem ainda a capacidade de emulsionar óleos e produzir hemólise. A atividade hemolítica deve-se à capacidade do glicosídeo de se combinar com as moléculas de colesterol presentes na membrana dos eritrócitos, perturbando o equilíbrio internoexterno e promovendo a ruptura da célula com consequente liberação da hemoglobina. 
Nesse trabalho, para se avaliar a eficácia dos agentes surfactantes foram utilizados três materiais com propriedades detergentes; a saponina que é um agente dispersante clássico, um detergente comercial Limpol® e o TWEEN 20.

As soluções contendo estes três surfactantes foram preparadas e as microgotas foram aplicadas no papel cromatográfico. Os resultados obtidos FIGs. 5.9 a 5.12. mostraram que os três surfactantes atuam de maneira eficiente fazendo a lise das hemácias para dispersão das hemoglobinas no meio aquoso.

Deste modo, mais especificamente os surfactantes saponina (SigmaAldrich) e o detergente comercial Limpol@ apresentaram bons resultados, diferenciando assim os tipos de hemoglobinas presentes em cada amostra como mostrado nas FIGs. 5.9 e 5.10. Quando comparados ao KIT comercial os resultados obtidos são $100 \%$ concordantes com este, o que torna a substituição da saponina pelo detergente comercial extremamente viável. Os halos corroboram com os dados pré-estabelecidos, onde as hemácias do tipo $\mathrm{Hb} \mathrm{AA}$ não formam o precipitado e as hemácias portadoras do traço falciforme precipitam formando uma região escura no centro do papel cromatográfico.

Em relação ao custo, a troca da saponina pelo detergente comercial proporcionaria uma economia relevante, pois um frasco de $100 \mathrm{~g}$ de saponina custa aproximadamente $\mathrm{R} \$ 400,00$ enquanto que um frasco do detergente comercial com $500 \mathrm{~mL}$ custa aproximadamente $\mathrm{R} \$ 1,20$ reduzindo os custos significativamente no valor final do produto. 
$\mathrm{Hb} \mathrm{AA}$

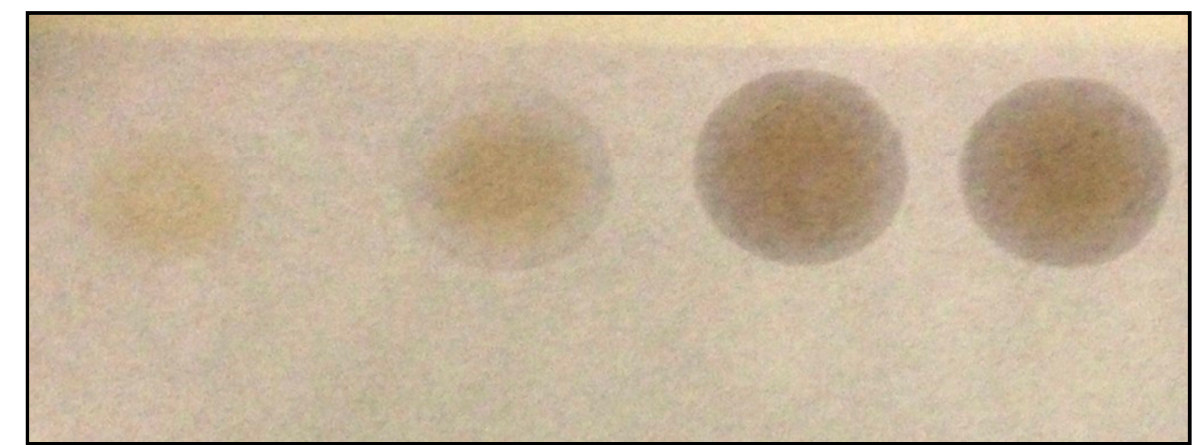

$\mathrm{Hb} \mathrm{AS}$

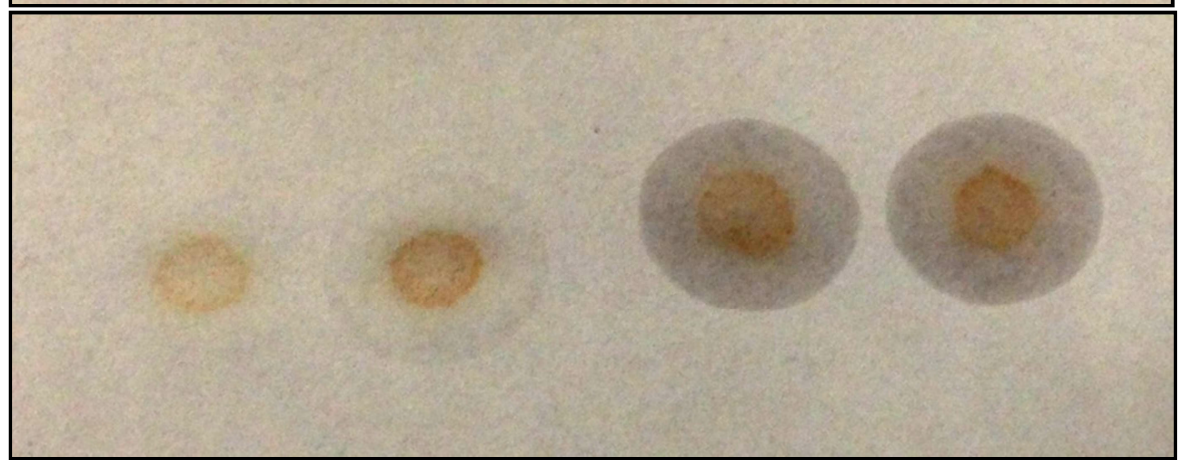

FIGURA 5.9. Imagem fotográfica, em quadruplicata, dos resultados obtidos utilizando saponina e hidrossulfito de sódio (1:2), 2,3 mol $\mathrm{L}^{-1}$. Resultados iguais para todas as concentrações dos tampões. Nos controles $\mathrm{Hb}$ AA e alvo $\mathrm{Hb}$ AS os dois últimos halos apresentaram-se mais escuros somente devido à umidade no momento da fotografia.

$\mathrm{Hb} \mathrm{AA}$

$\mathrm{Hb} \mathrm{AS}$

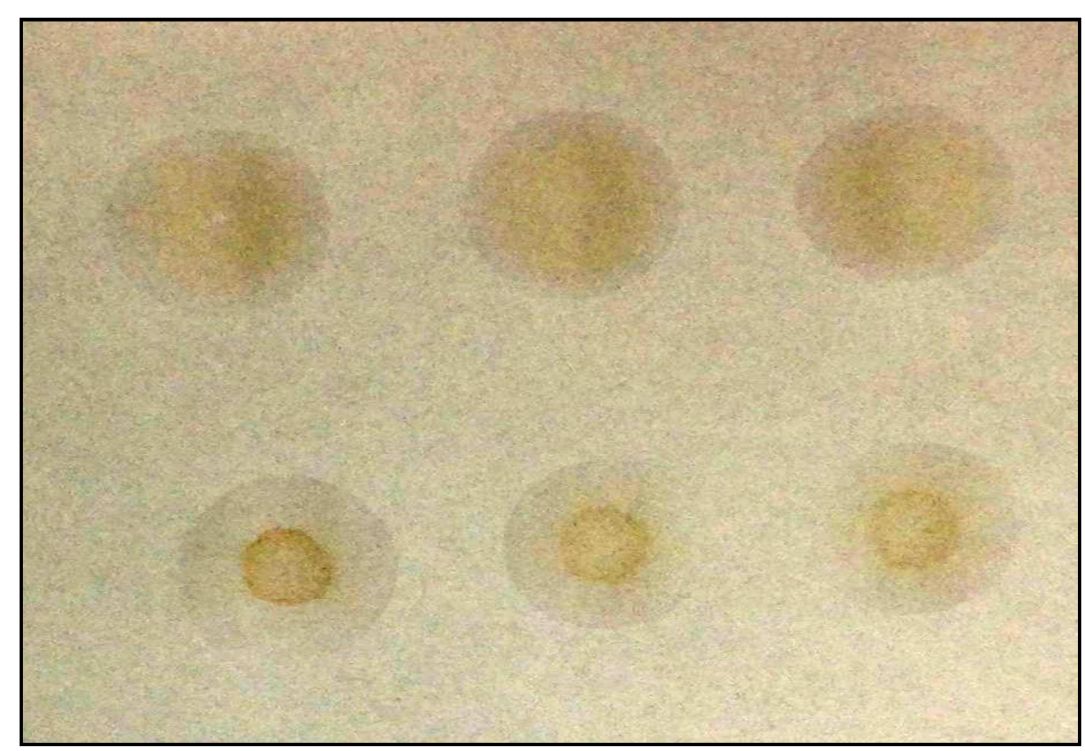

FIGURA 5.10. Imagem fotográfica, em triplicata, dos resultados obtidos utilizando detergente comercial Limpol® e hidrossulfito de sódio (1:2), 2,3 $\mathrm{mol} \mathrm{L}^{-1}$. Os controles $\mathrm{Hb}$ AA e alvo Hb AS apresentaram resultados iguais para todas as concentrações dos tampões. 
Na FIG. 5.11 foi observado que tanto o detergente comercial quanto o Tween 20 apresentaram a mesma formação de halos e tamanhos equivalentes. Desta forma podese concluir que eles são eficientes surfactantes para lise celular. O diâmetro médio dos halos formados foi de $0,75 \mathrm{~cm}$.

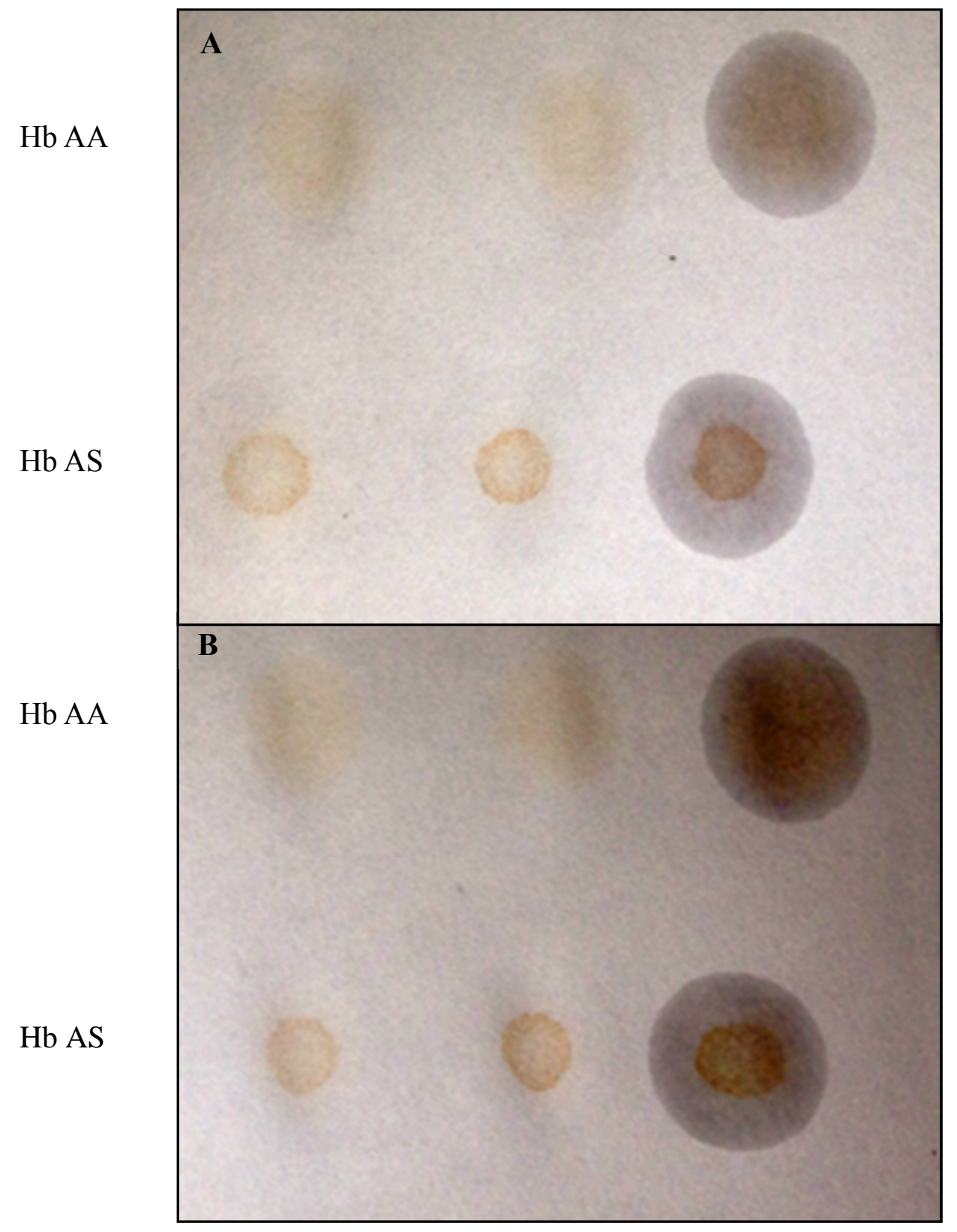

FIGURA 5.11. Imagem fotográfica, em triplicata, dos resultados obtidos utilizando detergente comercial Limpol® (A) e Tween 20 (B), 2,3 mol L-1 . Os controles Hb AA e alvo $\mathrm{Hb}$ AS apresentaram resultados iguais para todas as concentrações dos tampões 
citadas anteriormente. Os últimos halos apresentaram-se mais escuros somente devido à umidade no momento do registro da fotografia.

\subsubsection{Estudo dos agentes redutores}

A função do agente redutor no protocolo de detecção de anemia falciforme é acelerar a desoxigenação da hemoglobina $S$ como consequência da queda na tensão de oxigênio no meio. Neste método, adiciona-se uma gota de sangue em um produto químico que funciona como um agente redutor como, por exemplo, o hidrossulfito de sódio. Isso reduz rapidamente a oxi-hemoglobina para hemoglobina reduzida que é chamada de desoxi-hemoglonina. Neste trabalho usamos quatro substâncias químicas que atuaram como agente redutor: hidrossulfito de sódio, tiossulfato de sódio, ácido cítrico anidro e peróxido de hidrogênio.

Na FIG. 5.12 pode-se observar que os agentes redutores hidrossulfito de sódio e tiossulfato de sódio apresentaram os mesmos resultados para a diferenciação das hemoglobinas $\mathrm{Hb}$ AA e Hb AS. Há a formação dos halos para a hemoglobina $\mathrm{Hb}$ AS mais escurecidos nas bordas do que no centro e medindo cerca de $0,75 \mathrm{~cm}$ de diâmetro. Em relação ao custo, a troca do hidrossulfito de sódio por tiossulfato de sódio leva também a uma economia relevante na composição final do kit diagnóstico. O hidrossulfito de sódio custa aproximadamente três vezes o valor do tiossulfato de sódio. 


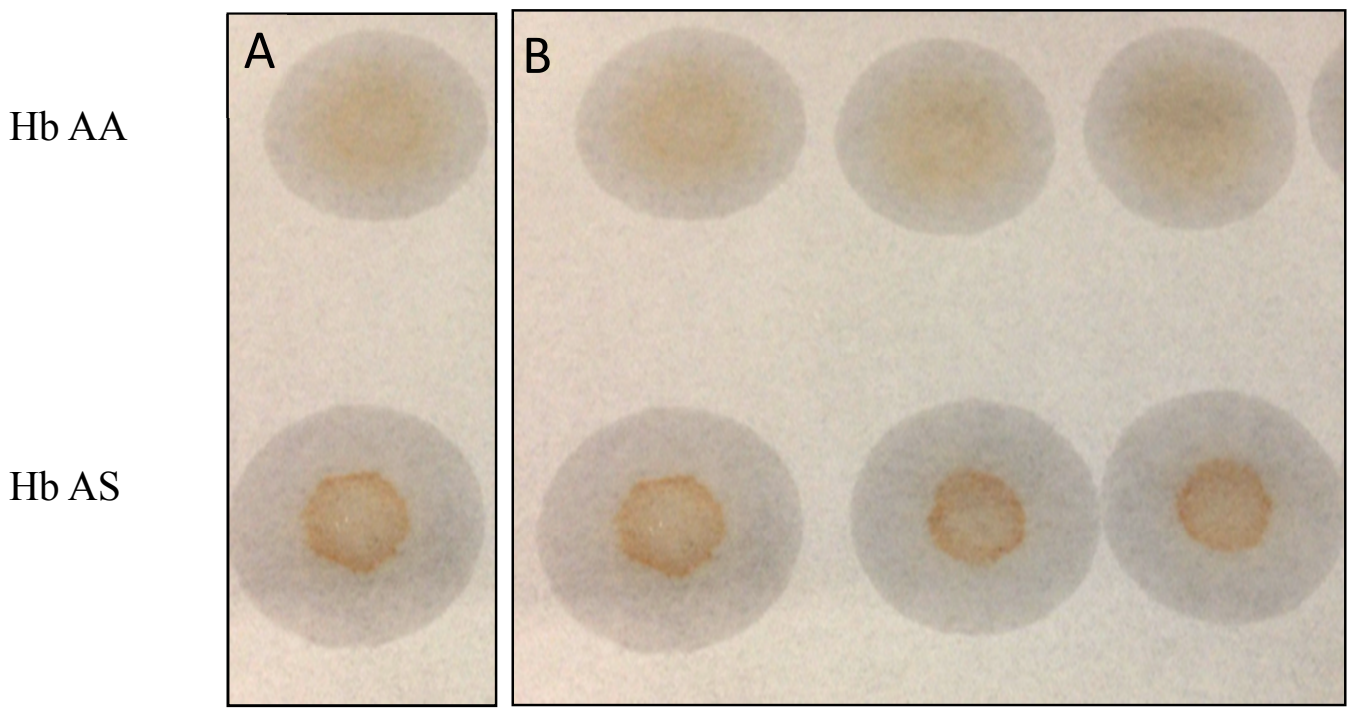

FIGURA 5.12. Imagem fotográfica dos resultados obtidos através da substituição do hidrossulfito de sódio (A) por tiossulfato de sódio (B), tanto com detergente comercial Limpol ${ }^{\circledR}$ quanto saponina, $2,3 \mathrm{~mol} \mathrm{~L}^{-1}$. Os controles $\mathrm{Hb}$ AA e alvo $\mathrm{Hb}$ AS apresentaram resultados iguais para todas as concentrações dos tampões.

Os resultados acima mostraram uma coerência com as análises controles feitas a partir de um kit comercializado internacionalmente.

Vale salientar que nos resultados para $\mathrm{Hb}$ AA a maioria dos halos apresentou um contorno um pouco mais escuro nos seus centros, mas tal ocorrência foi devido à deposição dos detritos celulares produzidos pela lise das hemácias, o que acontece normalmente sem nenhuma interferência nos resultados.

Já na FIG. 5.13 pode-se observar que os ensaios para tentativa de substituição do hidrossulfito de sódio por ácido cítrico anidro e peróxido de hidrogênio apresentaram resultados falsos positivos. Os falsos positivos foram identificados para o grupo controle ( $\mathrm{Hb} \mathrm{AA}$ ) que teve comportamento similar ao grupo alvo ( $\mathrm{Hb} \mathrm{AS}$ ), ou seja, resultados de padrões $\mathrm{Hb}$ AA apresentaram as mesmas formações de halos como no grupo de padrões com o traço falciforme $\mathrm{Hb}$ AS. Nesses resultados observou-se a hemoglobina A aglomerada no centro do halo formado no papel, indicando a falsa presença da desoxi-Hb 
S. Portanto, o ácido cítrico não atuou como um agente redutor eficiente, alterando bioquimicamente a estrutura da hemoglobina normal ( $\mathrm{Hb} \mathrm{AA})$.

$\mathrm{Hb} \mathrm{AA}$

$\mathrm{Hb} \mathrm{AS}$

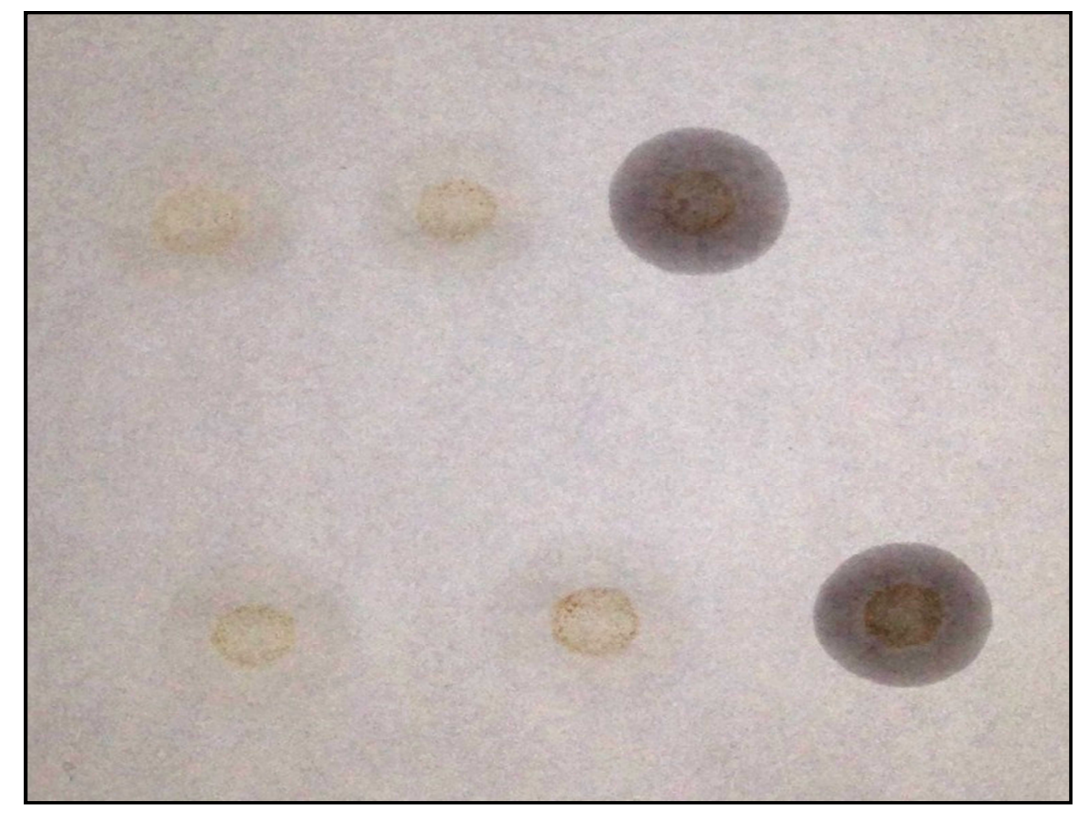

FIGURA 5.13. Imagem fotográfica, em triplicata, dos resultados obtidos por meio da substituição do hidrossulfito de sódio por ácido cítrico anidro e peróxido de hidrogênio, tanto com detergente comercial Limpol® ou saponina, 2,3 $\mathrm{mol} \mathrm{L}^{-1}$. Os controles $\mathrm{Hb}$ AA e alvo $\mathrm{Hb}$ AS apresentaram resultados iguais para todas as concentrações dos tampões. Os últimos halos apresentaram-se mais escuros somente devido à umidade no momento da fotografia.

Finalizando, foram identificadas grandes diferenças visuais entre a forma dos spots dos padrões de sangue, das amostras de sangue sem anemia falciforme, com anemia falciforme e das amostras com o traço da doença. A natureza química das diferentes hemoglobinas foi o que determinou a desoxigenação e a polimerização da $\mathrm{Hb} \mathrm{S}$. Esta polimerização foi observada, a olho nu, como círculos quase uniformes nos centros onde houve a formação dos halos que continham sangue com traço da anemia falciforme $(\mathrm{Hb}$ AS) e círculos escuros e uniformes que continham sangue de pacientes com anemia falciforme (Hb SS). 
Portanto, com base nos resultados obtidos criou-se um kit brasileiro de identificação de hemoglobinas usando o detergente comercial e o tiossulfato de sódio que são reagentes mais baratos e apresentam a mesma eficiência que os reagentes clássicos utilizados, reduzindo assim o custo quando comparado com o método internacional.

Segue comparativo final do kit desenvolvido com o kit comercial, FIG. 5.14.

$\mathrm{Hb} \mathrm{AA}$

$\mathrm{Hb} \mathrm{AS}$

$\mathrm{Hb} \mathrm{SS}$

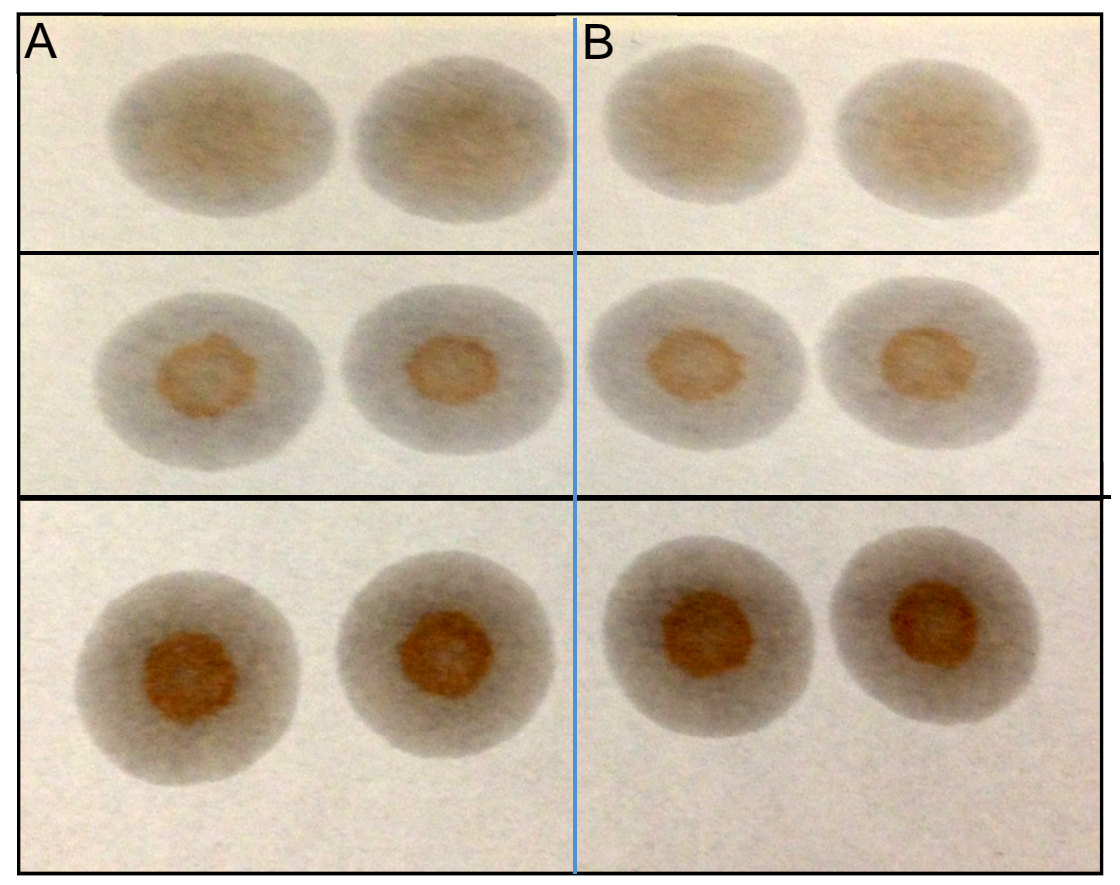

FIGURA 5.14. Comparação dos resultados do kit comercial (A) com o método desenvolvido neste trabalho (B), 2,3 mol L $\mathrm{L}^{-1}$. Controle $\mathrm{Hb}$ AA e alvos $\mathrm{Hb} \mathrm{AS}$ e $\mathrm{Hb} \mathrm{SS}$. Resultados iguais para todas as concentrações de tampão citadas anteriormente.

Segundo as especificações do kit comercial, após 45 dias, as soluções perdem sua sensibilidade, podendo provocar resultados falso-positivos e/ou falso-negativos como também podem adquirir contaminação por fungos e bactérias. Foi observado que os tampões autoclavados, não autoclavados e aqueles com e sem 2-cloroacetamida apresentaram a mesma sensibilidade não havendo contaminação visível, das soluções no 
mesmo intervalo, ou seja, os testes não necessitam de soluções tampão autoclavadas nem a utilização de conservantes durante 45 dias.

\subsection{Marcação das células vermelhas do sangue com complexos de terras raras}

Nas últimas décadas testemunhou-se o surgimento e o rápido desenvolvimento da nanociência e da nanotecnologia, incluindo nanoquímica, nanofísica, nanomedicina e nanobiomateriais, que permite a exploração de técnicas bioanalíticas fáceis, baratas e sensíveis, e que empregam sondas biológicas nanoestruturadas ${ }^{[19-21]}$.

Até o momento, os tipos mais comuns de sondas biológicas luminescentes são os corantes orgânicos, os quelatos de lantanídeos e os pontos quânticos de semicondutores (QDs) ${ }^{[22-27]}$. No entanto, a utilização destas sondas biológicas convencionais na biodetecção apresentam suas desvantagens como, por exemplo, autofluorescência de fundo alta e um envelhecimento devido a radiação ultravioleta, considerável, alem de bandas de emissão e excitação largas, baixa estabilidade fotoquímica, tempo de vida de luminescência curto e toxicidade a longo prazo ${ }^{[28]}$.

As técnicas de bioensaio baseados em $\operatorname{Ln}^{3+}$ são utilizadas em uma variedade de ensaios biológicos sensíveis, em que os analitos padrões tais como avidin-biotina, IgG, antígeno-anticorpo foram mais freqüentemente testado ${ }^{[29-31]}$.

Posteriormente, com base em nanomarcadores dopados com lantanídeos e atraves de estratégias desenvolvidas para bioconjugação para detecção de analitos padrões, alguns sistemas práticos para biosensoriamento foram estabelecidos para ensaios de ácidos nucleicos e íons, que desempenham papéis fundamentais em funções biológicas ${ }^{[32,33]}$. Finalmente, o desenvolvimento de novas técnicas de detecção por biomarcadores destinase a agentes terapêuticos e de diagnóstico precoce de doenças. As propriedades ópticas das sondas dopadas com $\mathrm{Ln}^{3+}$ são únicas e combinadas com os métodos de ensaio já bem estabelecidos permitirão a concepção de plataformas técnológicas de biomarcadores altamente sensíveis ${ }^{[34,35]}$. 
As propriedades fotofísicas e eletrônicas diferenciadas dos lantanídeos, juntamente com a ausência destes elementos nos sistemas vivos, têm estimulado o desenvolvimento de métodos que exploram estas propriedades para proporcionar uma nova visão sobre a estrutura, função e dinâmica de proteínas ${ }^{[36]}$. Para uma determinada proteína a similaridade entre os íons lantanídeos trivalentes e o cálcio divalente em termos de raio iônico e oxofilicidade torna possível a substituição direta do cálcio ligado a proteína, proporcionando viabilidade no que se refere à espectroscopia, para se estudar estruturas e dinâmica ${ }^{[37-39]}$.

Neste trabalho um complexo de lantanídeo foi ligado as hemoglobinas para melhorar a sinalização das mesmas, no kit desenvolvido. Na FIG. 5.15 apresenta-se um esquema de uma hemácia conjugada com um biomarcador de európio.

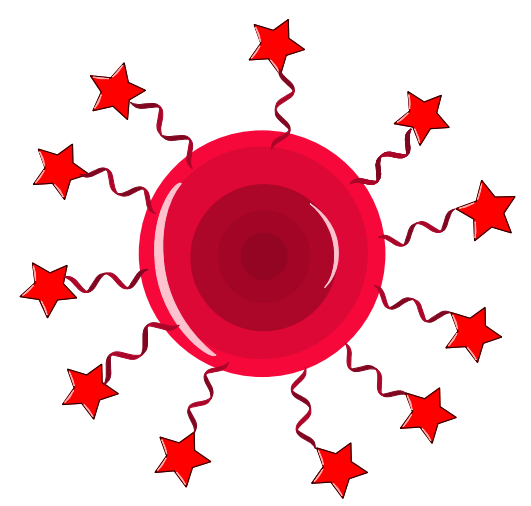

FIGURA 5.15. Esquema da marcação da célula da hemácia por um marcador de európio.

Neste trabalho a primeira avaliação foi quanto ao marcador $\left[\mathrm{Eu}(\mathrm{TTA})_{3}(4-\mathrm{picNO})_{2}\right]$ em solução aquosa, sendo então explorados os espectros de excitação e emissão do complexo no estado sólido e em solução. Observou-se tanto no espectro de excitação quanto no de emissão um mesmo perfil das bandas sendo que no espectro de excitação as transições referentes à configuração do íon európio perdem intensidade e não aparecem no conjunto espectral (FIG. 5.16). Tanto o espectro de excitação quanto o de emissão observa-se um deslocamento nos espectros em solução para 
região de mais alta energia. Os espectros de excitação são dominados pela banda larga do ligante na região de 250-470 nm que estão convoluídas com as transições 4f-4f.

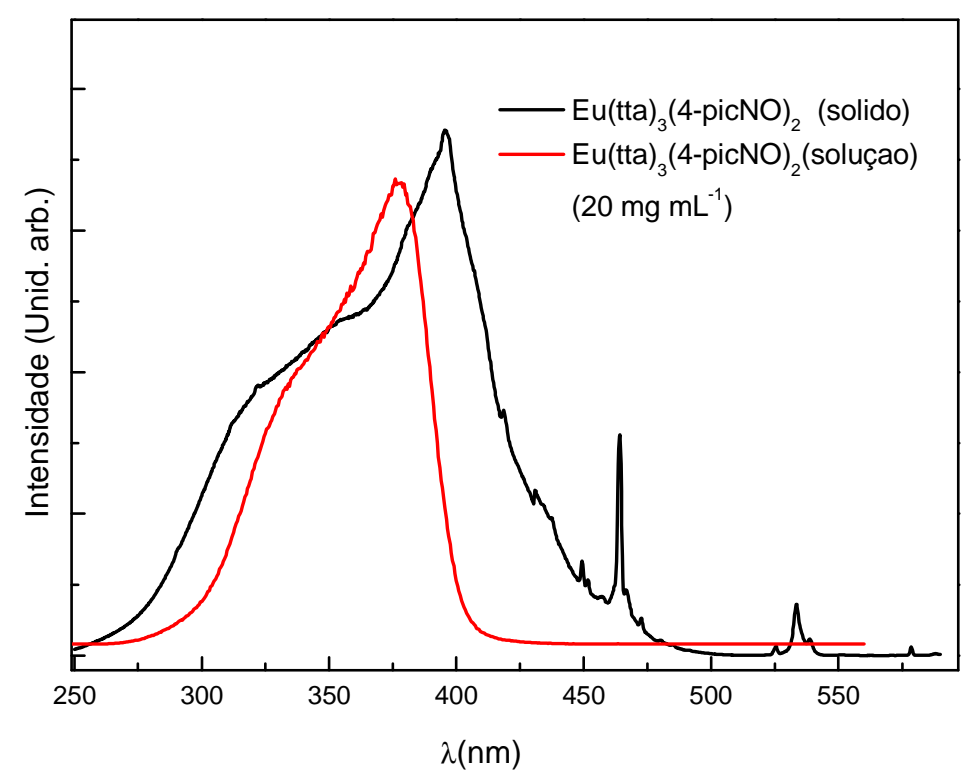

FIGURA 5.16. Espectro de excitação do marcador $\left[\mathrm{Eu}(\mathrm{TTA})_{3}(4-\text { picNO })_{2}\right.$ ] no estado sólido e em solução tampão a temperatura ambiente.

Os espectros de emissão (FIG. 5.17) foram registrados com a excitação monitorados na banda do ligante onde a intensidade espectral foi maior em relação a excitação no íon. Os espectros mostram as bandas oriundas das transições intraconfiguracionais ${ }^{5} \mathrm{D}_{0} \rightarrow{ }^{7} \mathrm{~F}_{\mathrm{J}}$ (onde $\mathrm{J}=0,1,2,3,4,5$ e 6), características do íon európio. O espectro em solução apresenta-se também deslocado para região de maior energia. 


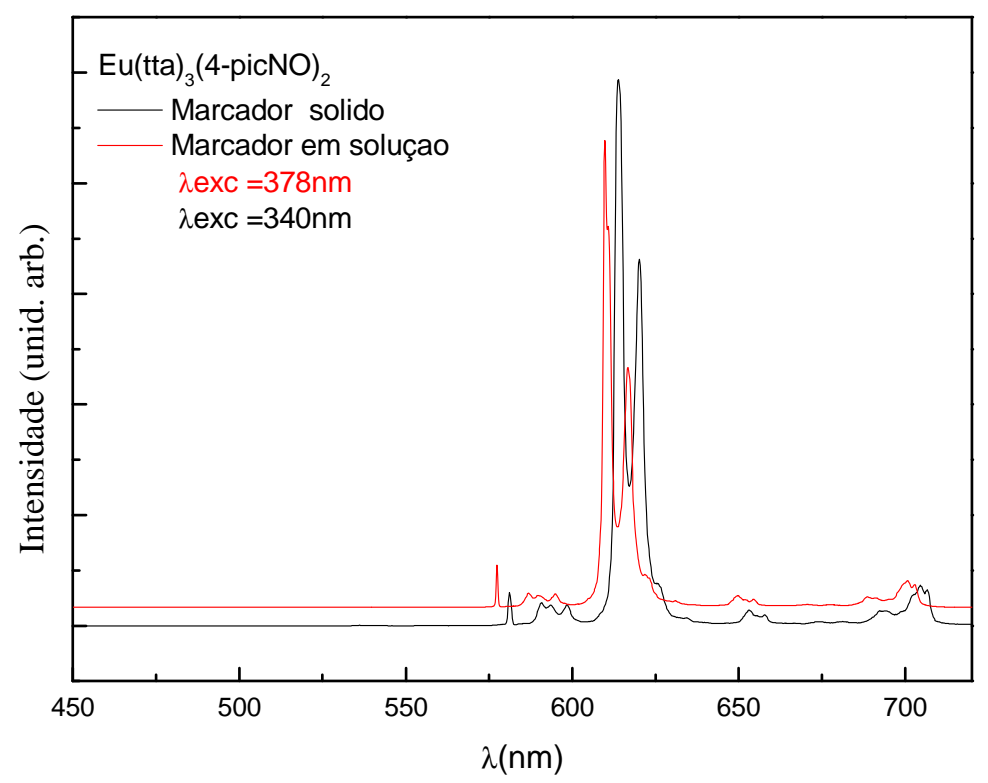

FIGURA 5.17. Espectro de emissão do marcador [Eu(TTA $\left.)_{3}(4-p i c N O)_{2}\right]$ no estado sólido e em solução aquosa à temperatura ambiente

Para se avaliar a conjugação do marcador com a hemoglobina fez-se uma comparação entre os espectros de excitação e emissão do marcador e do marcador ligado a hemoglobina Hb AS, FIGs. 5.18 e 5.19, respectivamente. Vale salientar aqui que a solução do marcador-hemoglobina AS está dispersa na solução final do kit desenvolvido pelo nosso grupo.

O espectro de excitação do marcador conjugado à hemoglobina mostra a banda de excitação do ligante mais alargada que no marcador sozinho e as bandas referentes às transições f-f do íon európio um pouco mais intensa. Já no espectro de emissão, embora numa avaliação rápida não seja possível visualizar, quando se amplia regiões do espectro de menor intensidade, ou se alarga o espectro na região da ${ }^{5} \mathrm{D}_{0} \rightarrow{ }^{7} \mathrm{~F}_{2}$ estas diferenças são perceptíveis.

A presença da transição ${ }^{5} \mathrm{D}_{0} \rightarrow{ }^{7} \mathrm{~F}_{0}$ é atribuída ao efeito de mistura dos $\mathrm{J}$ 's através da componente de paridade par do campo cristalino. Segundo este efeito participam da composição do estado $\left|{ }^{7} \mathrm{~F}_{0}\right\rangle$ os $\left|{ }^{7} \mathrm{~F}_{2}\right\rangle,\left|{ }^{7} \mathrm{~F}_{4}\right\rangle$, e $\left|{ }^{7} \mathrm{~F}_{6}\right\rangle$, sendo que a maior contribuição é 
dada pelo $\left|{ }^{7} \mathrm{~F}_{2}\right\rangle$. Assim, são assumidas as seguintes condições: a mistura dos J's somente ocorre dentro do ${ }^{7} \mathrm{~F}_{\mathrm{J}}$ e apenas o termo com $\mathrm{J}=2$ é considerado. Desta forma o $\left|{ }^{7} \mathrm{~F}_{0}\right\rangle$ passa a ser representado pela equação 5.1:

$$
\left.\left|{ }^{7} F_{0}\right\rangle\left|=C_{00}\right|{ }^{7} F_{00}\right\rangle+\sum_{M_{J}} C_{2} M_{J}\left|{ }^{7} F_{2} M_{J}\right\rangle
$$

A dependência entre a transição ${ }^{5} \mathrm{D}_{0} \rightarrow{ }^{7} \mathrm{~F}_{0}$ e a transição ${ }^{5} \mathrm{D}_{0} \rightarrow{ }^{7} \mathrm{~F}_{2}$ sugere que a primeira pode ser considerada como pseudo-hipersensível. Da relação entre estas transições define-se o parâmetro $\mathrm{R}_{02}$ que pode ser usado na análise da intensidade da transição ${ }^{5} \mathrm{D}_{0} \rightarrow{ }^{7} \mathrm{~F}_{0}$ e na avaliação do efeito de mistura dos J's (Equação 5.2).

$$
R_{02}=\frac{I(0,0)}{I(0,2)}=\frac{S(0,0)}{S(0,2)}=\frac{\sigma_{0,0} A(0,0)}{\sigma_{0,2} A(0,2)} \cong \frac{A(0,0)}{A(0,2)}
$$

Onde $\mathrm{S}$ é a área sob a curva da transição correspondente e $\sigma$ é a energia média da transição.

Neste trabalho a transição ${ }^{5} \mathrm{D}_{0} \rightarrow{ }^{7} \mathrm{~F}_{0}$ não se desloca e permanece mais intensa do que a transição ${ }^{5} \mathrm{D}_{0} \rightarrow{ }^{7} \mathrm{~F}_{1}$ em ambos os espectros corroborando com a afirmação que o efeito de mistura dos J's é efetivo nestes sistemas.

As bandas com baricentro em $~ 593 \mathrm{~nm}$ são atribuídas à transição ${ }^{5} \mathrm{D}_{0} \rightarrow{ }^{7} \mathrm{~F}_{1}$, que é permitida por dipolo magnético e sab-se que estas bandas não se altera com a modificação no sítio de simetria (a probabilidade de ocorrer transição ${ }^{5} \mathrm{D}_{0} \rightarrow{ }^{7} \mathrm{~F}_{1}$ não é afetada pela simetria porque é permitida por regra de seleção de paridade). Na comparação do marcador com o sistema marcador-Hb AS claramente pode-se observar que esta transição para o sistema conjugado não obedece a regra de seleção de paridade e apresentando 6 bandas quando o máximo (de $2 \mathrm{~J}+1)$ seria 3 e que nos levou a concluir que um segundo sítio de simetria foi formado quando da conjugação do marcador com a hemoglobina (FIG. 5.19). 
A banda mais proeminente no espectro de emissão centrada em $\sim 610 \mathrm{~nm}$ e responsável pela emissão no vermelho é atribuída a transição permitida por dipolo elétrico ${ }^{5} \mathrm{D}_{0} \rightarrow{ }^{7} \mathrm{~F}_{2}$. Esta banda geralmente é muito mais intensa que a referente à transição ${ }^{5} \mathrm{D}_{0} \rightarrow{ }^{7} \mathrm{~F}_{1}$ quando a simetria em redor do íon $\mathrm{Eu}^{3+}$ não possui centro de inversão. A transição ${ }^{5} \mathrm{D}_{0} \rightarrow{ }^{7} \mathrm{~F}_{2}$ é muito sensível a pequenas alterações no ambiente químico dos íons $\mathrm{Eu}^{3+}$. A intensidade desta transição de dipolo elétrico é significativamente afetada pelo grau de simetria do ambiente ao redor dos íons $\mathrm{Eu}^{3}$. Quando compara-se na FIG. 5.21 as duas transições ${ }^{5} \mathrm{D}_{0} \rightarrow{ }^{7} \mathrm{~F}_{2}$ pode se observar um deslocamento nas intensidades máximas dos picos e o desaparecimento de uma das bandas para o espectro conjugado com a hemoglobina, corroborando com a ideia de formação de mais de um sítio de simetria ao redor do $\mathrm{Eu}^{3+}$.

A transição ${ }^{5} \mathrm{D}_{0} \rightarrow{ }^{7} \mathrm{~F}_{4}$ centrada em $\sim 700 \mathrm{~nm}$ está relacionada aos parâmetros de intensidade de quarta ordem. Suas intensidades são menos afetadas por regra de seleção de simetria do que as transições ${ }^{5} \mathrm{D}_{0} \rightarrow{ }^{7} \mathrm{~F}_{2}$.

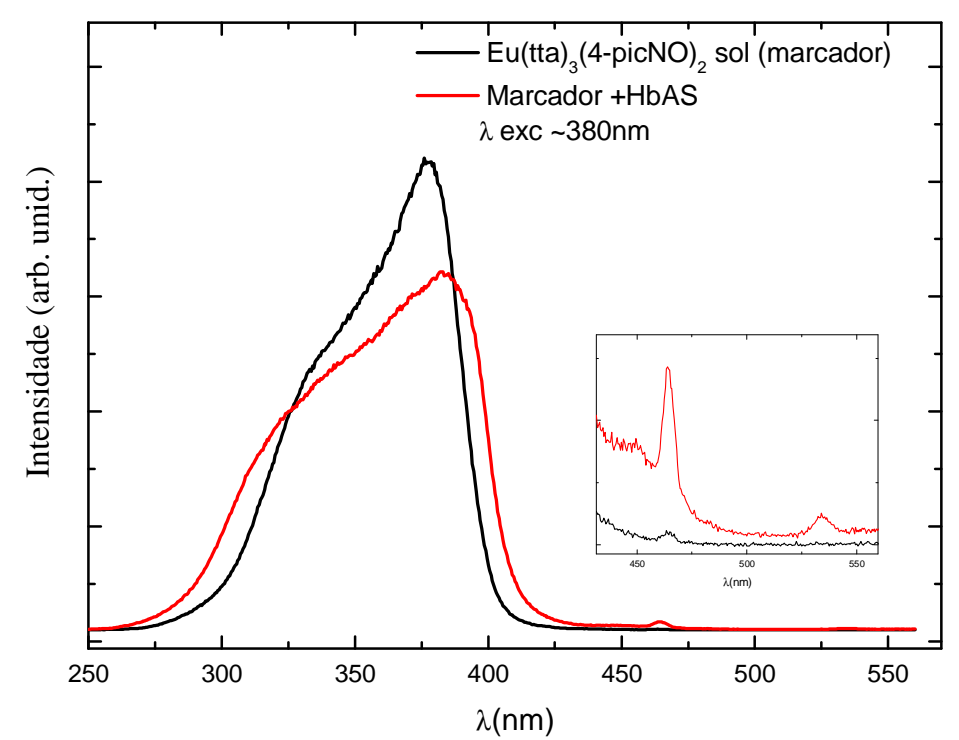

FIGURA 5.18. Espectro de excitação do marcador $\left[\mathrm{Eu}(\mathrm{TTA})_{3}(4-\text { picNO })_{2}\right]$ e do marcador conjugado com a Hb AS em solução aquosa à temperatura ambiente. 


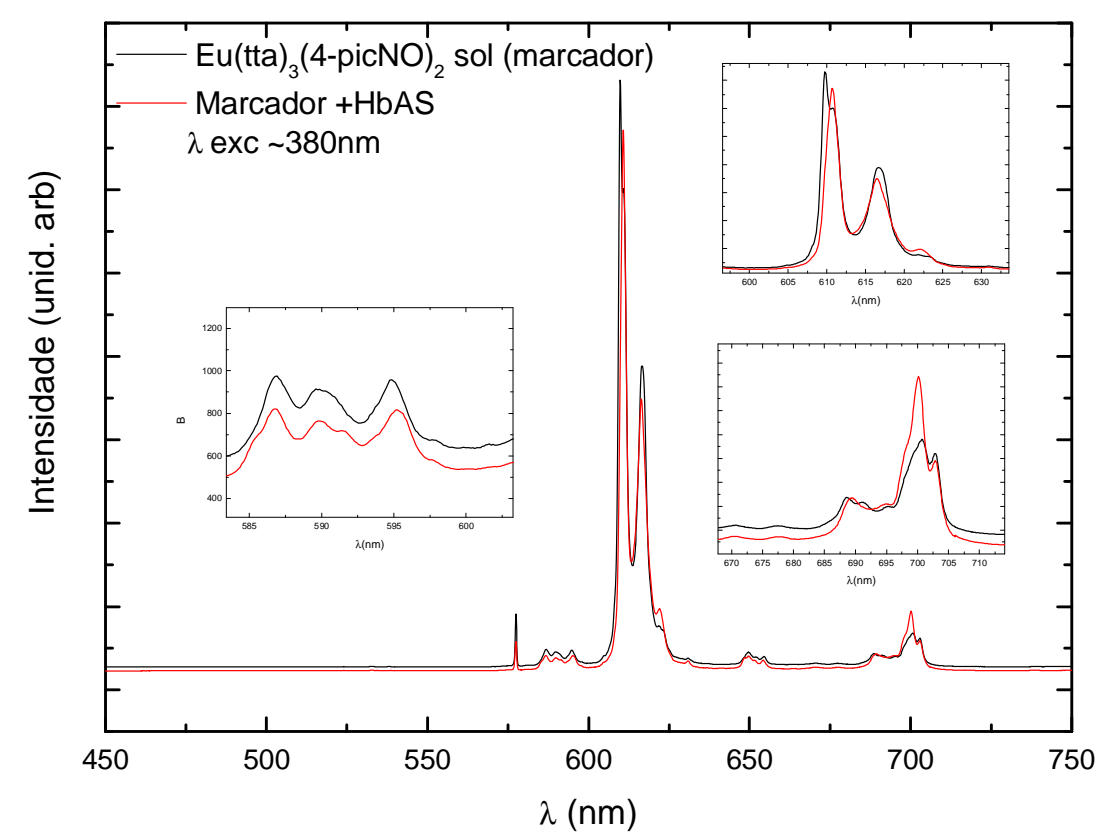

FIGURA 5.19. Espectro de emissão do marcador $\left[\mathrm{Eu}(\mathrm{TTA})_{3}(4 \text {-picNO })_{2}\right.$ ] e do marcador conjugado com a Hb AS em solução aquosa à temperatura ambiente.

Para se fazer uma avaliação da conjugação de todas as hemoglobinas com o marcador foram registrados todos os espectros de excitação e emissão destes materiais para avaliação. FIG. 5.20 e 5.21 .

Um comportamento semelhante entre as hemoglobinas foi observado e quando comparados ao espectro de excitação do marcador pode-se confirmar que as bandas dos sistemas contendo as hemoglobinas atribuídas a absorção do ligante estão mais alargadas. 


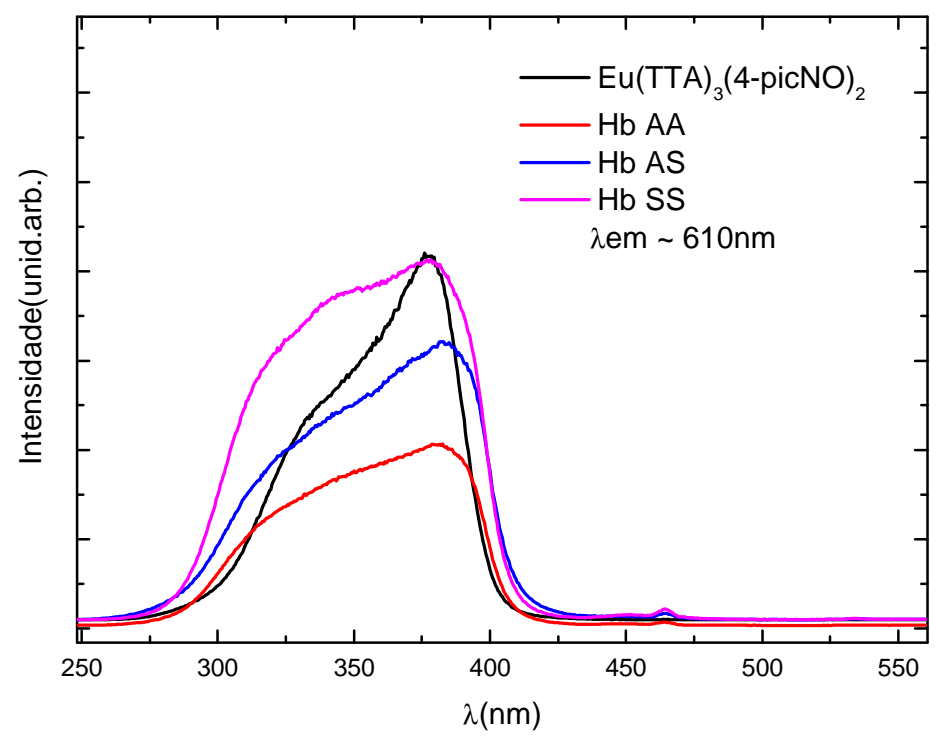

FIGURA 5.20. Espectro de excitação do marcador $\left[\mathrm{Eu}(\mathrm{TTA})_{3}(4 \text {-picNO })_{2}\right]$ e do marcador conjugado com as hemoglobinas $\mathrm{HbAS}$, HbSS e HbAA em solução aquosa à temperatura ambiente.

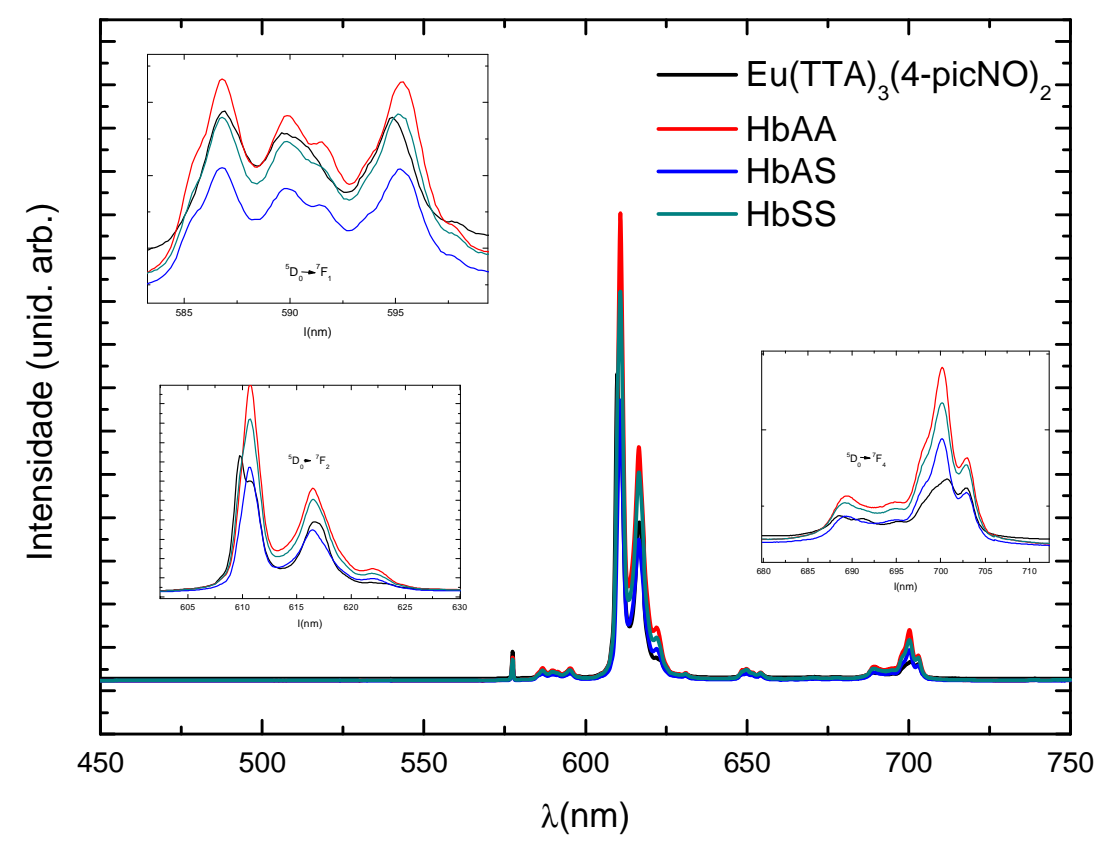

FIGURA 5.21. Espectro de emissão do marcador [Eu(TTA $)_{3}(4-p i c N O)_{2}$ ] e do marcador conjugado com as hemoglobinas $\mathrm{Hb} \mathrm{AS}, \mathrm{Hb}$ SS e $\mathrm{Hb} \mathrm{AA}$ em solução aquosa à temperatura ambiente. 
Com o intuito de se obter mais informações sobre a conjugação da hemoglobina ao marcador foi possível determinar os parâmetros de intensidade a partir dos espectros de emissão.

Os parâmetros de intensidade experimentais $\Omega_{\lambda}(\lambda=2,4$ e 6), também chamados de parâmteros de Judd-Ofelt, e possuem contribuições dos mecanismos de dipolo elétrico e acoplamento dinâmico ${ }^{[40,41]}$. Estes parâmetros são determinados experimentalmente por meio das intensidades das respectivas transições ${ }^{5} \mathrm{D}_{0} \rightarrow{ }^{7} \mathrm{~F}_{\mathrm{J}}$ do íon $\mathrm{Eu}^{3+}[42]$

Os coeficientes $\mathrm{A}_{0 \rightarrow \mathrm{J}}$ apresentam uma relação direta com os elementos de matriz reduzidos, consequentemente, os parâmetros de intensidade $\Omega_{2}, \Omega_{4}$ e $\Omega_{6}$ também podem ser determinados a partir dos respectivos valores de coeficientes de emissão espontânea (A) de acordo com a equação 5.3:

$$
\Omega_{\lambda}=\frac{4 \mathrm{e}^{2} \omega^{3} \mathrm{~A}_{0 \rightarrow \lambda}}{3 \hbar \mathrm{c}^{3} \chi\left\langle{ }^{7} \mathrm{~F}_{\lambda}\left\|\mathrm{U}^{(\lambda)}\right\|^{5} \mathrm{D}_{0}\right\rangle^{2}}
$$

Neste trabalho, não será considerado o valor de $\Omega_{6}$, uma vez que a transição ${ }^{5} \mathrm{D}_{0} \rightarrow{ }^{7} \mathrm{~F}_{6}$ não foi registrada.

Como pode ser observado, os valores do parâmetro de intensidade $\Omega_{2}$ são menores do que para os outros complexos estudados pelo grupo ou para matrizes inorgânicas ${ }^{[43]}$. Esses dados indicam que o íon $\mathrm{Eu}^{3+}$ nessa matriz encontra-se em um ambiente químico menos polarizável.

Os valores de $\Omega_{2}$ apresentam-se maiores do que os de $\Omega_{4}$, mostrando que as interações de segunda ordem são mais importantes no sistema utilizados e refletem as mudanças efetuadas pela presença de hemoglobinas conjugadas com o complexo. Na TAB. 5.1 pode-se ver estes resultados. 
TABELA 5.1. Parâmetros de intensidade $\left(\Omega_{\lambda}\right)$, R02 e R04 determinado em 298 K para o marcador e para os sistemas com as proteínas.

\begin{tabular}{lcccc}
\hline \multicolumn{1}{c}{ Sistemas } & $\begin{array}{c}\boldsymbol{\Omega}_{\mathbf{2}} \\
\left(\mathbf{1 0}^{-\mathbf{2 0}} \mathbf{c m}^{\mathbf{2}}\right)\end{array}$ & $\begin{array}{c}\mathbf{\Omega}_{\mathbf{4}} \\
\left(\mathbf{1 0}^{-\mathbf{2 0}} \mathbf{c m}^{\mathbf{2}}\right)\end{array}$ & $\mathbf{R}_{\mathbf{0 2}}$ & $\mathbf{R}_{\mathbf{0 4}}$ \\
\hline$\left[\mathrm{Eu}(\mathrm{TTA})_{3}(4-\text { picNO })_{2}\right]$ sol & 11,2 & 7,6 & 0,028 & 0,100 \\
{$\left[\mathrm{Eu}(\mathrm{TTA})_{3}(4-\text { picNO })_{2}\right]+\mathrm{HbAA}$} & 19,1 & 9,6 & 0,017 & 0,080 \\
{$\left[\mathrm{Eu}(\mathrm{TTA})_{3}(4-\mathrm{picNO})_{2}\right]+\mathrm{HbAS}$} & 16,7 & 9,3 & 0,019 & 0,084 \\
{$\left[\mathrm{Eu}(\mathrm{TTA})_{3}(4-\text { picNO })_{2}\right]+\mathrm{HbSS}$} & 14,9 & 9,0 & 0,020 & 0,078 \\
\hline
\end{tabular}

A TAB. 5.1 apresenta de forma comparativa os valores dos parâmetros $\mathrm{R}_{02} \mathrm{e}$ $\mathrm{R}_{04}$ para os compostos de $\mathrm{Eu}^{3+}$, o qual é definido como a razão entre a intensidade da transição ${ }^{5} \mathrm{D}_{0} \rightarrow{ }^{7} \mathrm{~F}_{0}$ pela intensidade da transição hipersensível ${ }^{5} \mathrm{D}_{0} \rightarrow{ }^{7} \mathrm{~F}_{2}$ e ${ }^{5} \mathrm{D}_{0} \rightarrow{ }^{7} \mathrm{~F}_{4}$, respectivamente. Esses parâmetros são uma medida da mistura de estados de acoplamento intermediário ${ }^{7} \mathrm{~F}_{0}$ componentes do estado ${ }^{7} \mathrm{~F}_{2}$ e ${ }^{7} \mathrm{~F}_{4}$. Como pode ser observado, os maiores valores de $\mathrm{R}_{02}$ e de $\mathrm{R}_{04}$ foram obtidos para o marcador, evidenciando a maior intensidade da transição ${ }^{5} \mathrm{D}_{0} \rightarrow{ }^{7} \mathrm{~F}_{0}$, resultante da mistura dos $\mathrm{J}$ 's, e demonstrando que nesse caso o operador de posto 4 também contribui na mistura dos J's.

Na FIG. 5.22 apresenta-se a micrografia do sistema $\mathrm{Hb}$ AS-marcador e podemos observar as hemácias nos MEVS A e B e as partículas do marcador com o tampão. 


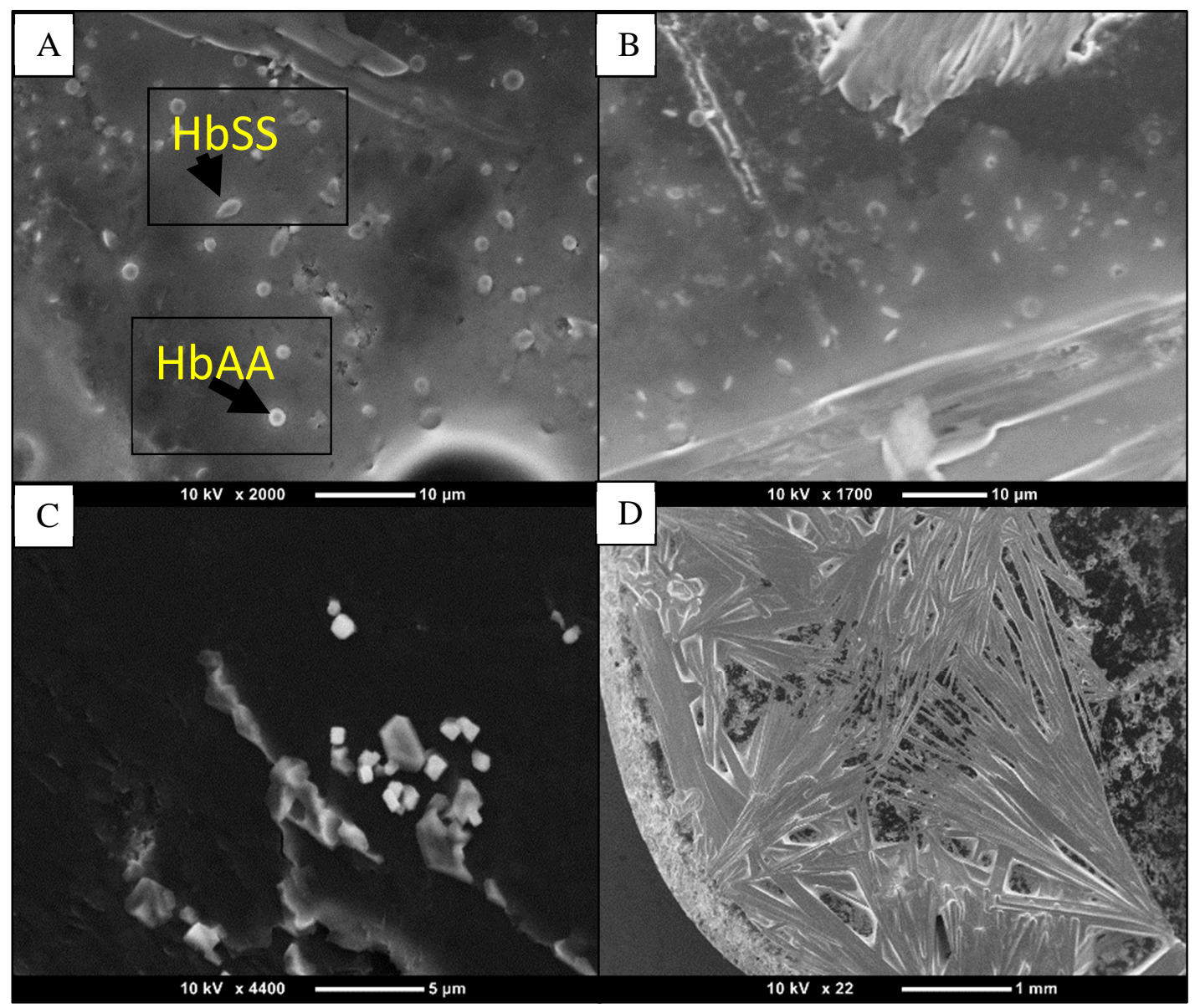

FIGURA 5.22. Microscopia Eletrônica de Varredura. A: hemácias do padrão Hb AS na solução tampão; B: hemácias do padrão Hb AS na solução tampão em um campo maior mostrando além das hemácias o tampão e as partículas do marcador; C: o marcador e D: o tampão fosfato.

A Fig 5.23 mostra o marcador $\left[\mathrm{Eu}(\mathrm{TTA})_{3}(4-\mathrm{picNO})_{2}\right]$ atuando no exame do tipo point of care desenvolvido neste trabalho e como mostrado na Fig 5.23 a hemoglobina SS é mais marcada do que as demais. 

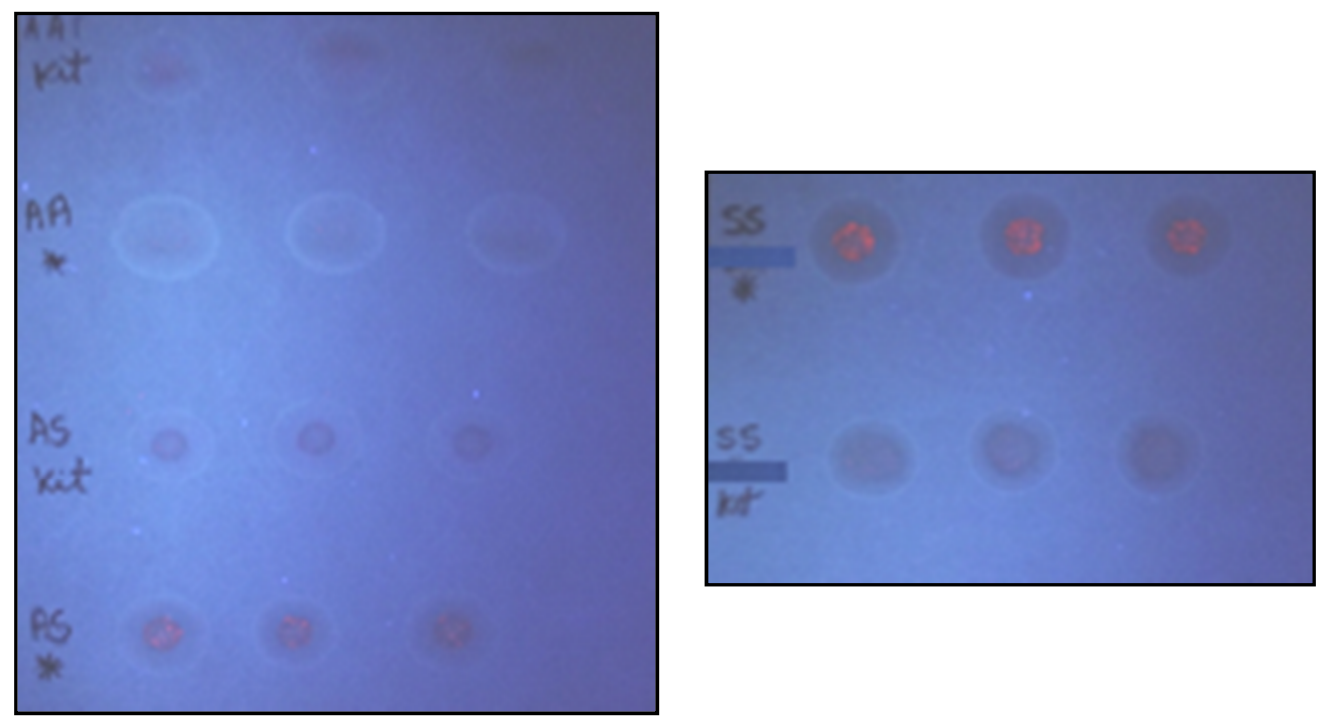

FIGURA 5.23. Exemplo da utilização do marcador no exame tipo point of care.

As cores na região do espectro visível podem ser reproduzidas pela combinação de três componentes monocromáticos. A Comissão Internacional de l'Eclairage (CIE) tem adotado um colorímetro padrão que representa os atributos de cor através de um diagrama tridimensional. Os vetores cartesianos deste diagrama tridimensional são derivados dos estímulos espectrais $x(\lambda), y(\lambda)$ e $z(\lambda)$ (FIG. 5.24) gerados no olho humano devido à incidência de luz. A curva $y(\lambda)$, por exemplo, corresponde à resposta fotônica da cor verde do olho e também compreende toda a região do visível, esta curva é normalizada em um pico em $550 \mathrm{~nm}^{[44,45]}$. 


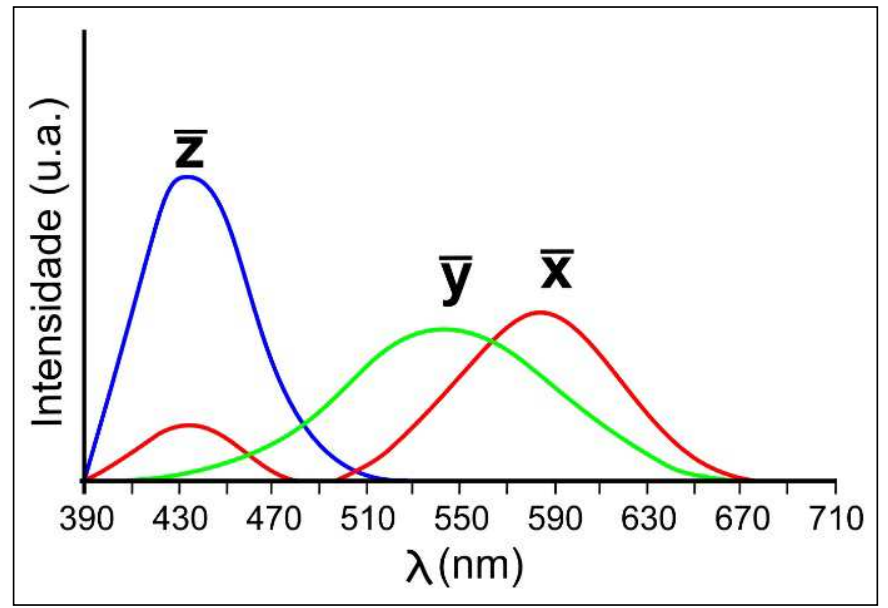

FIGURA 5.24. Curvas das cores padrões CIE para $x(\lambda), y(\lambda)$ e $z(\lambda)$.

As coordenadas $\mathrm{x}, \mathrm{y}$, e $\mathrm{z}$ de cores CIE são definidas pelas seguintes relações:

$$
x=\frac{X}{X+Y+Z} \quad y=\frac{Y}{X+Y+Z} \quad z=\frac{Z}{X+Y+Z}
$$

Onde $\mathrm{X}, \mathrm{Y}$ e Z são calculados pela seguinte integração sob a curva de toda a região do espectro visível:

$$
X=\int d \lambda \phi(\lambda) \bar{x}(\lambda) \quad Y=\int d \lambda \phi(\lambda) \bar{y}(\lambda) \quad Z=\int d \lambda \phi(\lambda) \bar{z}(\lambda)
$$

Onde $\phi(\lambda)$ neste trabalho corresponde à curva de emissão eletroluminescente.

Geralmente, identificam-se apenas os valores de x e y, já que z pode ser determinado a partir de x e y. Em outras palavras, o mapa de cor pode ser expresso como uma projeção bidimensional em um plano $x y$. Este plano é definido como o diagrama de cromaticidade padrão CIE (FIG 5.25). Todas as cores do espectro visível podem ser representadas neste diagrama através da determinação dos valores de x e y.

A FIG 5.25 apresenta o diagrama de cromaticidade CIE ilustrando as coordenadas das cores emitidas pelo marcador e pelos sistemas marcador- Hemoglobina 
(298K). A) diagrama e B) gráfico mostrando a posição XY. Estes dados foram obtidos a partir dos espectros de emissão.

Estes sistemas apresentam alta intensidade de emissão vermelha e verde e possibilitam sua percepção a olho nu (FIG.5.25). Já na TAB. 5.2 têm-se as coordenadas de cromaticidade para marcador e para os sistemas com o marcador- Hemoglobina (298K). Pode-se afirmar que, embora se visualize a cor vermelha na emissão destes materiais elas não são puras, pois se apresentam fora dos vértices do diagrama.
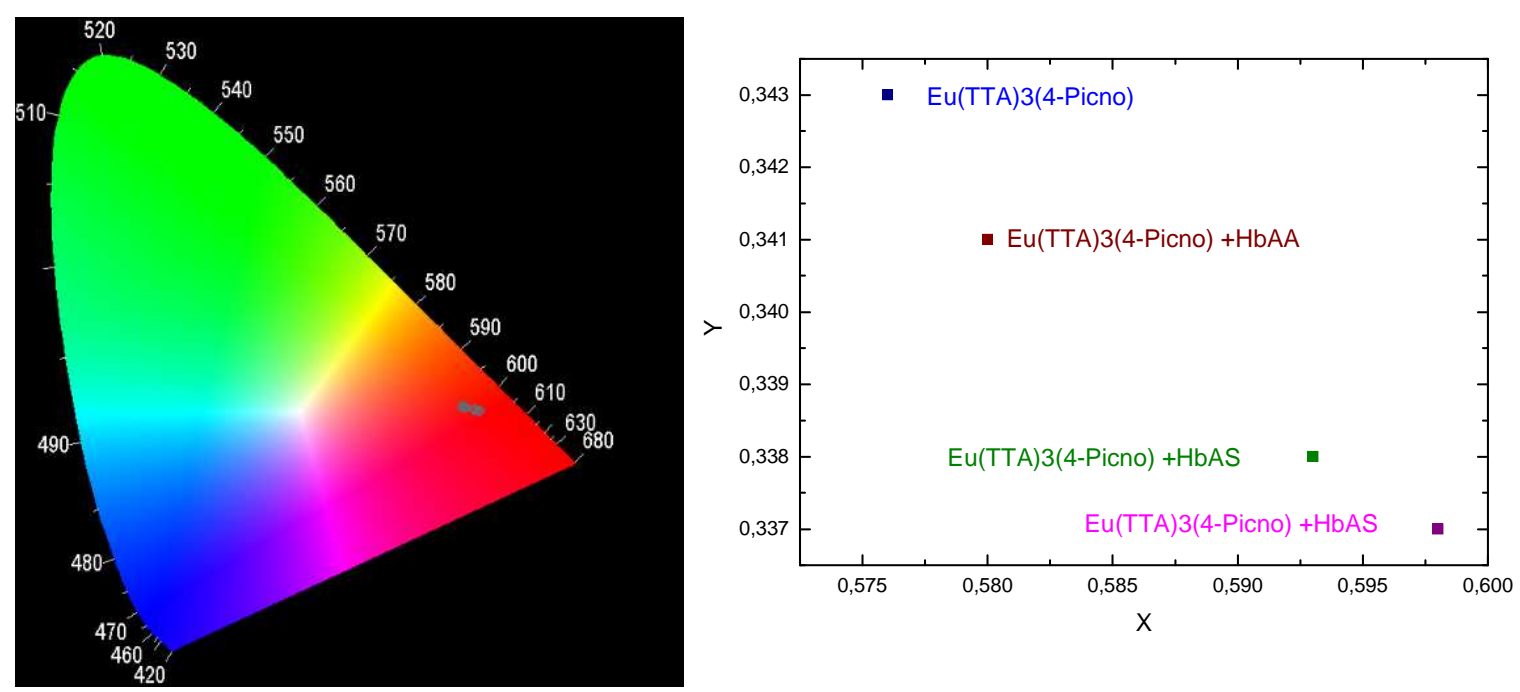

FIGURA 5.25. Diagramas de cromaticidade CIE ilustrando as coordenadas das cores emitidas pelo marcador e pelos sistemas marcador- Hemoglobina $(298 \mathrm{~K})^{[44]}$.

TABELA 5.2. Valores aproximados das coordenadas de cores dos materiais funcionalizados.

\begin{tabular}{lcc}
\hline \multicolumn{1}{c}{ Sistemas } & $\mathbf{x}$ & $\mathbf{y}$ \\
\hline$\left[\mathrm{Eu}(\mathrm{TTA})_{3}(4-\mathrm{picNO})_{2}\right]$ sol & 0,576 & 0,343 \\
{$\left[\mathrm{Eu}(\mathrm{TTA})_{3}(4-\mathrm{icNO})_{2}\right]+\mathrm{HbAA}^{*}$} & 0,598 & 0,337 \\
{$\left[\mathrm{Eu}(\mathrm{TTA})_{3}(4-\mathrm{picNO})_{2}\right] \mathrm{HbAS}^{*}$} & 0,580 & 0,341 \\
{$\left[\mathrm{Eu}(\mathrm{TTA})_{3}(4-\mathrm{icNO})_{2}\right]+\mathrm{HbSS}^{*}$} & 0,593 & 0,338 \\
\hline
\end{tabular}




\subsection{Diferenciação das amostragens biológicas por espectroscopia Raman e espectroscopia de infravermelho por transformada de Fourier (FTIR)}

Neste trabalho foi agregado a espectroscopia IR e Raman para detecção e quantificação dos aminoácidos, ácido glutâmico e valina puros (padrões).

Com base nos resultados desses padrões foram realizadas medidas espectroscópicas de sangue diluído com tampão fosfato concentrado juntamente com os detergentes (saponina ou detergente comercial) e o hidrossulfito de sódio para quantificação indireta da anemia falciforme por meio da diferenciação dos aminoácidos citados e das soluções tanto do kit comercial quanto do kit desenvolvido.

A seguir na figura 5.26 tem-se um resumo das possíveis vibrações de algumas unidades moleculares que formam os aminoácidos de interesse:

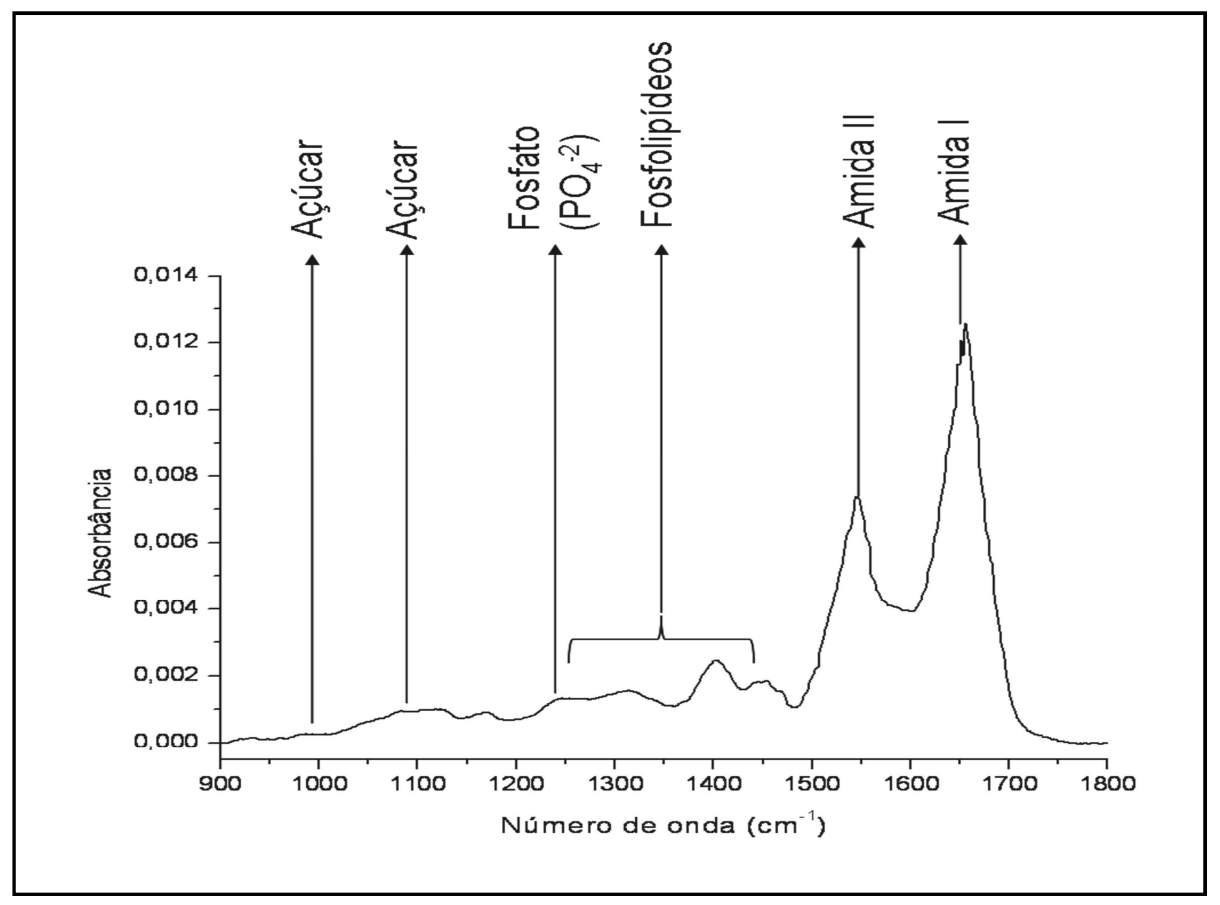

FIGURA 5.26. Espectro teórico das características vibracionais gerais dos aminoácidos. 
Os aminoácidos são moléculas que contêm simultaneamente grupos funcionais amina e ácido carboxílico. Em soluções aquosas de pH neutro, os aminoácidos podem existir em duas formas. Uma pequena fração encontra-se numa forma eletricamente neutra, ou seja, com o grupo amina desprotonado $\left(-\mathrm{NH}_{2}\right)$ e o grupo carboxilo protonado $(-\mathrm{COOH})$. A maioria está, no entanto, numa forma ionizada, em que o grupo amina se encontra protonado $\left(-\mathrm{NH}^{3+}\right)$ e o ácido carboxílico desprotonado a carboxilato (-COO-), denominando-se esta forma de híbrida (zwitteriónica).

Os aminoácidos podem ligar-se entre si com uma ligação amida, que em bioquímica é especificamente designada, neste caso, de ligação peptídica. A ligação ocorre entre o átomo de carbono do grupo carboxilato e o nitrogênio do grupo amina. Neste processo, é libertada uma molécula de água, sendo a ligação final entre o carbono de um grupo carbonilo e o nitrogênio de uma amina secundária. Como consequência, uma cadeia peptídica, ou seja, formada por diversos aminoácidos ligados desta forma, terá um grupo amina numa extremidade (denominada $\mathrm{N}$-terminal) e um grupo carboxilato na extremidade oposta (denominada C-terminal).

\subsubsection{Modos vibracionais L-Valina}

Os modos vibracionais da L-Valina, como observado na figura 5.27, tal como previsto por teoria de grupos pertence a uma estrutura com grupo pontual $\mathrm{C}_{2}$, e espera-se que os modos das duas representações irredutíveis do grupo $\mathrm{C}_{2}$ sejam ativas tanto no infravermelho quanto no Raman. 


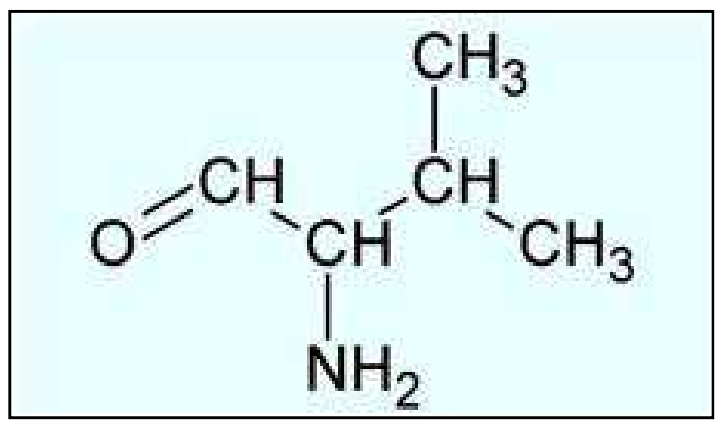

FIGURA 5.27. Estrutura L-valina. Ácido 2-aminovalérico ou Ácido 2-amino-3-metilbutanóico $\left(\mathrm{C}_{5} \mathrm{H}_{11} \mathrm{O}_{2} \mathrm{~N}\right)$ - (Butantã).

Através dos resultados observa-se na figura 5.28, que as bandas entre 3224 e $3402 \mathrm{~cm}^{-1}$ representam a deformação axial de $\mathrm{OH}$ associada a pontes de hidrogênio. As absorções na faixa de 2931 a $2854 \mathrm{~cm}^{-1}$ estão associadas à deformação axial de $\mathrm{C}-\mathrm{H}$ alifático e a banda em $2360 \mathrm{~cm}^{-1}$ é característica do gás $\mathrm{CO}_{2}$. O número de onda de 1735 $\mathrm{cm}^{-1}$ é representado pela deformação axial de grupos ésteres alifático, tal como, $\mathrm{C}=\mathrm{O}$ e $\mathrm{C}$ O. A absorção em $1647 \mathrm{~cm}^{-1}$ refere-se à deformação axial de intensidade fraca da ligação insaturada de grupos etilenos $\mathrm{C}=\mathrm{C}$. A banda de absorção em $1465 \mathrm{~cm}^{-1}$ destaca a deformação angular dos grupos $\mathrm{C}-\mathrm{H}$ e $\mathrm{CH}_{2}$. Duas absorções de extrema importância são as que ocorrem em $1245 \mathrm{~cm}^{-1}$ e entre 723 e $817 \mathrm{~cm}^{-1}$, pois representam a deformação axial de grupos fosfatos alifáticos $\mathrm{P}=\mathrm{O}, \mathrm{P}-\mathrm{O}$ e $\mathrm{P}-\mathrm{O}-\mathrm{C}$, respectivamente; característicos de fosfolipídeos. As bandas em $1064 \mathrm{~cm}^{-1}$ e $1020 \mathrm{~cm}^{-1}$, representam respectivamente, a deformação axial de $\mathrm{C}-\mathrm{O}-\mathrm{C}$ e a deformação axial de amina primária $\mathrm{C}-\mathrm{N}^{[46]}$.

Algumas vezes, absorções que ocorrem no NIR são capazes de caracterizar e identificar compostos, como no caso da caracterização de aminas primárias, secundárias e terciárias. Contudo, uma atribuição precisa de bandas na região do NIR é difícil devido ao fato de que uma simples banda pode ser atribuída a uma combinação de sobretons e bandas de combinação, todas severamente sobrepostas ${ }^{[47,48]}$.

Para isso, começa-se discutindo a origem da banda observada em aproximadamente $523 \mathrm{~cm}^{-1}$. É interessante destacar que na verdade este pico é um dupleto e representa modos associados a vibração do tipo rocking do $\mathrm{CO}_{2}, \mathrm{r}\left(\mathrm{CO}_{2}\right)$. Uma banda 
observada em $261 \mathrm{~cm}^{-1}$ foi atribuída como uma vibração do tipo deformação da estrutura $\mathrm{NCC}, \delta(\mathrm{NCC})$.

Pode-se também atribuir bandas observadas neste estudo na L-Valina nas frequências de 254 e $264 \mathrm{~cm}^{-1}$; nota-se que estas são bandas de muito baixa intensidade, e observa-se a existência de quatro picos em 250; 300; 768 e $793 \mathrm{~cm}^{-1}$. Uma destas bandas pode ser associada a uma vibração do tipo deformação do $\mathrm{CO}_{2}, \delta\left(\mathrm{CO}_{2}\right)$. Os picos em 1413 , 1438 e $1470 \mathrm{~cm}^{-1}$ podem ser associados a deformação do $\mathrm{CH}_{3}$.

A banda larga que aparece centrada em aproximadamente $2950 \mathrm{~cm}^{-1}$ é atribuída às vibrações do estiramento do grupo $\mathrm{CH}$.

$\mathrm{Na}$ espectroscopia Raman por Transformada de Fourier na região entre aproximadamente 1750 e $2500 \mathrm{~cm}^{-1}$ não aparece nenhuma banda Raman como acontece com outros cristais de aminoácidos. Assim, o espectro está separado em duas regiões distintas, uma com bandas em $1750 \mathrm{~cm}^{-1}$ e outra com picos entre 2550 e $3100 \mathrm{~cm}^{-1}$.

Observa-se que na região em torno de $3000 \mathrm{~cm}^{-1}$ as bandas são bem mais intensas do que nas demais regiões; devido a pequenas variações de particulados na solução. 


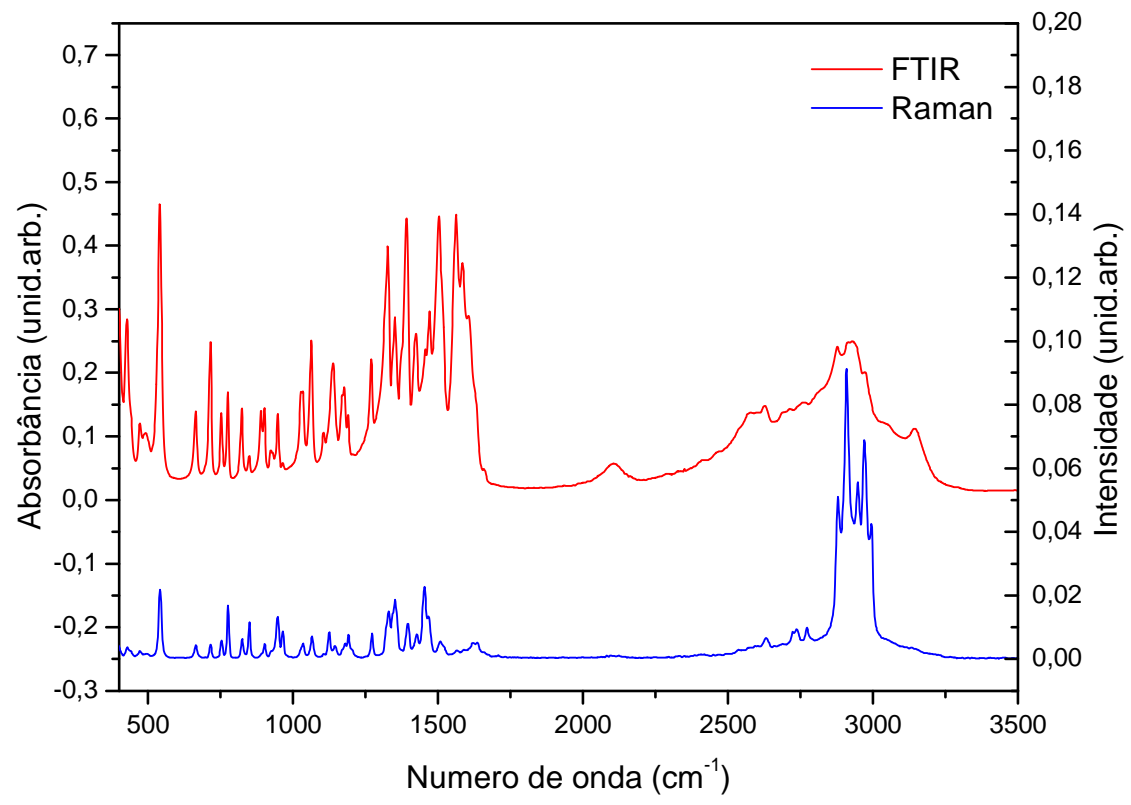

FIGURA 5.28. Espectro de infravermelho e Raman da valina evidenciando as bandas de amida I e II entre aproximadamente 1500 e $1700 \mathrm{~cm}^{-1}$.

\subsubsection{Modos vibracionais do L-ácido glutâmico}

Os resultados do infravermelho mostraram que a interação do L-ácido glutâmico, estrutura observada na figura 5.29, acontece pelo grupo $\mathrm{NH}_{2}$, entretanto outros grupos como $\mathrm{COO}^{-}$e $\mathrm{CH}_{3}$ também podem estar envolvidos.

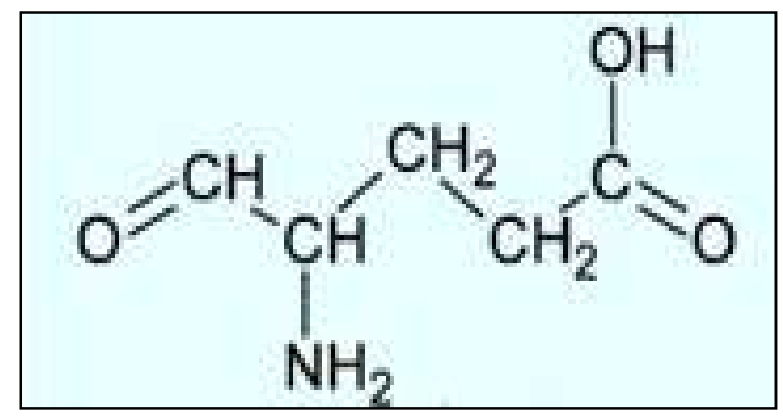

FIGURA 5.29. Estrutura L-ácido glutâmico $\left(\mathrm{C}_{5} \mathrm{H}_{9} \mathrm{NO}_{4}\right)$ - (Ajinomoto/Butantã). 
Na figura 5.30, com base na estrutura do aminoácido em estudo, encontrou-se uma banda que corresponde ao modo de estiramento $\mathrm{OH}$, quatro bandas correspondentes aos estiramentos $\mathrm{NH}$, duas bandas correspondentes aos estiramentos $\mathrm{CH}$, a vibração do grupo $\mathrm{C}=\mathrm{O}$, e uma banda correspondente à ligação $\mathrm{C}=\mathrm{N}$, todas elas na região de maior energia.

Com relação aos modos de estiramento $(\mathrm{CH})$, por meio da segunda derivada do espectro no infravermelho foi possível atribuir as bandas de absorção em: 3176, 2971, 2921 e $2854 \mathrm{~cm}^{-1}$, próximas aos valores experimentais das bandas atribuídas aos modos vibracionais vas $(\mathrm{CH}), \operatorname{vas}(\mathrm{CH}), \operatorname{vs}(\mathrm{CH})$ e $v s(\mathrm{CH})$, respectivamente.

Como se sabe, as carboxilas absorvem na região espectral entre aproximadamente 1700 e $1500 \mathrm{~cm}^{-1}$ encontradas experimentalmente em $1656 \mathrm{~cm}^{-1}$ (IR) e em, 1638 (Raman) e $1643 \mathrm{~cm}^{-1}$ para os modos C=O. A seguir far-se-á breve análise espectral de IR e Raman dos padrões de sangue total.

A quantidade de aminoácidos adsorvidos foi medida e a interação entre aminoácidos e sangue foi estudada usando espectroscopia Raman e infravermelho.

Os espectros da $\mathrm{Hb} \mathrm{AA}$ e $\mathrm{Hb}$ AS apresentaram-se muito similares, com exceção de algumas bandas em 1450, 1480 e $1750 \mathrm{~cm}^{-1}$ ausentes no Raman. Para todas as amostras $\mathrm{Hb}$ AA novas bandas e aumento da intensidade foram observadas.

Pode-se observar a banda dos modos vibracionais, centrada em $1636 \mathrm{~cm}^{-1}$, que é atribuída à presença de amida I. 


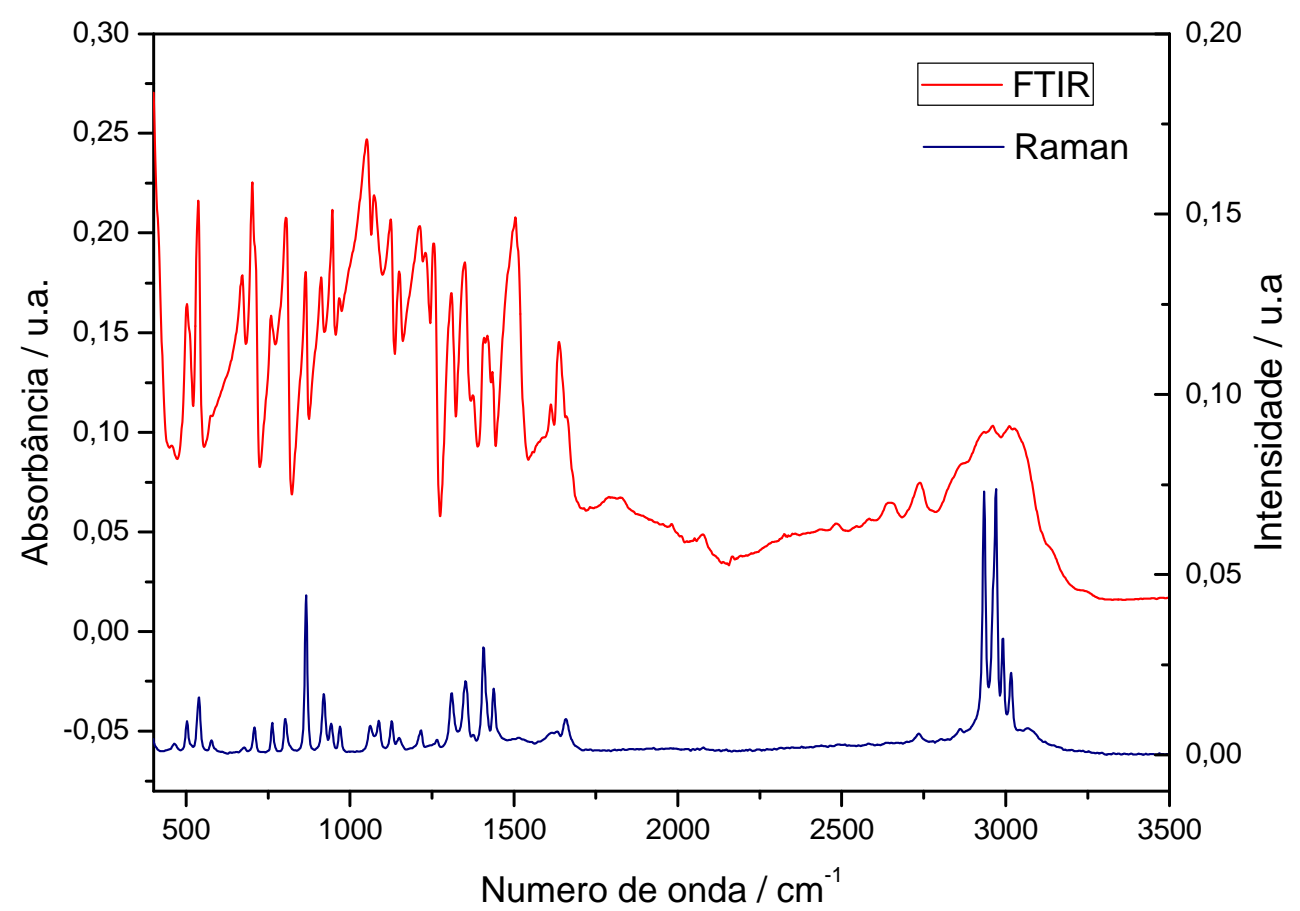

FIGURA 5.30. Espectro de infravermelho e Raman do ácido glutâmico evidenciando as bandas de amida I e II entre aproximadamente 1500 e $1700 \mathrm{~cm}^{-1}$.

Pode-se notar, no espectro de infravermelho da figura 5.31, a preservação das bandas de amida I e II nas amostras Hb AA por IR evidenciando a presença do ácido glutâmico.

Verificou-se que as soluções são qualitativamente idênticas em termos de intensidade espectral.

Com base nos resultados de IR observamos que a metodologia para Raman pode ser melhorada a fim de facilitar a visualização das bandas espectrais de maior interesse e atenuar a relação sinal-ruído das amostras de sangue diluídas.

Amidas secundárias, que estão presentes, bem como todas as amidas, mostram uma banda de estiramento $\mathrm{C}=\mathrm{O}$, que é denominada amida I entre $1680 \mathrm{e} 1630 \mathrm{~cm}^{-1}$. Nesse composto, a mesma é atribuída na próxima a $1642 \mathrm{~cm}^{-1}$ (IV) e $1655 \mathrm{~cm}^{-1}$ (R). Entretanto, a 
banda correspondente à amida II, causada primariamente por deformações $\mathrm{NH}$, são atribuídas sem nenhuma coincidência com outras bandas, aparecendo em $1534 \mathrm{~cm}^{-1}$ (IV).

Como bandas de estiramento $\mathrm{OH}$ de moléculas de água ocorrem próximas àquelas do grupo carboxila, é possível dizer que as bandas mostradas nos espectros experimentais observadas nessa região poderiam também estar associadas às da molécula de água.

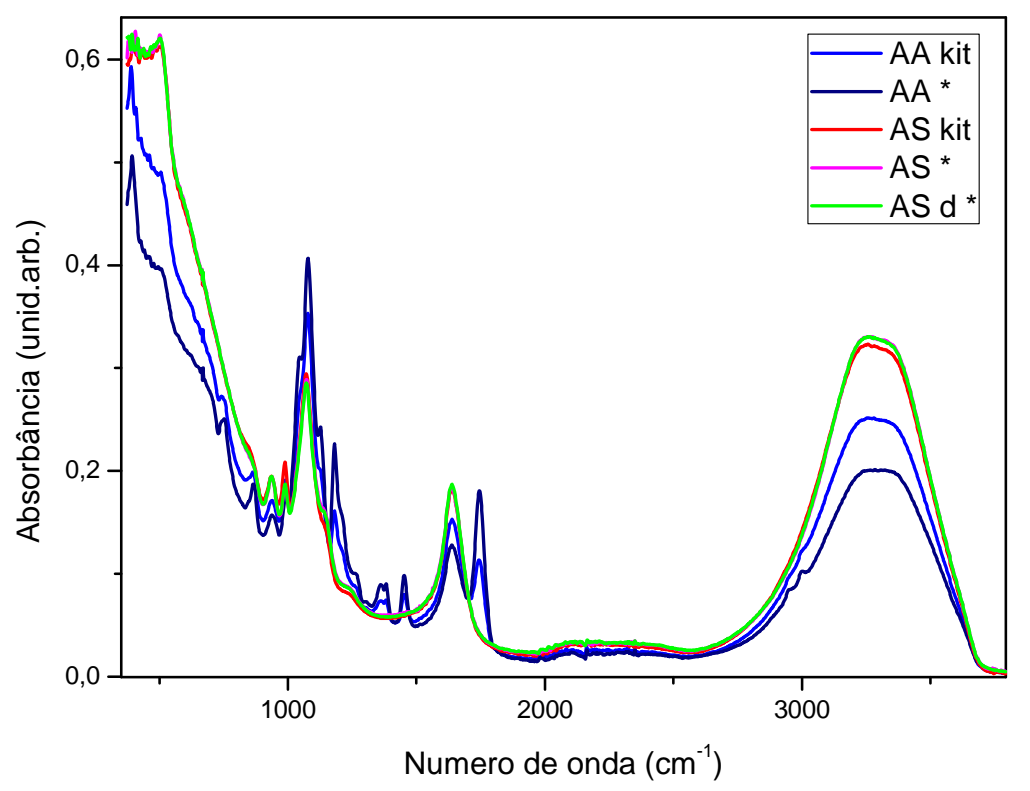

FIGURA 5.31. Espectro de infravermelho dos padrões de sangue total evidenciando as bandas de amida I e II entre aproximadamente 1500 e $1700 \mathrm{~cm}^{-1}$. Legenda: Hb AA kit e $\mathrm{Hb}$ AS kit - ensaios biológicos com a solução do kit comercial. Hb AA*, $\mathrm{Hb}^{\mathrm{AS}} \mathrm{A}^{*}$ e $\mathrm{Hb} \mathrm{AS}$ d* - ensaios biológicos com as soluções desenvolvidas no laboratório e $\mathrm{d}^{*}$ - solução desenvolvida com detergente comercial. $\mathrm{Hb}$ AA (sangue sem falciforme) e $\mathrm{Hb}$ AS (sangue com traço falciforme).

No presente trabalho, os principais aminoácidos também foram analisados separadamente por espectroscopia Raman, como observado na figura 5.32. Foi feita uma tentativa de correlacioná-los com os espectros de sangue diluídos, porém os resultados não foram satisfatórios, pois os espectros vibracionais medidos na fase líquida sofreram 
interferências do efeito do tampão fosfato e a sensibilidade do equipamento não atendeu às expectativas.

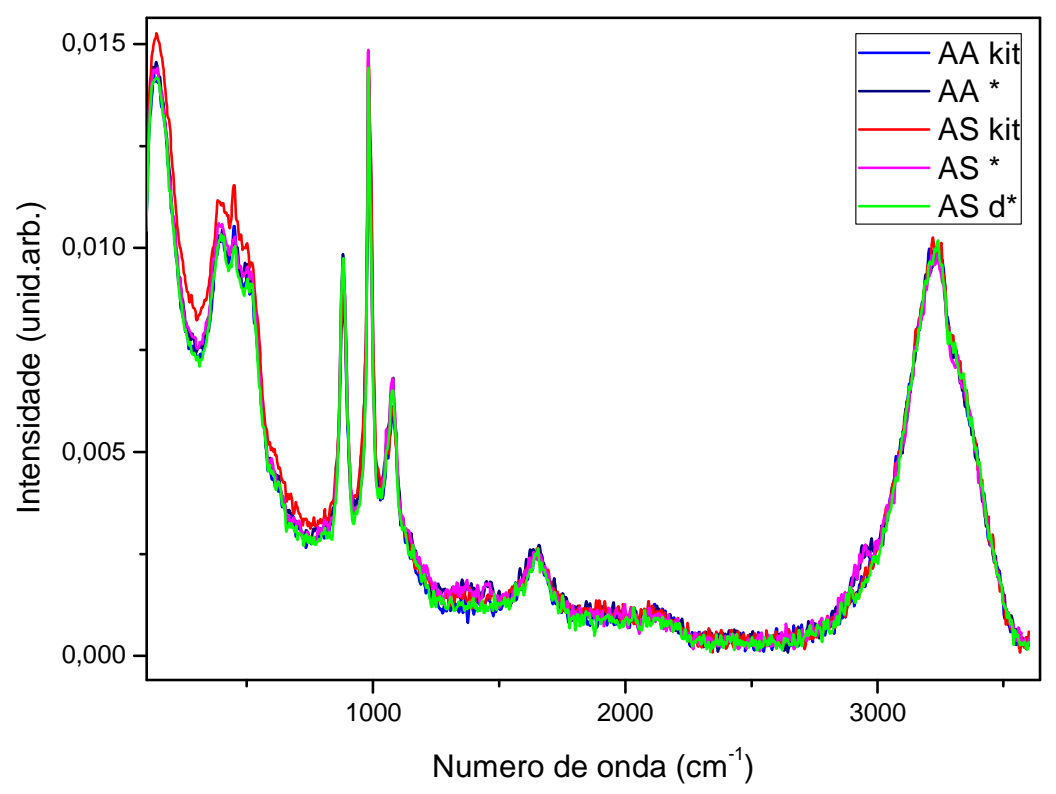

FIGURA 5.32. Espectro Raman dos padrões de sangue total. Legenda: Hb AA kit e Hb AS kit - ensaios biológicos com a solução do kit comercial. $\mathrm{Hb}^{\mathrm{A}} \mathrm{A}^{*}, \mathrm{Hb} \mathrm{AS} * \mathrm{e} \mathrm{Hb} \mathrm{AS}$ d *- ensaios biológicos com as soluções desenvolvidas no laboratório e d* - solução desenvolvida com detergente comercial. Hb AA (sangue sem falciforme) e $\mathrm{Hb}$ AS (sangue com traço falciforme).

\subsection{Análise multivariada por espectroscopia Raman e espectroscopia de infravermelho (FTIR)}

Esta parte do estudo foi realizada em parceria com o departamento de Nanociências e Materiais Avançados da Universidade Federal do ABC/UFABC.

Dentre os métodos estatísticos convencionais, a Análise de Componentes Principais (PCA) tem sido de grande aplicação em diversas áreas, como a Física, a Matemática e a Geografia. 
A análise de componentes principais consiste essencialmente em reescrever as coordenadas das amostras em outro sistema de eixo mais conveniente para a análise dos dados.

Em outras palavras, as n-variáveis originais, geram através de suas combinações lineares, n-componentes principais, cuja principal característica, além da ortogonalidade, é que são obtidos em ordem decrescente de máxima variância, ou seja, a componente principal 1 detém mais informação estatística que a componente principal 2 , que por sua vez tem mais informação estatística que a componente principal 3 e assim por diante.

Este método permite a redução da dimensionalidade dos pontos representativos das amostras, pois embora a informação estatística presente nas n-variáveis originais seja a mesma dos n-componentes principais, é comum obter em apenas 2 ou 3 dos primeiros componentes principais mais que $90 \%$ desta informação.

Portanto, os espectros das amostras biológicas, nas figuras 5.33 e 5.34, foram corrigidos com linha de base e normalizados através da área das bandas do fosfato e das amidas. Depois disto, cada espectro foi convertido em segunda derivada utilizando-se o algoritmo de Savitzky/Golay com 9 pontos na janela.

Estatisticamente, a análise foi efetuada usando o Método de Ward, que utiliza uma análise de variância mínima (ou mais conhecida como análise das distâncias).

A análise estatística bivariante também foi realizada, baseando-se em duas faixas distintas de cada espectro: a primeira baseada no pico das amidas para o infravermelho e o pico do fosfato para o Raman.

Foram utilizados os dados da matriz com números de onda versus amostras e este resultado foi inserido numa matriz transposta para proceder com o PCA. O PCA foi feito de PC1 até PC3, pois representa mais de 90\% da população significante. Os gráficos foram plotados em PC1xPC2. 
O gráfico da componente principal 1 versus a componente principal 2 forneceu uma janela privilegiada (estatisticamente) para observação dos pontos no espaço ndimensional e assim sucessivamente com fator 2 e 4, 5 e 6 e outras combinações.

A análise de componentes principais também pode ser usada para julgar a importância das próprias variáveis originais escolhidas, ou seja, as variáveis originais com maior peso (loadings) na combinação linear dos primeiros componentes principais são as mais importantes do ponto de vista estatístico ${ }^{[31,32]}$.

Foi feita uma tentativa de correlacionar os resultados com os espectros de sangue diluídos, porém os resultados não foram satisfatórios, pois os espectros vibracionais medidos na fase líquida sofreram interferências do efeito do tampão fosfato e a sensibilidade do equipamento não atendeu às expectativas, além da baixa quantidade de amostras para realização de um método estatístico, como demonstrado nas figuras 5.33 e 5.34 .

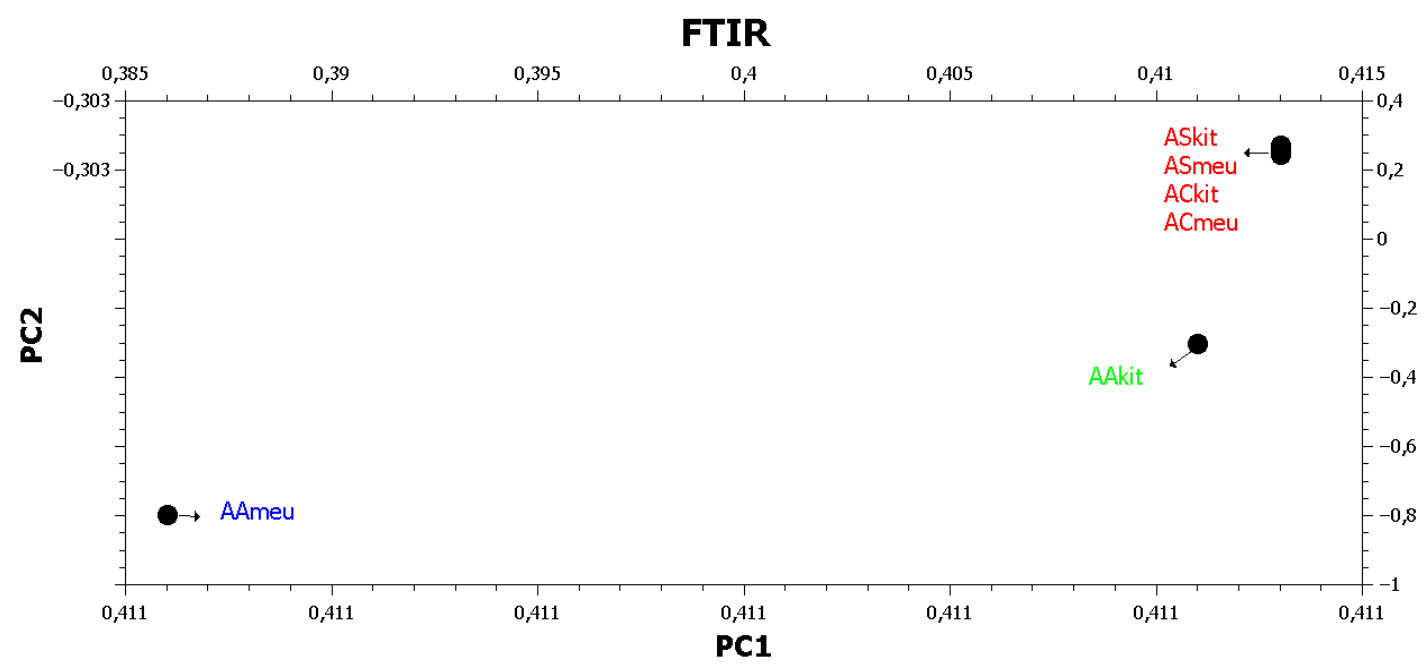

FIGURA 5.33. Análise multivariada por espectroscopia de infravermelho (FTIR). Legenda: Hb AA kit e Hb AS kit - ensaios biológicos com a solução do kit comercial. Hb AA (meu), Hb AS (meu) - ensaios biológicos com as soluções desenvolvidas no laboratório. $\mathrm{Hb} \mathrm{AA}$ (sangue sem falciforme) e $\mathrm{Hb}$ AS (sangue com traço falciforme). Desconsiderar ACkit e ACmeu, pois foram testes fora do conteúdo deste trabalho. 


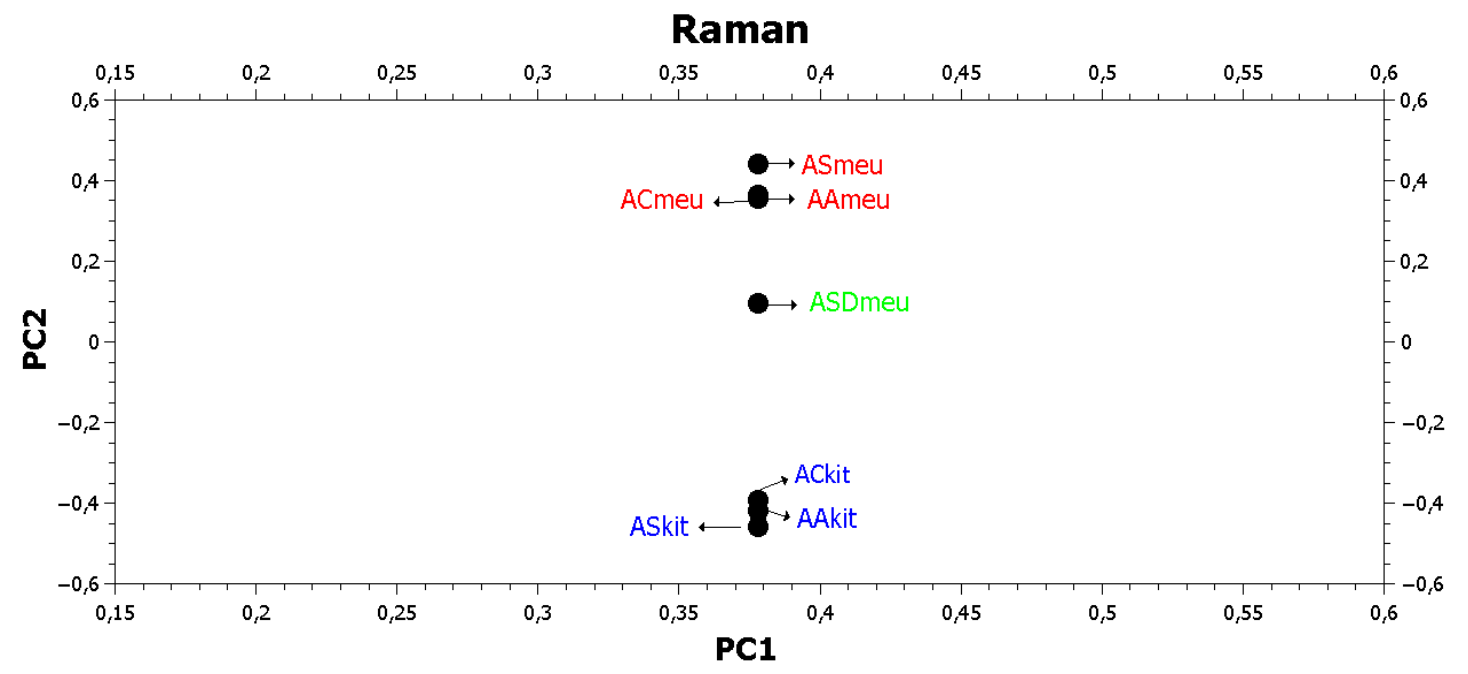

FIGURA 5.34. Análise multivariada por espectroscopia Raman. Legenda: Hb AA kit e Hb AS kit - ensaios biológicos com a solução do kit comercial. Hb AA (meu), Hb AS (meu) e $\mathrm{Hb}$ ASD (meu) - ensaios biológicos com as soluções desenvolvidas no laboratório. Hb AA (sangue sem falciforme) e $\mathrm{Hb}$ AS (sangue com traço falciforme). Desconsiderar ACkit e ACmeu, pois foram testes fora do conteúdo deste trabalho. 


\section{REFERÊNCIAS BIBLIOGRÁFICAS}

[1] PASCAL, J.-L.; FAVIER, F.; Inorganic perchlorato complexes. Coord. Chem. Rev.; v. 180, p. 865-902, 1998.

[2] NAKAMOTO, K. Infrared and Raman Spectra of Inorganic and Coordination Compounds. New York: John Wiley \& Sons, 1978.

[3] MEHROTRA, R.C.; BOHRA, R.; GAUR, D.P.; Metal $\beta$-diketonates and Allied Derivatives. London: Academic Press, 1978.

[4] HOLTZCLAW Jr., H.F.; COLLMAN, J.P. Infrared absorption of metal chelate compounds of 1,3-Diketones. J. Am. Chem. Soc., v. 79, p. 3318-3322, 1957.

[5] NAKAMOTO, K.; MORIMOTO, Y.; MARTELL, A.E. Infrared spectra of metal chelate compounds. v. effect of substituents on the infrared spectra of metal acetylacetonates. J. Phys. Chem., v. 66, p. 346-348, 1962.

[6] SHIGA, H.; Pharm. Bull., v. 4, p. 460-469, 1956.

[7] KIDA, S.; QUAGLliANO, J.V.; WALMSLFY, J.A.; TYRRE, S.Y. Infra-red studies of pyridine $\mathrm{N}$-oxide and its $\mathrm{Co}(\mathrm{II}), \mathrm{Ni}(\mathrm{II}), \mathrm{Cu}(\mathrm{II}), \mathrm{Zn}(\mathrm{II}), \mathrm{Al}(\mathrm{III}), \mathrm{Cr}(\mathrm{III}), \mathrm{Fe}(\mathrm{II})$, $\mathrm{Fe}(\mathrm{III})$ and $\mathrm{Sn}(\mathrm{IV})$ complexes in the 3-15 $\mu$ region. Spectrochim. Acta, v. 19, p. 189-199, 1963.

[8] KAKIUTI, Y.; KIDA, S. QUAGLIANO, J.V. Metal-ligand stretching, N-O stretching and $\mathrm{C}-\mathrm{H}$ out-of-plane bending vibrations of pyridine $\mathrm{N}$-oxide and hexakis (pyridine N-oxide) metal perchlorates. Spectrochin. Acta, v. 19, p. 201-211, 1963.

[9] DE OLIVEIRA, W. Compostos de adição entre nitratos, cloretos e perclorados de itrio e alguns lantanídeos (III) e a lutidina -N-oxido. 1975. Tese (doutorado) - Instituto de Química, Universidade de São Paulo, São Paulo.

[10] MATOS, J.R. Estudo comparativo dos compostos de adição entre metanosulfonatos de lantanídeos (III) e aminoácidos aromáticos como ligantes. 1989. Tese (doutorado) - Instituto de Química, Universidade de São Paulo, São Paulo.

[11] PECHARSKY, V.K.; ZAVALIK, P.Y. Fundamentals of powder diffraction and structural characterization of materials. 1 ed. New York: Springer Science+Business Media, 2005. 
[12] MALTA, O.L.; BRITO, H.F.; MENEZES, J.F.S.; GONÇALVES E SILVA, F.R.; ALVES Jr, S.; FARIAS Jr, F.S.; ANDRADE, A.V.M. Spectroscopic properties of a new light-converting device Eu(thenoyltrifluoroacetonate)3 2(dibenzyl sulfoxide). A theoretical analysis based on structural data obtained from a sparkle model. J. Lumin., v. 75, p. 255 268, 1997.

[13] COTTON, F.A Chemical Application of Group Theory. New York: WileyIntercience, 1971.

[14] BÜNZLI, J.-C.G.; CHOPPIN, G.R. Lanthanide Probes in Life, Chemical and Earth Sciences - Theory and Practice. Amsterdam: Elsevier, 1989.

[15] RICHARDSON, F.S. Terbium(III) and europium(III) ions as luminescent probes and stains for biomolecular systems. Chem.Rev., v. 82, p. 541-552, 1982.

[16] TEOTONIO, E.E.S. Síntese e investigação das propriedades fotoluminescentes de dispositivos moleculares conversores de luz (DMCL) de complexos dicetonatos de terras raras com ligantes amidas. 2004. Tese (doutorado). Instituto de Química, Universidade de São Paulo.

[17] FORSBERG, J. H. Complexes of lanthanide(III) ions with hidrogen donor ligands. Coord. Chem. Rev., v. 10, p. 195-226, 1973.

[18] YANG, X.; KANTER, J.; PIETY, N.Z.; BENTON, M.S.; VIGNES, S.M.; SHEVKOPLYAS, S.S. A simple, rapid, low-cost diagnostic test for sickle cell. Lab. Chip., v. 13, p. 1464-1467, 2013.

[19] BORISOV, S.M.; WOLFBEIS, O.S. Optical Biosensors. Chem. Rev., v.108, p. 423-461, 2008.

[20] MICHALET, X.; PINAUD, F.F.; BENTOLILA, L.A.; TSAY, J.M.; DOOSE, S.; LI, J.J.; SUNDARESAN, G.; WU, A.M.; GAMBHIR, S.S.; WEISS, S. Quantum dots for live cells, in vivo imaging, and diagnostics. Science, v. 307, p. 538-544, 2005.

[21] MRINMOY, D.; PARTHA, S.G.; VINCENT, M.R. Applications of nanoparticles in biology. Adv. Mater., v. 20, p. 4225-4241, 2008.

[22] BRUCHEZ, M.; MORONNE, M.; GIN, P.; WEISS, S.; ALIVISATOS, A.P. Semiconductor nanocrystals as fluorescent biological labels. Science, v. 281, p. 20132016, 1998. 
[23] CHAN, W.C.W.; NIE, S.M. Quantum dot bioconjugates for ultrasensitive nonisotopic detection. Science, v. 281, p. 2016-2018, 1998.

[24] MEDINTZ, I.L.; UYEDA, H.T.; GOLDMAN, E.R.; MATTOUSSI, H. Quantum dot bioconjugates for imaging, labelling and sensing. Nat. Mater., v. 4, p. 435-446, 2005.

[25] CHARBONNIERE, L.J.; HILDEBRANDT, N.; ZIESSEL, R.F.; LOEHMANNSROEBEN, H.G. Lanthanides to quantum dots resonance energy transfer in time-resolved fluoro-immunoassays and luminescence microscopy J. Am. Chem. Soc., v. 128, p. 12800-12809, 2006.

[26] HANAOKA, K.; KIKUCHI, K.; KOBAYASHI, S.; NAGANO, T. Time-resolved long-lived luminescence imaging method employing luminescent lanthanide probes with a new microscopy system. J. Am. Chem. Soc., v. 129, p. 13502-13509, 2007.

[27] LI, M.; SELVIN, P.R. Luminescent polyaminocarboxylate chelates of terbium and europium: the effect of chelate structure. J. Am. Chem. Soc., v. 117, p. 8132-8138, 1995.

[28] NIRMAL, M.; DABBOUSI, B.O.; BAWENDI, M.G.; MACKLIN, J.J.; TRAUTMAN, J.K.; HARRIS, T.D.; BRUS, L.E. Fluorescence intermittency in single cadmium selenide nanocrystals. Nature, v. 383, p. 802-804, 1996.

[29] WANG, L.Y.; YAN, R.X.; HAO, Z.Y.; WANG, L.; ZENG, J.H.; BAO, H.; WANG, X.; PENG, Q.; LI, Y.D. Fluorescence Resonant Energy Transfer Biosensor Based on Upconversion-Luminescent Nanoparticles. Angew. Chem. Int. Ed., v. 44, p. 60546057, 2005.

[30] SALEH, S.M.; ALI, R.; HIRSCH, T.; WOLFBEIS, O.S. Detection of biotin-avidin affinity binding by exploiting a self-referenced system composed of upconverting luminescent nanoparticles and gold nanoparticles. J. Nanopart. Res., v. 13, p. 4603-4611, 2011.

[31] LIU, C.H.; WANG, Z.; WANG, X.K.; LI, Z.P. Surface modification of hydrophobic $\mathrm{NaYF}_{4}: \mathrm{Yb}, \mathrm{Er}$ upconversion nanophosphors and their applications for immunoassay. Sci. China Chem., v. 54, p. 1292-1297, 2011.

[32] SON, A.; DOSEV, D.; NICHKOVA, M.; MA, Z.; KENNEDY, I.M.; SCOW, K.M.; HRISTOVA, K.R. Amperometric biosensor based on coentrapment of enzyme and mediator by gold nanoparticles on indium-tin oxide electrode Anal. Biochem., v. 370, p. 186-194, 2007. 
[33] ZHANG, J.; LI, B.; ZHANG, L.; JIANG, H. An optical sensor for Cu(II) detection with upconverting luminescent nanoparticles as an excitation source. Chem. Commun., v. 48, p. 4860-4862, 2012.

[34] ZHANG, Y.; TANG, Y.R.; LIU, X.; ZHANG, L.C.; LV, Y. A highly sensitive upconverting phosphors-based off-on probe for the detection of glutathione. Sens. Actuators B, v. 185, p. 363-369, 2013.

[35] DENG, R.R.; XIE, X.J.; VENDRELL, M.; CHANG, Y.T.; LIU, X.G. Intracellular glutathione detection using mno2-nanosheet-modified upconversion nanoparticles. $\mathbf{J}$. $\mathbf{A m}$. Chem. Soc., v. 133, p. 20168-20171, 2011.

[36] BUNZLI, J.-C.G. Benefitting from the unique properties of lanthanide ions. Acc. Chem. Res., v. 39, p. 53-61, 2006.

[37] BERTINI, I.; KURSUlA, P.; LUCHINAT, C.; PARIGI, G.; VAHOKOSKI, J.; WILMANNSM, Y.J. Accurate solution structures of proteins from X-ray data and a minimal set of NMR data: calmodulin-peptide complexes as examples. J. Am. Chem. Soc., v. 131, p. 5134-5144, 2009.

[38] BERTINI, I.; LUCHINAT, C.; PARIGI, G.; PIERATTELlI, R. Perspectives in paramagnetic NMR of metalloproteins. Dalton Trans., p. 3782-3790, 2008.

[39] BERTINI, I.; GUPTA, Y.K.; LUCHINAT, C.; PARIGI, G.; PEANA, M.; SGHERI, L.; YUAN, J. Paramagnetism-based NMR restraints provide maximum allowed probabilities for the different conformations of partially independent protein domains. $\boldsymbol{J}$. Am. Chem. Soc., v. 129, p. 12786-12794, 2007.

[40] CARNALL, W.T.; CROSSWITHE, H.; CROSSWITHE, H.M. Energy Level Structure and transition probabilities of the Trivalent Lanthanide in LaF3. Argone National Lab. Argonne Illinos, p. 4493, 1977.

[41] JUDD, B.R. Ionic transitions hypersensitive to environment. J. Chem. Phys., v. 70, n. 11, p. 4830-4833, 1979.

[42] LOURENÇO, A.V.S. Partículas de sílica funcionalizadas contendo complexos de $T_{R^{3+}}$ para aplicação como marcadores em ensaios biológicos. 2010. Tese (doutorado), Universidade de São Paulo, São Paulo.

[43] PAGANINI, P.P. Síntese e caracterização de trocadores iônicos inorgânicos a base de óxidos mistos estanho-titânio para utilização na recuperação de cádmio e níquel 
e estudos fotoluminescentes. 2007. Dissertação (Mestrado), Instituto de Pesquisas Energéticas e Nucleares, IPEN/CNEN-SP, São Paulo.

[44] SANTA-CRUZ, P.A.; TELES, F.S. Spectra Lux Software v.1.0, Ponto Quântico Nanodispositivos / RENAMI, 2003

[45] LATVA, M.; TAKAlO, H.; MUKAllA, V.M.; MATACHESCU, C.; RODRÍGUEZ-UBIS, J.C.; KANAKARE, J. Correlation between the lowest triplet state energy level of the ligand and lanthanide(III) luminescence quantum yield. J. Lumin., v. 75, p. 149-169, 1997.

[46] SILVERSTEIN, R.M.; KIEMLE, D.J.; WEBSTER, F.X. Identificação Espectrométrica de Compostos Orgânicos. 6 ed. Rio de Janeiro: LTC, 2000. p. 60-74.

[47] JEROME, J.; WORKMAN, J.R. Interpretive Spectroscopy for Near-Infrared. Appl. Spectrosc. Rev., v. 31, p. 251-320, 1996.

[48] BUMS, D.A.; CIURCZAK, E.W. Handbook of Near-Infrared Analysis. 2 ed. New York: Marcel Dekker, 2001. 


\section{Conclusões e Perspectivas}




\section{CONCLUSÕES}

Sobre os ensaios biológicos Pode-se concluir que o kit desenvolvido apresentou resultados idênticos ao kit comercial, pois:

- tanto as soluções autoclavadas como as não autoclavadas apresentaram a mesma sensibilidade. Isto significa que a exclusão desta etapa poderá promover a diminuição do valor agregado ao kit bem como eliminar a dificuldade dos laboratórios que possuem poucos recursos;

- verificou-se que não é necessário utilizar o conservante 2-cloroacetamida, pois em 45 dias não houve contaminação das soluções tampão por fungos e bactérias;

- a possibilidade de substituição da saponina por detergente comercial Limpol foi bem sucedida, tornando o custo do kit desenvolvido mais baixo quando comparado ao kit internacional;

- a possibilidade de substituição do hidrossulfito de sódio por tiossulfato de sódio foi também bem sucedida, tornando o custo do kit desenvolvido mais baixo.

Sob quaisquer condições adversas será possível preparar essas soluções tampão e levá-las a campo para execução de um rápido diagnóstico.

Haverá a possibilidade de substituição do agente redutor do kit comercial internacional por outros reagentes e não apenas pelo tiossulfato de sódio.

O halo produzido pelo grupo $\mathrm{Hb}$ AA foi homogêneo e claro; o ponto central da mancha de sangue produzido pelo grupo $\mathrm{Hb}$ AS foi significativamente mais escuro e o centro do halo produzido pelo grupo $\mathrm{Hb}$ SS foi significativamente mais escuro e uniforme em relação à $\mathrm{Hb} \mathrm{AS}$. Estes resultados indicam que a metodologia foi eficiente, corroborando com os resultados do kit internacional. 
Até o presente momento, não foi estimado o custo exato do kit desenvolvido neste trabalho, entretanto, considerando os reagentes substituídos e seus custos pode-se calcular um valor 100 vezes menor quando comparado ao que é cobrado pelo kit comercial. O valor atual para compra varia em torno de $\mathrm{R} \$ 700,00$ o kit com 50 análises, ou seja, é pago aproximadamente R \$ 14,00 por diagnóstico/paciente. É visível a possível redução de gastos com o teste desenvolvido pelo grupo que poderá ser aplicado em qualquer região que necessite da triagem diagnóstica populacional, mas principalmente nas comunidades carentes.

Esta é a primeira implementação mais simples de um teste para diagnóstico da anemia falciforme com visualização em papel utilizando a própria cor das hemoglobinas sem a necessidade de complexos enzimáticos.

Portanto, com base nos resultados obtidos concluiu-se que o teste qualitativo apresentou resultados $100 \%$ satisfatórios podendo ser utilizado em pontos isolados do Brasil e em casos de emergência. Tudo indica que a finalização deste trabalho resultará futuramente em um teste não só qualitativo como também quantitativo.

Os dados de espectroscopia de absorção na região do infravermelho indicaram a coordenação do ligante 4-picNO ao $\mathrm{TR}^{3+}$ através dos átomos de oxigênio, porém são dados não conclusivos.

Os espectros de emissão do complexo de $\mathrm{Eu}^{3+}$ exibiram bandas finas oriundas das transições ${ }^{5} \mathrm{D}_{0} \rightarrow{ }^{7} \mathrm{~F}_{0-4}$, dominados pelas transições hipersensíveis ${ }^{5} \mathrm{D}_{0} \rightarrow{ }^{7} \mathrm{~F}_{2}(\sim 612 \mathrm{~nm})$. Os desdobramentos dessas transições, de um modo geral, estão concordantes com um ambiente químico de baixa simetria ao redor do íon $\mathrm{TR}^{3+}$. O complexo de $\mathrm{Eu}^{3+}$ apresentou comportamento não centrossimétrico caracterizado pela alta intensidade luminescente da transição hipersensível, que é proibida por dipolo elétrico em sistemas com centro de inversão.

Com base no número de componentes de cada uma das transições observadas ${ }^{5} \mathrm{D}_{0} \rightarrow{ }^{7} \mathrm{~F}_{\mathrm{J}}(\mathrm{J}=0,1,2,3$ e 4$)$ nos espectros de emissão e pela presença de um único pico atribuído à transição ${ }^{5} \mathrm{D}_{0} \rightarrow{ }^{7} \mathrm{~F}_{0}$ pode-se sugerir que o complexo de Eu $^{3+}$ está consistente com apenas um sítio de simetria que pode ser $\mathrm{C}_{2 \mathrm{v}}, \mathrm{C}_{2}, \mathrm{C}_{1}$ ou $\mathrm{C}_{\mathrm{s}}$. 
As micrografias mostraram que os aglomerados são de tamanho micrométrico e apresentam forma de hexágonos distorcidos, que corroboram com a geometria de prisma trigonal biencapuzado, mas com certa heterogeneidade de tamanho. Partículas na forma esférica não foram obtidas.

A marcação das hemoglobinas com complexo de terra rara não foi conclusiva e possivelmente a $\mathrm{Hb} \mathrm{SS}$ e $\mathrm{Hb}$ AS foram marcadas enquanto que a $\mathrm{Hb} \mathrm{AA}$ suprimiu a marcação. Os espectros de emissão do conjugado Hb-Marcador, apesar de não conclusivos, indicaram que em solução o complexo tem a simetria modificada pela conjugação da proteína.

Os valores de $\Omega_{2}$ apresentam-se maiores do que os de $\Omega_{4}$, mostrando que as interações de segunda ordem são mais importantes nos sistemas utilizados e refletem as mudanças efetuadas pela presença de hemoglobinas conjugadas com o complexo.

Considerando brevemente sobre a espectroscopia de infravermelho das amostras testadas, foram observadas as bandas de interesse, amida I e amida II, que evidenciaram o objeto de estudo deste trabalho, porém os resultados da espectroscopia Raman não foram satisfatórios.

Apesar de todos os esforços dispendidos para o aperfeiçoamento do kit desenvolvido neste trabalho, infelizmente, por falta de amostras biológicas cedidas pelo hospital Universitário da Universidade de São Paulo o método estatístico não foi conclusivo.

\subsection{PERSPECTIVAS}

Para futuros projetos, abre-se uma gama para diversas áreas de pesquisa e novas metodologias poderão ser desenvolvidas, assim como a exploração de novos campos de estudo dentro da espectroscopia no infravermelho e espectroscopia Raman.

Com a contínua parceria da UFABC e um número maior de amostras biológicas, será possível um estudo mais abrangente da segunda derivada espectral e a 
deconvolução de bandas dos espectros em ambas as técnicas. E a partir desses resultados será possível usar tais ferramentas como modelo comparativo do kit desenvolvido neste trabalho. Assim, de posse dos dados finais, ter-se-à informações de grupos estatísticos que se confrontarão com os dados diagnósticos obtidos até o presente momento.

Será possível comprovar a eficácia dos ensaios com uma amostragem maior de material biológico (sangue total).

Comprovar a eficácia do kit desenvolvido através de ajustes metodológicos para estudo da diferenciação das hemoglobinas com a espectroscopia vibracional, pois essas análises poderão direcionar ideias a respeito do que pode ser feito futuramente com essa linha de pesquisa.

Com estes pequenos ajustes o kit desenvolvido pelo grupo poderá se tornar um kit qualitativo e também quantitativo e ser lançado no mercado possibilitando a utilização pela rede pública de saúde do Brasil.

É necessário fazer pequenas mudanças na metodologia das análises, como sugerido pela Professora Dra. Dalva de Faria do IQ/USP, para uma melhor elucidação dos resultados observados. Seria importante realizar um estudo por Surface Enhanced Raman Spectroscopy (SERS), que é uma técnica de superfície mais sensível e que resulta na ampliação da dispersão Raman por absorção de moléculas isoladas. O fator de amplificação desta técnica pode ser da ordem de $10^{-4}$ e $10^{-6}$ e também $10^{-8}$ e $10^{-14}$ para alguns sistemas. Esta amplificação do sinal poderá melhorar os resultados em um fator de igual proporção.

\subsubsection{Teste quantitativo}

Como um futuro trabalho, poderá ser realizado também em parceria com o Departamento de Nanociências e Materiais Avançados da Universidade Federal do $\mathrm{ABC} / \mathrm{UFABC}$ para processamento dos cálculos quantitativos com um volume maior de amostras sanguíneas. 
Nesse futuro teste haverá a avaliação das diferenças de tons e tamanhos das manchas de sangue produzidas nos halos por diferentes tipos de sangue de pacientes com $\mathrm{Hb} \mathrm{AA}, \mathrm{Hb}$ AS e Hb SS.

Por conseguinte, com um maior número de amostras de pacientes portadores ou não da doença, os halos produzidos serão digitalizados e a barra de escala de medição do centro para a periferia do halo será definida podendo-se fazer uma quantificação e avaliação estatística dos mesmos. 
$7 \quad$ ANEXO

Autorização da comissão de ética em pesquisa - CONEP

Plotoforma MINISTÉRIO DA SAÚDE - Conselho Nacional de Saúde - Comissão Nacional de Ética em Pesquisa - CONEP Brasil

FOLHA DE ROSTO PARA PESQUISA ENVOLVENDO SERES HUMANOS

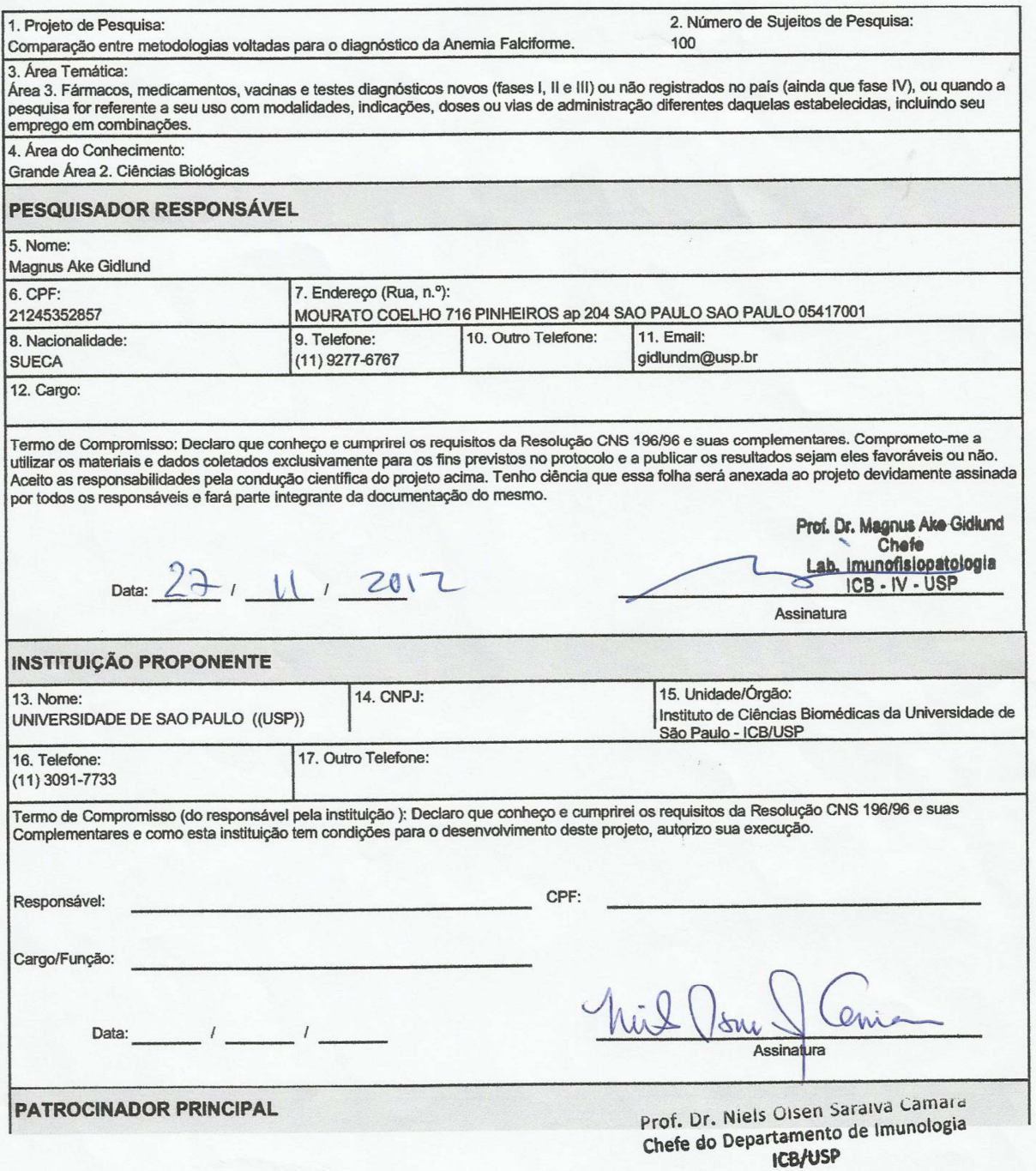

